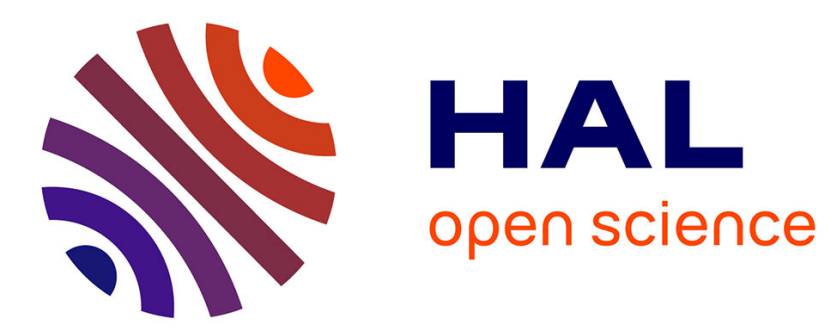

\title{
Tail events, emotions and risk taking
}

Brice Corgnet, Camille Cornand, Nobuyuki Hanaki

\section{To cite this version:}

Brice Corgnet, Camille Cornand, Nobuyuki Hanaki. Tail events, emotions and risk taking. 2020. halshs-02613344

\section{HAL Id: halshs-02613344 \\ https://shs.hal.science/halshs-02613344}

Preprint submitted on 20 May 2020

HAL is a multi-disciplinary open access archive for the deposit and dissemination of scientific research documents, whether they are published or not. The documents may come from teaching and research institutions in France or abroad, or from public or private research centers.
L'archive ouverte pluridisciplinaire HAL, est destinée au dépôt et à la diffusion de documents scientifiques de niveau recherche, publiés ou non, émanant des établissements d'enseignement et de recherche français ou étrangers, des laboratoires publics ou privés. 
UMR 5824

93. chemin des Mouilles 69130 Ecully - France

Maison de l'Universite, Bâtiment B 10, rue Trefilerie 42023 Saint-Etienne cedex $02 \cdot$ France http://www.gate.cnrs.fr gate@gate.cnrs.fr

\title{
Tail events, emotions and risk taking
}

\section{Brice Corgnet, Camille Cornand, Nobuyuki Hanaki}

\begin{abstract}
:
Recent works have shown how tail events could account for financial anomalies such as the equity premiumpuzzle. These models do not explore, however, why investors would discount tail risk so heavily. We take on this challenge by designing a novel tail-event experiment to assess both investors' behavioral and physiological reactions. We show that investors who observe the tail event without suffering losses tend to decrease their pricing of the asset subsequently. By contrast, loss-averse investors who suffer tail losses tend to increase their bids. This response is especially pronounced for those who exhibit a strong emotional response to tail losses. This demonstrates the key role played by emotions in influencing investors' response to tail events. Finally, investors who exhibit high anticipatory arousal, as measured with electrodermal activity, posted lower bids and were less likely to suffer tail losses and go bankrupt. They also achieved higher earnings when tail events occurred frequently. This finding contrasts with the common view that investors should silence their emotions.
\end{abstract}

\section{Keywords:}

tail events, emotions and risk

JEL codes:

C91, G41, D87, D91

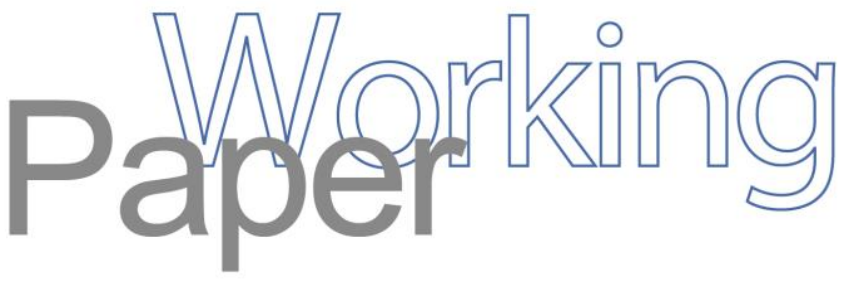




\title{
TAIL EVENTS, EMOTIONS \& RISK TAKING*
}

\author{
Brice Corgnet $^{\dagger} \quad$ Camille Cornand ${ }^{\ddagger} \quad$ Nobuyuki Hanaki ${ }^{\S}$
}

May 19, 2020

\begin{abstract}
Recent works have shown how tail events could account for financial anomalies such as the equity premium puzzle. These models do not explore, however, why investors would discount tail risk so heavily. We take on this challenge by designing a novel tail-event experiment to assess both investors' behavioral and physiological reactions. We show that investors who observe the tail event without suffering losses tend to decrease their pricing of the asset subsequently. By contrast, loss-averse investors who suffer tail losses tend to increase their bids. This response is especially pronounced for those who exhibit a strong emotional response to tail losses. This demonstrates the key role played by emotions in influencing investors' response to tail events. Finally, investors who exhibit high anticipatory arousal, as measured with electrodermal activity, posted lower bids and were less likely to suffer tail losses and go bankrupt. They also achieved higher earnings when tail events occurred frequently. This finding contrasts with the common view that investors should silence their emotions.
\end{abstract}

Keywords: tail events, emotions and risk.

JEL codes: C91, G41, D87, D91.

\section{Introduction}

Mainstream finance theory is designed to apply in 'normal times', that is, when asset returns fall into a standard range of values. This statement is exemplified by the use of Gaussian distributions and quadratic utility functions in portfolio theory (see e.g., Markowitz, 1952; Tobin, 1958; Sharpe, 1964; Lintner, 1965) and option pricing (Black and Scholes, 1973). Although infrequent, tail events can wipe out financial gains accumulated in normal times (e.g., Taleb, 2007; Barberis, 2013a; Shiller, 2015; Aliber and Kindleberger, 2017), as is illustrated by the extreme drop in stock market indices worldwide in March, 2020. On the $16^{\text {th }}$

\footnotetext{
${ }^{*}$ This research has benefited from the financial supports from the Japanese Society for Promotion of Sciences (Project number 18K19954) and from the French National Research Agency (ANR) under an ORA-Plus project "BEAM" (ANR-15-ORAR-0004 ), and was performed within the framework of several Programme Investissements d'Avenir under IDEXLYON (ANR-16-IDEX-0005) of Université de Lyon (project INDEPTH), LABEX CORTEX (ANR-11-LABX-0042) of Université de Lyon (ANR-11-IDEX-007), and UCAJEDI (ANR-15-IDEX-01) of Université Côte d'Azur (project UCAinACTION). We would like to thank Mateus Joffily for useful discussions and assistance with physiological recordings, Quentin Thévenet for the design of the computer software and for his assistance during experimental sessions, and Mark DeSantis for useful feedback. The design of the experiment reported in this paper has been approved by the IRB of INSERM (\#18-493) in May 2018.

${ }^{\dagger}$ Univ Lyon, emlyon business school, GATE UMR 5824, F-69130 Ecully, France. Email: corgnet@em-lyon.com

‡Univ Lyon, CNRS, GATE UMR 5824, F-69130 Ecully, France. Email: cornand@gate.cnrs.fr

§Institute for Social and Economic Research, Osaka University. Email: nobuyuki.hanaki@iser.osaka-u.ac.jp
} 
of March, the S\&P500 index lost almost 12\%, which is the third largest drop in the index history and the largest daily decline in more than 30 years.

Numerous works in economics and finance have shown that the excess returns of stocks relative to bonds (i.e., 'equity premium puzzle') could be accounted for by incorporating tail events in the pricing of assets (e.g., Rietz, 1988; Barro, 2006, 2009; Bollerslev and Todorov, 2011; Gabaix, 2012; Kelly and Jiang, 2014; Bollerslev et al., 2015; Andersen et al., 2019). Bollerslev and Todorov (2011) created an 'Investor Fears index' by estimating the risk associated to jumps or discontinuities in the pricing of options, and showed that pricing fear of tail events using their index could account for a substantial part of the equity premium puzzle. Using firm-level prices instead of option prices, Kelly and Jiang (2014) also found that tail risk had a substantial impact on asset prices.

Our approach differs from the above-mentioned works on tail risk by focusing on investors' reaction to tail events rather than on the pricing of potential rare events. Our work is the first to study investors' behavioral and emotional reaction to non-hypothetical tail events. ${ }^{1}$ This change of focus is motivated by the fact that tail events are likely to generate an emotional response which is difficult to assess ex-ante (e.g., Gilbert and Wilson, 2007). Because tail events are rare, their occurrence will generate surprise which is a key driver of emotional arousal (see Joffily and Coricelli, 2013) and one of the six basic emotions (Ekman, 1999). ${ }^{2}$ Such emotional reaction can interfere with expected utility calculations as is put forth by the proponents of the 'risk-as-feelings' hypothesis (Loewenstein et al., 2001) or the 'affect heuristic' (Slovic et al., 2007). Emotions experienced at the moment of making a decision will affect a person's evaluation of a prospect. This is the reason why Camerer et al., $(2005$, p. 46) urge scholars to incorporate emotions in their study of risky choices in economics and finance:

"We are skeptical of whether any theory that fails to incorporate the affective dimensions of risk will be capable of shedding much light on such important phenomena as stock market booms and busts, the ubiquity of gambling (e.g., slot machines revenues dwarf revenues from movies), and the vicissitudes of public responses to threats as diverse as terrorism and global warming."

By contrast, in consequentialist theories of decision-making such as Expected Utility Theory (EUT, henceforth) or Prospect Theory (PT, henceforth), emotions do not impact decisions. Instead, emotions

\footnotetext{
${ }^{1}$ Kunreuther and Pauly (2018) study the effect of self-reported emotions on the purchasing of insurance against natural disasters in a hypothetical experiment conducted online. They show that emotions can explain changes in insurance purchasing behavior as most participants decided to get insured after observing a loss. Participants who decided to get insured and observed a bad outcome did not cancel their insurance.

${ }^{2}$ Suprise can be associated with other emotions like anger, fear or hope.
} 
are seen as inconsequential side effects of decisions (Loewenstein et al., 2001). The interplay between the cognitive assessment of prospects and emotions renders the study of investors' reaction to tail events especially challenging. But, the empirical study of the moderating role of emotions on decision making is a crucial step forward because it can help improve the predictive power of standard decision-making models (Loewenstein et al., 2001; Lerner et al., 2015).

Besides the role of emotions, another challenge in the study of tail events is that data are both scarce and idiosyncratic. For example, in finance, tail events can be identified as major market crashes all of which possess specific characteristics (Aliber and Kindleberger, 2017). The study of the reaction of investors to tail events thus seems to require a 'tail-event factory', enabling us to credibly and consistently produce unlikely events. We opted for developing such a device in a controlled laboratory environment, which allowed us to precisely assess the emotional arousal of participants using physiological recordings (i.e., electrodermal activity) and thus the impact of emotions on the evaluation of investment prospects (Critchley et al., 2000; Christopoulos et al., 2019). ${ }^{3}$

In our design, individuals had to bid repeatedly, using a standard Becker, DeGroot and Marschak (1964) (BDM, henceforth) mechanism, for a financial asset that delivered a small positive reward (either 10ф, 20ф, $30 \notin, 40 \notin$ or $50 \notin)$ in more than $99 \%$ of the cases and a large loss $(1,000 \notin)$ otherwise. The loss event was both very unlikely $(0.66 \%)$ and substantial enough to possibly wipe out accumulated earnings. Because we did not want to set the sequence of tail events prior to the experiment to ensure the credibility of the procedure, our experiment consisted of a large number of periods (300). Furthermore, we randomly selected one of the participants before the experiment started to make the draws. This feature extends previous laboratory setups using computerized draws (Barron and Erev, 2003; Hertwig et al., 2004; Erev, 2007; Erev et al., 2017, Payzan-LeNestour, 2018).

In order to assess the drivers of individuals' reactions to tail events as well as to isolate the specific impact of emotions on investors' bids, we collected extensive individual information to be used as controls in our analyses. These include risk, loss and ambiguity attitudes as well as personality traits, cognitive and Bayesian updating skills. This led us to conduct a two-day experiment in which we elicited individual characteristics on the first day and conducted the tail-event experiment on the second day. To make the monetary loss associated with the tail event especially painful, we asked participants to use the fixed wage they earned in the first-day survey $(12 €)$ for their investment decisions in the second day (see Thaler

\footnotetext{
${ }^{3}$ While Payzan-LeNestour (2018) also developed a tail-event software, her aim was to study individuals' ability to learn whether they were facing an environment in which tail losses were either frequent ( $16 \%$ of the times) or rare $(1 \%)$.
} 
and Johnson, 1990, and Corgnet et al., 2015). It follows that investors going bankrupt in the second-day experiment would lose the money they earned in the first day.

Using model simulations with EUT and PT investors, we derive a set of predictions regarding individuals' reactions to tail events in the experiment. Our first hypothesis states that investors, who experience tail events without suffering losses, will update the probability of tail events upwards and decrease their bids after observing a tail event. We show that this effect is especially pronounced when people exhibit a 'recency bias', thus relying on small samples to update the likelihood of tail events (Tversky and Kahneman, 1973, 1974; Rabin, 2002; Plonsky et al., 2015). Relatedly, prior research has evoked the 'availability bias', according to which people estimate the probability of occurrence of an event by the ease with which relevant instances come to mind, to explain beliefs updating of low-frequency events (e.g., Tversky and Kahneman, 1973, 1974; Kunreuther et al., 1978; Barberis, 2013a). People who use the availability heuristic tend to underweight the probability of a tail event until they observe it, after which, they tend to overweight it (e.g., Barberis, 2013a). Our experimental findings support our first hypothesis, as participants were more likely to decrease their bids after observing, yet not suffering, a tail event compared to a non-tail event. In addition, this effect seemed more pronounced for participants exhibiting availability or recency biases.

Our second hypothesis puts forth that PT investors, who suffer tail losses, will take on more risks, thus triggering an increase in bids. Our experimental results support this prediction because bids were more likely to increase after incurring tail losses, and this effect was especially pronounced for those investors who exhibit high levels of loss aversion.

Because we are interested in the effect of emotions on investors' reactions to tail events, we also study the extent to which emotional arousal, as measured with electrodermal activity, could impact the previous findings. By extending the model to allow investors to exhibit anticipatory arousal before tail events occured as well as display emotional reactions after they occured, we derive three emotion-related hypotheses. In Hypothesis 3, we posit that risk seeking is magnified by investors' emotional response to tail losses. In line with this hypothesis, we found that investors who showed a stronger emotional response to tail losses, were those who were more likely to increase their bids. In Hypothesis 4, we also put forward that fear (hope) will lead investors to decrease (increase) their bids after observing, yet not suffering, tail events. Our experimental data provided suggestive evidence for this hypothesis. Finally, we show that, in line with Hypothesis 5, investors exhibiting high anticipatory arousal posted lower bids and, thus, were less likely to suffer tail losses and go bankrupt. In experimental sessions in which numerous tail events occurred, these 
traders ended up earning more than those who exhibited low anticipatory arousal.

Our findings emphasize that emotions may be beneficial to investors, thus challenging the widespread belief that they should be kept under control (Shefrin, 2000; Lo and Repin, 2002; Lo 2019). More generally, our work highlights the complexity of the interaction between emotions and decision-making. Any regulatory attempt to tame emotional responses in the face of tail events should take this complexity into account to limit the unintended consequences.

\section{Design}

We designed an incentivized experiment that allows us to observe participants' reactions to tail events. We invited participants for two sessions taking place on two different days. In Day 1, participants earned money by responding to a survey regarding various psychological and cognitive characteristics (Section 2.3), and in Day 2 participants played a repeated investment task while physiological measures were recorded (Sections 2.1 and 2.2).

\subsection{Investment task}

We elicited participants' willingness to pay for an asset that involves a tail risk using the BDM method. At the beginning of each of the 300 periods, participants had to bid for a financial asset that delivered a small positive reward (either $10 \notin, 20 \notin, 30 \notin, 40 \notin$ or $50 \notin$ ) in $99.34 \%$ of the cases and a large loss $(1,000 \notin)$ otherwise. The bid (any integer between 0 and 50) in each period was compared to a price (also an integer) randomly drawn from a uniform distribution between 1 and 50. If the bid of participants was greater than or equal to the price, they paid the price and received the asset, otherwise they did not purchase the asset.

At the end of each period, a feedback screen showed the color that was drawn, the earnings for the current period as well as cumulated earnings. Cumulated earnings were equal to the initial endowment, which is equal to Day 1 fixed wage $(1,200 \notin)$, plus the gains and losses from buying the asset in previous periods.

The tail event was highly unlikely $(0.66 \%)$ but triggered losses which were as large as $83.3 \%$ of Day 1

fixed wage. As a result, participants would typically go bankrupt when suffering the tail event twice. The tradeoff in selecting the probability of the tail event occurring is that it must be high enough to ensure most participants would experience it while being rare enough to be qualified as a tail event. Although no formal definition regarding what should be the frequency of tail events exists, we opted for picking a 
number below $1 \%(0.66 \%)$, which is smaller than typical experiments studying the pricing of tail risks. ${ }^{4}$

To make the monetary loss associated with the tail event especially meaningful, we asked participants to invest the fixed wage they earned in Day 1 during the investment task. In addition, participants were given a loan of $1,000 \notin$ for liquidity reasons, which had to be repaid at the end of the experiment. ${ }^{5}$ This loan ensured that participants would have enough cash to bid for the asset even after tail losses had been incurred, thus allowing us to study investors' reaction to tail events while abstracting from potential liquidity constraints. However, if the current wealth of participants (including the loan) was no longer sufficient to repay the loan, they would go bankrupt. In that case, participants could not purchase the asset anymore and had to wait until the end of the session while provided with Internet access. Investors who went bankrupt lost the fixed wage they earned on Day 1 and were only rewarded a 5-euro show-up fee. ${ }^{6}$

Because participants can lose all their endowment when a tail event occurs, participants might believe the experimenter is purposefully engineering the draws to ensure tail events would occur, thus reducing participants' earnings and lowering the cost of the experiment. To make it clear to the participants that the sequence of draws was random and thus unpredictable, we adopted the following hand-run procedure. Before participants read the instructions, we showed them a transparent box containing 302 tokens of 6 different colors, each of which was associated with a payoff for the asset (blue token $=10 \notin$, red token $=$ $20 \notin$, orange token $=30 \notin$, green token $=40 \notin$, purple token $=50 \notin$, yellow token $=-1,000 \phi)$. There were 60 tokens of each color, except for two yellow tokens. Once everyone had seen the tokens, we told participants we were taking a picture of the box that would be displayed on their screens during the experiment. ${ }^{7}$ By observing this picture during the experiment, participants could form an estimate of the frequency of occurrence of each token (see screenshot in Online Appendix I.4). The distribution of tokens was thus not fully known by participants so as to allow for learning during the experiment.

Next, one participant, the picker, was randomly selected and escorted to a separate room. The picker was asked to put all the tokens of the transparent box in an opaque bag and draw the tokens with replacement. The picker entered the token draws on a computer and on a separate sheet of paper in real time. This sheet of paper was signed by the picker upon the completion of the task, and shown to all other participants

\footnotetext{
${ }^{4}$ Existing studies usually consider tail frequencies equal to 1\%, 5\% or 10\% (e.g., Barron and Erev, 2003; Hertwig et al., 2004; Erev, 2007; Erev et al., 2017). For an early survey on choices with low probability, high-consequence events and on their impact on policymaking, see Camerer and Kunreuther (1989). Camerer (1987) and Kluger and Wyatt (2004) also review the biases involved in such choices as well as their impact on markets.

${ }^{5}$ This design feature is inspired from Plott and Sunder $(1982,1988)$.

${ }^{6}$ There is limited liability in our experiment because bankrupt participants did not repay the loan in full. On average, they repaid about $80 \%$ of its value.

${ }^{7}$ Actually, a photograph of the box was taken prior to the first experimental session so that the picture displayed on participants' screens was exactly the same in all sessions.
} 
at the end of the experiment to further ensure the credibility of the procedure. The picker did not know the instructions of the investment task to avoid any cheating attempts or any retaliation by peers. ${ }^{8}$ The picker was paid a fixed amount of 15 euros, but incurred a 5-euro penalty if the task was not completed within 1 hour to ensure timely completion of the experiment. ${ }^{9}$ During the task, one of the experimenters closely monitored the picker to make sure the procedure was followed.

Among the fifteen sessions we conducted, we had an average of two tail events per session including a session without any tail event and four sessions with four. ${ }^{10}$ The distribution of tail events for each session is reported in Appendix A (Figure A.1).

An English translation of the instructions for the investment task and for the drawing task is reported in Online Appendices I.3.1 and I.3.2.

\subsection{Physiological measurement}

Our experimental design allowed us to precisely assess the emotional arousal of participants using physiological tools measuring electrodermal activity during the investment task (Critchley et al., 2000; Boucsein, 2012; Christopoulos et al., 2019). One of the experimenters placed electrodes on participants' second phalanx of the index and middle fingers using a velcro strap and isotonic gel. Another experimenter checked the quality of the recordings before the experiment could start. Setting up the physiological equipment took about 20 minutes on average.

This is a critical part of our design because it allows us to study the moderating role of emotions on decision making in the presence of tail events. After a stimulus is observed, the electrodermal activity needs time to rise and this is referred to as latency (see Figure A.2 in Appendix A for the typical shape of an event-related electrodermal activity). Latency is on average about 4 seconds. In the following seconds, the signal rises until it reaches a peak. In the absence of further stimulation, the signal recovers its baseline (pre-stimulus) level. In our setup, we recorded electrodermal responses to three types of stimuli: $i$ ) the decision screen is shown to participants, ii) a decision is made, and iii) the earnings for the period is shown on the screen. We will refer to the first measurement as anticipatory arousal following the work of Bechara et al., (1997). The second and third measurements are defined as decision and feedback arousal. ${ }^{11}$

\footnotetext{
${ }^{8}$ The other participants knew the picker did not know the instructions for the investment task.

${ }^{9}$ This penalty was never implemented. After the picker started his or her task, one of the experimenters installed the physiological tool on the remaining participants (see Section 2.2) who then read the instructions of the investment task. Because the picker started his or her task before the investment task, the potential issue of the picker drawing tokens too slowly never occurred.

${ }^{10}$ This empirical distribution is consistent with random draws because there were exactly two yellow tokens in the bag.

${ }^{11}$ In Section 4, we use feedback and anticipatory arousal measurements leaving aside decision arousal. However, similar results can be obtained using decision instead of anticipatory arousal as the two measurements are highly correlated.
} 
To ensure sufficient time elapsed in between stimuli, we inserted a 4-second waiting screen after a decision was made and after the end-of-period feedback was received. ${ }^{12}$ Each period, participants were given 10 seconds to make a decision, except for the first and second periods for which they had 30 and 20 seconds, respectively. ${ }^{13}$ Our metric of interest is the amplitude of the signal as computed using the Matlab routine developed in Joffily (2018)'s electrodermal activity toolbox and which is equal to the peak of the physiological response measured in microsiemens (see Figure A.2).

Breaban and Noussair (2018) considered an alternative physiological measure of emotions in a standard experimental asset market with bubbles (Smith et al., 1988) by assessing traders' emotional state (happiness, surprise, anger, disgust, sadness or fear) using a face-reading software. As an alternative to physiological measurements of emotions, surveys are particularly popular. Kunreuther and Pauly (2018) elicited emotions releasing questionnaires to participants in a hypothetical insurance-purchasing experiment conducted online. In contrast to Breaban and Noussair (2018) and Kunreuther and Pauly (2018), we focused on eliciting emotional arousal, that is the magnitude of the emotional response and not its valence, that is whether the emotional response is positive or negative. We did so for three reasons. First, it seems quite straightforward that the valence associated with tail losses is negative. Second, we did not want the elicitation of emotional valence to interfere with the behavior in the investment game and with our physiological recordings. Third, eliciting emotional valence would have lengthened an already long experiment. Alternatively, we decided to use the HEXACO personality test (Ashton and Lee, 2009), which was conducted on Day 1 to inform us about participants' inclination toward certain emotions such as fear, anger or hope.

\subsection{Survey}

In Day 1, we collected extensive individual information regarding risk, loss and ambiguity attitudes as well as personality traits, cognitive skills, Bayesian updating and demographic data. We also elicited estimations of the percentage of yellow and orange tokens in the photograph of the box of tokens that was displayed on participants' screens during the investment task on Day 2. ${ }^{14}$

\footnotetext{
${ }^{12}$ Regarding the decision screen stimulus, the quality of the electrodermal recording was ensured by the fact that decisions were made on average after 11 seconds (in the first five periods, which are used to measure anticipatory arousal in Section 4.4) and after 7 seconds overall. In the first five periods, no decision was made in the first four seconds.

${ }^{13} \mathrm{~A}$ timer on the screen indicated the time participants had to enter a price using a cursor. If participants did not enter a price on the screen and validate their decision on time, the number indicated by the cursor was selected. To prompt participants to make a decision each period, the default value on the cursor was 50 .

${ }^{14}$ To avoid interfering with behavior in the investment task and with physiological recordings and also because of time constraints, we did not elicit beliefs over the 300 periods of the investment task.
} 
An English translation of the 12 blocks of tests, as well as descriptive statistics are reported in Online Appendix I.1. All the tasks were computerized and the duration of the survey was about 1 hour. To limit attrition, participants were only paid the show-up fee $(5 €)$ at the end of Day 1 sessions and thus needed to come back on Day 2 to collect their Day 1 earnings, which consisted of a fixed wage of $12 €$ and a variable pay depending on their decisions in some of the tests (4.6€ on average).

\subsection{Protocol}

Between November 2018 and February 2019, we invited a total of 154 participants from which 109 showedup on Day 1, from a participant pool of more than 2,500 students in Lyon, France. Half of the participants were males and the average age of participants was 21.6 years old. On Day 2, 83.5\% of the participants who completed Day 1 showed up. ${ }^{15}$ We conducted a total of 15 sessions on Day 2, 11 of which with 6 investors and the rest with 5 investors, which amounted to a total of 86 decision makers. ${ }^{16}$ Day 1 sessions lasted for 1 hour and Day 2 sessions for 3.5 hours. Average earnings for the two-day experiment were 38 euros, including a 5 euros show-up fee for each day.

\section{Model \& hypotheses}

To derive a set of hypotheses regarding investors' reaction to tail events, we consider a model that encompasses EUT and PT specifications.

\subsection{Main model}

We assume that each investor $i$ is choosing her bid $b_{t}^{i}$ in period $t$ given her belief $B_{c, t}^{i}$ regarding the probability that color $c$ is drawn in period $t$, where $c \in\{0,1,2,3,4,5\}$ and $c=5$ stands for the yellow color (that is, the tail event). An investor $i$ selects a bid so as to maximize the following utility function:

$$
b_{t}^{i^{*}}=\operatorname{argmax}_{b_{t}^{i} \in[0,50]} \sum_{r_{t}=1}^{b_{t}^{i}} \frac{1}{50} \sum_{c=0}^{5} B_{c, t}^{i} u^{i}\left(w_{t}^{i}-r_{t}+v(c), R_{t}^{i}\right)+\sum_{r_{t}=b_{t}^{i}+1}^{50} \frac{1}{50} u^{i}\left(w_{t}^{i}, R_{t}^{i}\right),
$$

where $v(c)$ is the payoff associated to drawing color $c$. The variable $r_{t}$ refers to the random integer (drawn uniformly between 1 and 50) used in the BDM mechanism that determines whether the investor buys the

\footnotetext{
${ }^{15}$ Out of the 91 participants who came back, 86 played the role of investors whereas 5 were assigned the role of pickers. The remaining 10 pickers were recruited separately for Day 2 sessions.

${ }^{16}$ Due to the technical complexity of setting up the physiological tool, we conducted one session at a time.
} 
asset or not. We also denote by $w_{t}^{i}$ the accumulated level of wealth of investor $i$ up to period $t$ and by $R_{t}^{i} \geq 0$ the reference wealth in period $t$.

We then consider the following power utility function which has received large empirical support (e.g., Stott, 2006):

$$
u^{i}\left(w_{t}^{i}, R_{t}^{i}\right)=\left\{\begin{array}{cc}
\left(w_{t}^{i}-R_{t}^{i}\right)^{\alpha^{i}}, & \text { if } w_{t}^{i} \geq R_{t}^{i} \\
-\lambda^{i}\left[-\left(\max \left\{w_{t}^{i}, 0\right\}-R_{t}^{i}\right)\right]^{\alpha^{i}}, & \text { otherwise }
\end{array}\right.
$$

where $\alpha^{i}>0$ characterizes risk attitudes and the term $\max \left\{w_{t}^{i}, 0\right\}$ appears in lieu of $w_{t}^{i}$ because of the limited liability of the participants in our experiment. In the EUT framework, the loss aversion parameter $\left(\lambda^{i}\right)$ and the reference wealth $\left(R_{t}^{i}\right)$ are set to 0 . In the PT framework, we assume $\lambda^{i}>1$. We consider that the reference wealth is determined by the original level of wealth $\left(w_{0}^{i}\right)$ which, in our experiment, can be set equal to the fixed wage earned in Day $1(1,200 \notin)$.

To determine how investors update their beliefs, we rely on Bayes' rule. This is further motivated by the findings of Payzan-LeNestour (2018), who showed that people use Bayesian updating in an environment in which they learnt about the likelihood of tail events. In particular, we assume a conjugate prior for the multinomial distribution associated to the probability of occurrence of each color. The conjugate prior for the multinomial distribution is the Dirichlet distribution, $\operatorname{Dir}\left(\eta_{0}^{i}, \eta_{1}^{i}, \eta_{2}^{i}, \eta_{3}^{i}, \eta_{4}^{i}, \eta_{5}^{i}\right)$, where $\frac{\eta_{c}^{i}}{\eta^{i}}$ represents the prior for the probability of occurrence of color $c$ and $\eta^{i}=\sum_{c=0}^{5} \eta_{c}^{i}$ captures the overall weight assigned to prior probabilities. We denote the sample evidence regarding the probability of occurrence of the respective colors until period $t$ by $s_{t}^{i}=\sum_{c=0}^{5} \sum_{j=1}^{t}\left(\rho^{i}\right)^{t-j} s_{c, j}$, where $s_{c, j}$ is a dummy variable that takes value one if color $c$ is observed in period $j$ and value zero otherwise. We introduce the parameter $\rho^{i} \in[0,1]$ so as to capture a recency bias in the probability updating of investor $i$. Perfect Bayesian updating corresponds to $\rho^{i}=1$, in which case all the past realizations are used in updating the subjective belief. However, investors might rely on small samples for updating their beliefs $\left(\rho^{i}<1\right) .{ }^{17}$ In our model, the recency and availability biases are closely related because they both lead people to overweight the occurrence of tail events after observing them. The belief of investor $i$ in period $t$ is thus computed as follows:

$$
B_{c, t}^{i}=\frac{1}{\eta^{i}+s_{t}^{i}}\left(\eta_{c}^{i}+\sum_{j=1}^{t}\left(\rho^{i}\right)^{t-j} s_{c, j}\right)
$$

We simulate our model using the parameters of the experiments (see Online Appendix II for further

\footnotetext{
${ }^{17}$ There is mounting evidence that people rely on small samples and overweight salient information (Tversky and Kahneman, 1973, 1974; Rabin, 2002; Plonsky et al., 2015).
} 


\section{Tail event observed but not suffered}
(a) EUT
(b) PT
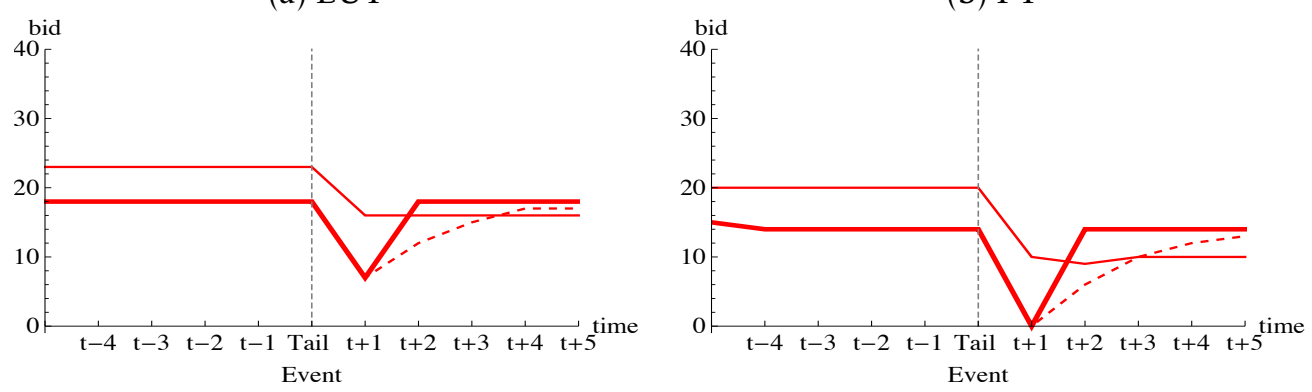

$\underline{\text { Tail event suffered }}$

(c) EUT

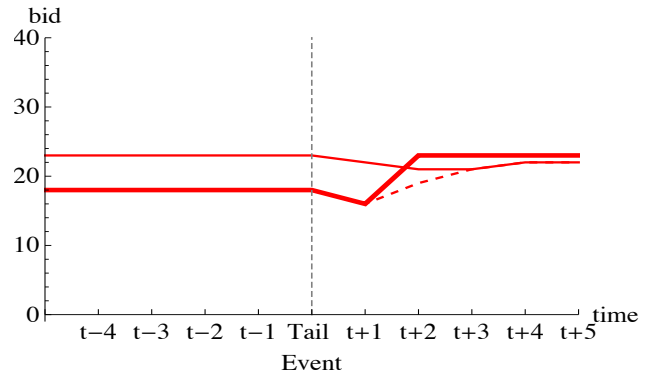

(d) PT

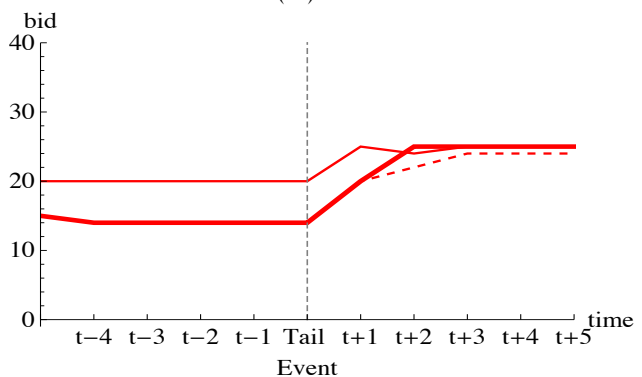

Figure 1: Upper panels. Dynamics of bids around the tail event when it was not suffered. Lower panels. Dynamics of bids around the tail event when it was suffered. (a) and (c) are for EUT investors with $\alpha^{i}=0.75$ and (b) and (d) are for PT investors with $\alpha^{i}=0.75$ and $\lambda^{i}=1.5$. In all panels, results for three values of $\rho^{i}$ : 0 (thick), 0.5 (thin dashed) and 1 (thin solid) are shown.

details on the simulations). In the model simulations reported below, we assume the prior belief of the tail event, which we denote $\pi^{i}=\frac{\eta_{5}^{i}}{\eta^{i}}$, is $1 \%$ while the weight on the prior $\eta^{i}$ is 100 , and investors believe all remaining payoffs are equally likely. ${ }^{18}$ Furthermore, we consider the case of a risk-averse EUT investor $\left(\alpha^{i}=0.75\right)$ and a PT investor with $\lambda^{i}=1.5$ and $\alpha^{i}=0.75$, unless noted otherwise. In Online Appendix III, we conduct numerous robustness checks where we consider alternative parameter values of our model (i.e., $\left.\alpha^{i}, \lambda^{i}, \pi^{i}, \eta^{i}\right)$. These results confirm the findings summarized in each hypothesis.

The upper panels of Figure 1 display the evolution of bids for the case in which investors observed the tail event without incurring tail losses under EUT (panel (a)) and PT (panel (b)) for three values of $\rho^{i}: 0$ (thick), 0.5 (thin dashed) and 1 (thin solid).

Our model implies that observing the tail event will lead investors to update their beliefs about its occurrence upwards compared to a case in which no tail event is observed. When tail events are observed without being suffered, they tend to depress bids whether we consider EUT or PT investors (see upper

\footnotetext{
${ }^{18}$ In the Day 1 survey, the median prior belief of participants regarding the occurrence of a tail event was $1.2 \%$.
} 
panels in Figure 1). The decrease in bids also appears to be magnified by the presence of a recency bias $\left(\rho^{i}<1\right)$ (thick and thin dashed lines in the upper panels of Figure 1). This leads us to the first hypothesis.

Hypothesis 1. Tail Events and Bids Under EUT \& PT, investors who observe but do not suffer a tail event are more likely to reduce their bids compared to investors who observe a nontail event. This effect is especially pronounced for investors with a high level of recency or availability bias.

The lower panels of Figure 1 display the evolution of bids for the case in which the risk averse $\left(\alpha^{i}=0.75\right)$ investor observed the tail event and incurred its loss. Under EUT, the decline in wealth which follows tail losses causes the limited liability assumption to bind, thus partly offsetting the depressing effect of updated beliefs on bids (see Figure 1 panel (c)). More strikingly, under PT, investors who incurred tail losses tend to become more risk seeking as they are dragged into the loss domain (Kahneman and Tversky, 1979; Tversky and Kahneman, 1992). This leads them to increase rather than decrease their bids after suffering a tail event. Panel (d) of Figure 1 shows that PT investors are more likely to increase their bids after experiencing a tail than a non-tail event. This leads us to the second hypothesis.

Hypothesis 2. Tail Losses and Bids Under PT, investors who suffer a tail event are more likely to increase their bids compared to investors who experience a non-tail event.

The first two hypotheses capture the reaction of investors to tail events in the absence of emotional considerations. We now turn to the study of the moderating role of emotions on risk taking, which is at the center of the 'risk-as-feeling' hypothesis (see Figure 3, p. 270, in Loewenstein et al., 2001). ${ }^{19}$

\subsection{Model with emotions}

We will consider several mechanisms by which emotions can impact investors' reactions to tail events by affecting either their utility (Section 3.2.1) or their beliefs (Section 3.2.2). We also study the relation between anticipatory arousal and financial gains (Section 3.2.3).

\footnotetext{
${ }^{19}$ This hypothesis is supported by extensive research in neuroscience showing how emotional centers of the brain, such as the nucleus accumbens, the anterior insula or the amygdala, are involved in risky decisions (Bechara et al., 1997; Bechara and Damasio, 2005; Camerer et al., 2005; Kuhnen and Knutson, 2005; Preuschoff et al., 2006, 2008; Knutson and Bossaerts, 2007; Knutson et al., 2008). However, Christopoulos et al., (2009) do not report insula activation in decisions under risk; they emphasize the role of the inferior frontal gyrus. Research using physiological correlates of emotional arousal such as electrodermal and cardiovascular activity have also identified the crucial role of emotions in decision making under risk (Damasio, 1994; Lo and Repin, 2002). Electrodermal activity has been linked to the brain activation of emotional centers such as the amygdala (Boucsein, 2012).
} 


\subsubsection{Anger and losses}

Shefrin (2000, p. 107) argues that investors are prone to 'get-evenitis' which is defined as "the difficulty people experience in making peace with their losses". This behavior is also key to explain the disposition effect according to which investors are reluctant to sell stocks at a loss (Shefrin and Statman, 1985; Odean, 1998). Well-known cases of traders such as Nick Leeson or Jérôme Kerviel who increased their positions instead of exiting the market after incurring considerable losses have also been interpreted as examples of 'get-evenitis' (see Lo, 2019).

In PT, investors can attenuate risk seeking in the loss domain by swiftly adjusting their reference level of wealth to the new circumstances. We consider the following specification of the dynamics of the reference wealth level:

$$
R_{t}^{i}=\omega^{i} R_{t-1}^{i}+\left(1-\omega^{i}\right) w_{t}^{i}
$$

where $R_{0}^{i}=w_{0}^{i}=1,200$ which is the initial endowment of investors in the experiment, and $\left(1-\omega^{i}\right)$ captures the investor's inclination to make peace with losses. When $\omega^{i}=1$, the reference wealth level remains equal to the initial level of wealth as was assumed in the main model of Section 3.1. By contrast, when $0 \leq \omega^{i}<1$, investors adjust their reference wealth level so as to partly reflect current wealth. In particular, when $\omega^{i}=0$, investors suffering tail losses would immediately adjust their reference wealth to the current level of wealth thus immediately 'making peace with their losses'. This will prevent investors from suddenly exhibiting risk-seeking behavior after incurring tail losses. ${ }^{20}$

In Figure 2, we simulate bids for a PT investor $\left(\lambda^{i}=1.5\right.$ and $\left.\alpha^{i}=0.75\right)$ for four different levels of $\omega^{i}$. Panels (a) and (b) show the results in the absence or presence of a recency bias. In the case in which investors immediately 'make peace with their losses' ( $\omega^{i}=0$, thick solid lines), they tend to decrease their bids even after tail losses have been incurred. This is the case because the depressing effect of tail events on beliefs dominates the positive effect on bids associated with risk seeking in the loss domain. The more sluggish investors are to adjust their wealth level (i.e., the higher $\omega^{i}$ ), the more likely bids will increase after tail losses.

The inability of investors to make peace with their losses $\left(\omega^{i}>0\right)$ is likely to be driven by an emotional reaction to losses (Lo, 2019). In particular, sudden losses are likely to upset investors which, in turn, would prevent them to make peace with their losses, thus promoting risk-seeking behaviors (Lerner and Keltner,

\footnotetext{
${ }^{20}$ This sluggish adjustment of the reference level of wealth bears some resemblance with the model of Barberis et al., (2001). However, in our model the adjustment process applies to the reference wealth level directly and not to the loss-aversion parameter.
} 
(a) PT (No recency bias, $\rho^{i}=1$ )

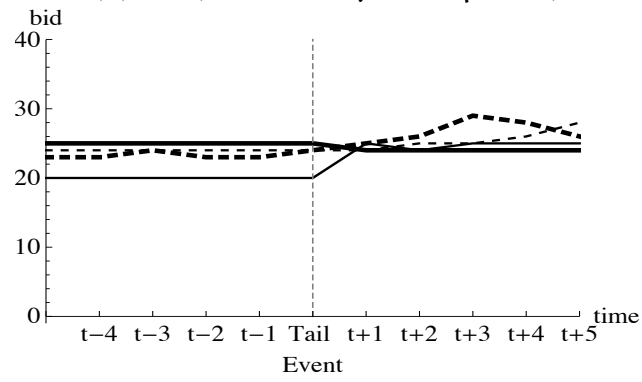

(b) PT (Recency bias, $\rho^{i}=0.5$ )

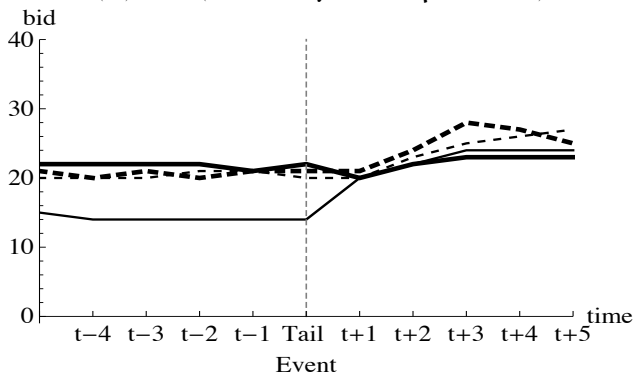

Figure 2: Dynamics of bids around the tail event when it was suffered for PT investors $\left(\lambda^{i}=1.5\right.$ and $\alpha^{i}=$ 0.75) for four values of $\omega^{i}: 0$ (thick solid), 0.25 (thick dashed), 0.5 (thin dashed) and 1 (thin solid). (a) with no recency bias $\left(\rho^{i}=1\right)$. (b) with recency bias $\left(\rho^{i}=0.5\right)$.

2001; Fessler et al., 2004; Lerner et al., 2015). ${ }^{21}$ We thus posit that an emotional reaction to tail losses, and particularly anger, will make it difficult for investors to make peace with their losses.

Risk seeking in the loss domain, which is one of the key features of PT, might thus be due to the fact that losses trigger anger. It follows that the empirical success of PT (Barberis, 2013b) might hinge upon its ability to indirectly capture emotional reactions to risky prospects (Loewenstein et al., 2001). This urges us to test the moderating effect of emotions on the relation between tail losses and risk taking. This leads us to Hypothesis 3.

Hypothesis 3. Anger and Tail Losses Under PT, investors who display anger after suffering tail losses will be more likely to increase their bids compared to those who do not display anger.

We have thus far considered the moderating effect of emotional arousal on investors' utility leaving aside its effect on beliefs. However, beliefs are likely to be influenced by emotions as well (Lopes, 1987; Charness and Levin, 2005; Shefrin, 2010). In Lopes (1987), beliefs are distorted by the emotions of fear and hope, where fear increases the weight associated to the least favorable events and hope increases the weight associated to the most favorable events (see also, e.g., Rottenstreich and Hsee, 2001). This view is consistent with other major theories on the role of emotions in decision making such as appraisal theory (see Lerner and Keltner, 2001; Lerner et al., 2015) and mood-congruence theory according to which people would more easily recall events which are consistent with their current mood (Blaney, 1986; Matt et al., 1992; Watkins et al., 1992; Mayer et al., 1995; Watkins et al., 1996; Koszegi et al., 2019).

\footnotetext{
${ }^{21}$ Taleb (2007) provides a vivid description of traders' anger reactions to tail losses. An alternative possibility is that tail losses generate sadness. Even in that case, previous research suggests risk taking will increase (Lerner and Keltner, 2001; Loewenstein et al., 2001).
} 
Empirical and experimental evidence have shown that fear tends to trigger risk-averse (see Lerner and Keltner, 2001; Cohn et al., 2015; Lerner et al., 2015; Guiso et al., 2018; Noussair and Breaban, 2018; van Well et al., 2019) and cautious (Raghunathan and Pham, 1999) behaviors, while positive feelings tend to lead to more optimistic beliefs (Isen and Patrick, 1983; Johnson and Tversky, 1983) and increased risk taking (Noussair and Breaban, 2018). ${ }^{22}$ Using experimental markets, Andrade et al., (2016) showed that inducing fear using video clips had a negative effect on asset prices compared to inducing excitement. Using analogous techniques, Erb et al., (2002) show that priming people to induce emotional states related to anxiety leads to lesser risk taking. Relatedly, anxiety leads people to focus their attention on threatrelated stimuli (Eysenck and Van Berkum, 1992; Derakshan and Eysenck, 1997) and become more risk averse (Kuhnen and Knutson, 2005; 2011; Knutson et al., 2008). In a recent experimental study, van Well et al., (2019) also show that decreasing anxiety by relieving people from a possible aversive electric shock tends to increase risk taking.

We thus extend our main model to account for the moderating effect of fear and hope associated to tail events on investors' beliefs. In order to separate the effect of tail events on beliefs from their effect on preferences, we will consider only investors who have observed but not suffered the tail event. ${ }^{23}$ The emotional weight assigned to the tail event is captured by the variable $s_{5, j}$ in the beliefs equation (2), which takes value $\mu>0$ when the tail event is observed in period $j$ and value zero otherwise. The case $\mu>1$ $(0<\mu<1)$ captures fear (hope) because it gives an excessive (insufficient) weight to the tail event compared to the emotionless investor $(\mu=1)$ when updating beliefs. In our setup, hopeful investors are those who feel relief when observing the tail event without incurring tail losses.

In Online Appendix II, Figure II.1 shows that both EUT (panel (a)) and PT (panel (b)) investors who are fearful ( $\mu=2$, thick dashed lines and $\mu=4$, thick solid lines) are more likely to decrease their bids than investors who do not experience fear $(\mu \leq 1)$ as a result of observing the tail event. By contrast, investors who are hopeful $(\mu=0.25$, thin solid lines and $\mu=0.5$, thin dashed lines) are less likely to decrease their bids than investors who do not experience hope $(\mu \geq 1){ }^{24}$

Emotional arousal is also likely to have an impact on beliefs when tail losses are suffered leading to

\footnotetext{
${ }^{22}$ Finance scholars have also assessed the effect of mood on stock markets. For example, Hirshleifer and Shumway (2003) show that positive mood, as proxied by sunny weather, correlated to higher returns in a large set of international stock markets. In the same vein, Goetzmann et al., (2015) show, using survey data, that institutional investors report lesser perception of overpricing of stocks in sunnier days in New York.

${ }^{23}$ Although this separation is clear in our model because fear and hope only affect beliefs, Kuhnen and Knutson (2011) have shown that emotions, such as anxiety, can also decrease one's preference for risk.

${ }^{24}$ The effect of hope and fear on bids after tail events are observed, yet not suffered, is more pronounced when investors suffer from a recency bias (i.e., $\rho^{i}=0.5$ ), as is shown in Online Appendix III (panel (a) in Figures III.4.1 and III.4.2).
} 
increased pessimism (Kuhnen, 2015). This effect could potentially counterbalance the increase in bids that is captured in Hypothesis 2. In particular, if emotional arousal after tail losses triggers fear rather than anger, we would expect tail losses to prompt a decrease rather than an increase in bids (Lerner et al., 2015). In Online Appendix II, Figure II.2 (panel (b)), we show that PT investors who experience fear $(\mu=2$, thick dashed lines and $\mu=4$, thick solid lines) after suffering tail losses are less likely to increase their bids than those who did not experience fear $(\mu \leq 1$, thin lines).

We summarize our predictions regarding fear and hope in Hypothesis 4.

\section{Hypothesis 4. Fear, Hope, Beliefs and Tail Events}

i) Under EUT \& PT, investors who display fear will be more likely to decrease their bids after observing, yet not suffering, a tail event compared to those who display hope.

ii) Under EUT \& PT, investors who display fear after suffering tail losses will be less likely to increase their bids compared to those who display hope.

\subsubsection{Emotional arousal, survival and earnings}

Our study of the moderating role of emotions on decision-making has focused on investors' responses to tail events yet ignoring anticipatory emotions triggered by the eventuality of incurring tail losses. Here, we tackle the broad question of whether anticipatory emotional arousal affects investment decisions and whether it promotes or hinders financial gains (Damasio, 1994; Bechara et al., 1997; Lo and Repin, 2002; Lo et al., 2005; Shiv et al., 2005). Bechara et al., (1997) show that patients with amygdala lesions who do not produce anticipatory emotional arousal to potential losses fail to avoid bankruptcy in the Iowa Gambling Task. Bechara et al., (1997) and Bechara and Damasio (2005) interpret these results in the light of the 'somatic marker hypothesis' according to which emotions play a key role in successful decision making because they allow people to learn which decisions are advantageous and which ones are not. This argument is in line with the widespread view that emotions are adaptive, having emerged as a critical tool to increase our chances of survival (e.g., Damasio, 1994; Ekman, 1999; Cosmides and Tooby, 2000; Cacioppo et al., 2000; Ledoux, 1996, 2012; Lerner et al., 2015).

In our setup which is characterized by an asset with unlikely large losses, anticipatory arousal is likely to signal acute physiological awareness of potential large losses. We would expect investors who exhibit high levels of anticipatory arousal to be particularly cautious, thus placing lower bids to reduce the odds of going bankrupt as a result of the tail event. However, the fact that investors with high anticipatory arousal 
are more likely to avoid bankruptcy than those with low anticipatory arousal does not necessarily imply that they will achieve higher earnings. Avoiding bankruptcy will lead to profit maximization only when tail events are relatively frequent, which is the case in some of our experimental sessions and in the design of Bechara et al., (1997). When tail events are particularly rare or when bankruptcy is not an eventuality then less emotional traders who ignore tail losses might actually earn more money by taking on more risks. This reasoning helps us understand the apparently contradictory results regarding the role of emotions on traders' performance in a variety of experiments (Bechara et al., 1997; Lo et al., 2005; Shiv et al., 2005).

In our model, we capture anticipatory arousal using the loss aversion parameter $\left(\lambda^{i}\right)$. In our setup, the asset delivers a small positive reward in more than $99 \%$ of the cases so that losses are uniquely identified with the realization of the tail event. Therefore, in contrast with a standard situation featuring frequent gains and losses, our setup is one in which the loss aversion parameter $\left(\lambda^{i}\right)$ can directly capture the anticipated disutility associated to incurring tail losses. A higher $\lambda^{i}$ reflects the fact that an investor anticipates tail losses to be more painful. To assess the overall effect of anticipatory arousal, we report the results of simulations which are conducted for a broad combination of parameter values of the model. ${ }^{25}$ Figure 3 shows the results of these simulations for the average bid (panel (a)), the proportion of tail events suffered by investors (panel (b)), the frequency of bankruptcy (panel (c)), and final wealth (panel (d)) across four possible values of $\lambda^{i} \in\{1.0,1.5,2.0,2.5\}$ depending on the number of tail events. Figure 3 shows that investors with higher levels of $\lambda^{i}$ will bid lower on average, and will thus be less likely to be affected by the tail event and go bankrupt.

The relationship between $\lambda^{i}$ and final wealth is more complex (see panel (d)). Final wealth decreases with $\lambda^{i}$ when tail events are infrequent (i.e., 0,1 or 2) but it is not necessarily the case when they are more frequent (e.g., 3 or 4). This mixed result appears because of two opposite effects of posting lower bids. An investor who bids low values will purchase the asset less frequently, which, in the absence of tail events, will be detrimental to the investors' wealth because assets which have a positive expected value fail to be acquired. However, lower bids also insulate investors against tail events thus lowering the risk of bankruptcy. The relationship between $\lambda^{i}$ and final wealth thus critically depends on the number of tail events. In Online Appendix II, Figure II. 3 reports a slightly positive relationship between $\lambda^{i}$ and final wealth when tail events occurred 3 times or more (thick solid line). In case the tail event happened twice or less (thin solid line), final wealth declines with $\lambda^{i}$. We summarize these results in Hypothesis 5.

\section{Hypothesis 5. Anticipatory Arousal, Bankruptcy and Earnings}

\footnotetext{
${ }^{25}$ See Online Appendix II for details of the simulations.
} 
(a) Average bid (cents)

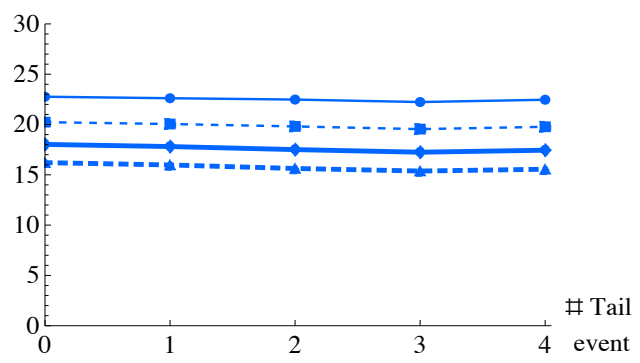

(c) Frequency of bankruptcy

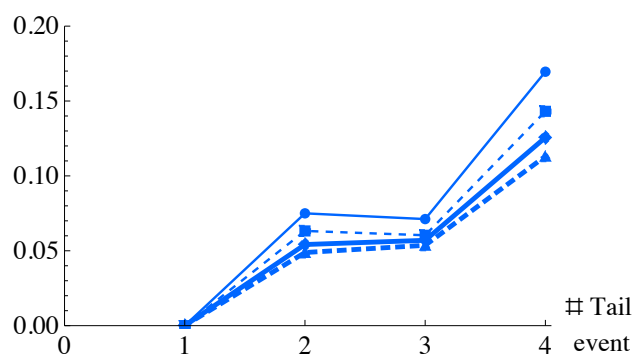

(b) Proportion of tail events suffered

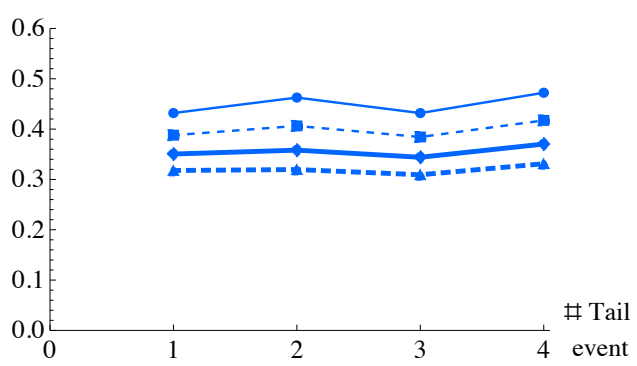

(d) Final wealth (cents)

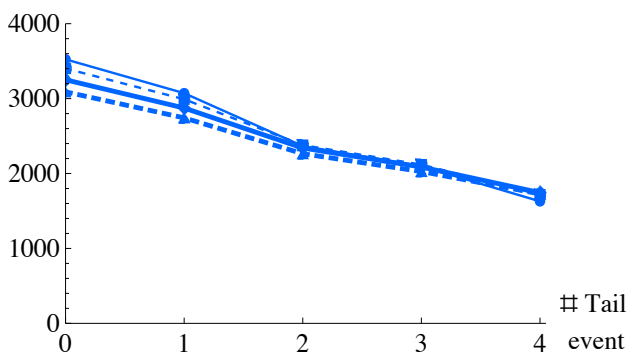

Figure 3: (a) Average bid, (b) Proportion of tail events that are suffered, (c) Frequency of bankruptcy, and (d) Final wealth, for four values of $\lambda^{i}: 1.0$ (thin solid), 1.5 (thin dashed), 2.0 (thick solid), 2.5 (thick dashed). The horizontal axis represents the number of tail events in the simulated series. The values in each graph are averages over simulations varying all the other parameters of the model.

i) Investors who display high levels of anticipatory arousal will bid lower and will be less likely to suffer tail events and go bankrupt than those who do not.

ii) Investors who display high levels of anticipatory arousal will earn more (less) than those who do not in sessions in which tail events occur frequently (rarely).

\section{Results}

\subsection{Hypotheses $1 \& 2$ (Tail Events, Tail Losses and Bids)}

We start by testing Hypotheses 1and 2, thus considering the response of investors to tail events in cases in which they incurred tail losses and in cases in which they did not. For the sake of our analyses, we study the direction of changes in bids rather than their absolute value because investors kept their bids constant from period to period in almost half the cases $(49.1 \%) .{ }^{26}$

In the left panel of Figure 4 , we show that $30.0 \%$ of the investors lowered their bids after a tail event was

\footnotetext{
${ }^{26}$ Note that the proportion of stable bids is unaffected by the occurrence of tail events or tail losses (see Appendix A, Table A.1).
} 


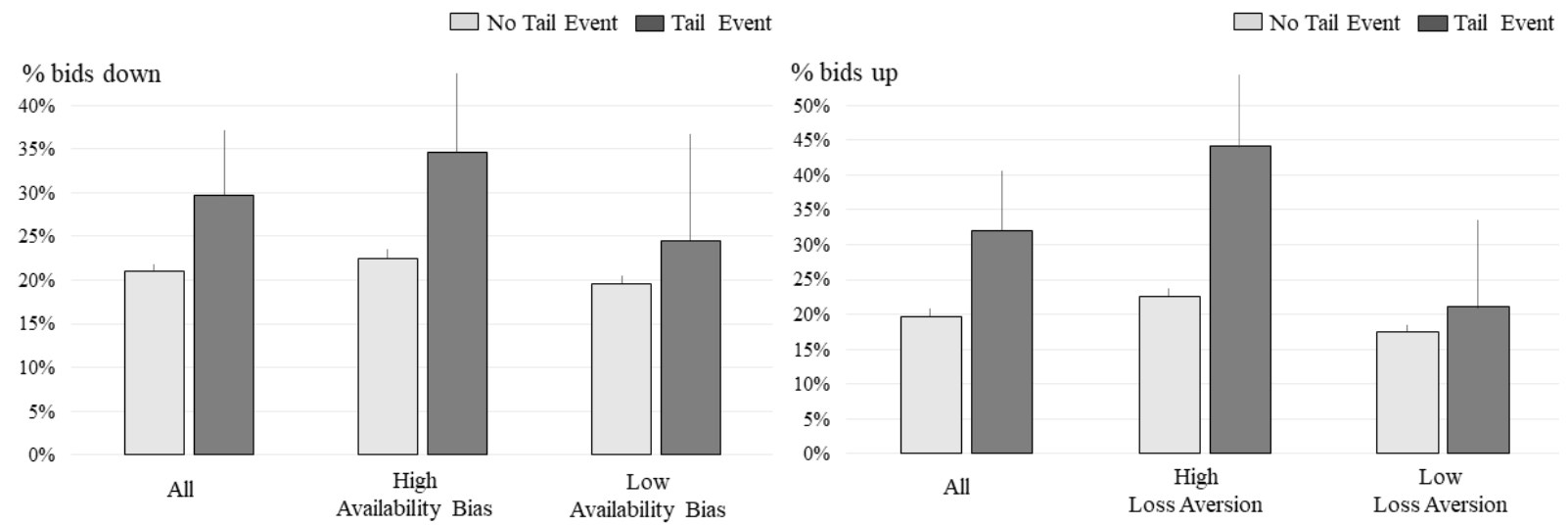

Figure 4: (Left) Percentage of times investors decreased their bids in the period after observing, yet not experiencing, a tail or a non-tail event, for all participants and for those with high (above-median) and low (below-median) levels of the availability index. (Right) Percentage of times investors increased their bids in the period after experiencing, a tail or a non-tail event, for all participants and for those with high (abovemedian) and low (below-median) levels of the loss aversion index. Upper bounds of the $95 \%$ confidence intervals are displayed.

observed, yet not suffered, compared to $21.0 \%$ after observing a non-tail event. This difference appears to be more pronounced for investors who exhibit a high rather than a low availability bias. These observations are in line with Hypothesis 1. The availability bias is measured using two of the tests in our Day 1 session, which were adapted from Tversky and Kahneman (1974) (see Online Appendix I.1, Blocks 7 and 10). We define an availability index as the sum of the standardized scores on the two measures and categorize highavailability (low-availability) bias investors as those who score above (below) the median of the availability index. $^{27}$

In the right panel of Figure 4, we show that $31.9 \%$ of the investors increased their bids in the period after incurring tail losses, compared to $19.6 \%$ after experiencing a non-tail event. This difference is more pronounced for investors who exhibit a high (above-median) rather than low (below-median) loss aversion index. The loss aversion index is measured as the number of times a participant chose the option involving lesser losses in the loss aversion test administered in Day 1 (see Brink and Rankin, 2013, in Online Appendix I.1, Block 8). These observations are in line with Hypothesis 2.

In Tables 1 and 2, we assess the significance of these findings by conducting panel probit regressions with random effects and session fixed effects using robust standard errors at the individual level (Huber,

\footnotetext{
${ }^{27}$ The first availability score is the number of wrong answers (out of five) on the first availability heuristic test (see Online Appendix I.1, Block 7) whereas the second availability score is computed as the ratio of correct answers involving a famous name with respect to the total number of correct answers (see Online Appendix I.1, Block 10).
} 
1967; White, 1980). In Table 1, the dependent variable, which is referred to as 'DOWN DUMMY', takes value one if investors decreased their bid in the current period compared to the previous period. We control for the period in which a bid was placed ('Period') and for the number of tail events an investor had observed before a bid was placed ('Number of Tail Events'). To test Hypothesis 1, we consider the case in which investors had not purchased the asset in the previous period so that no payoffs were received regardless of the type of event that was observed. In regressions (1) to (3), our explanatory variable of interest is 'Tail Event Dummy' which takes value one if a tail event was observed in the previous period. This variable thus captures the extent to which a decrease in bids is more likely after a tail event has been observed compared to a non-tail event, thus providing a direct test for Hypothesis 1 . We observe that the 'Tail Event Dummy' is positive and significant in regression (1) thus confirming the first part of Hypothesis 1 according to which investors are more likely to decrease their bids after observing, yet not suffering, a tail event compared to a non-tail event. The marginal effect associated with the 'Tail Event Dummy' is $8.0 \%$ $(\mathrm{p}$-value $=0.029)$ so that, after observing yet not suffering a tail event, investors were $8 \%$ more likely to decrease their bids compared to observing a non-tail event. In regressions (2) and (3), we show that the effect of tail events on the likelihood of decreasing bids is marginally significant for investors with a high availability bias $(\mathrm{p}$-value $=0.071)$ whereas it is not significant for those with a low availability bias. The interaction effect 'Tail Event Dummy $\times$ High Availability Dummy' fails to reach significance in regression (4), where the 'High Availability Dummy' takes value one when an investor's availability index is above the median of all investors' scores. Thus, the difference between high- and low- availability bias investors on the impact of tail events does not reach statistical significance. ${ }^{28}$

To test Hypothesis 2, we assess whether investors increased their bids after experiencing a tail rather than a non-tail event (see Table 2). That is, we compare investors' likelihood of increasing their bids after purchasing the asset when a tail event rather than a non-tail event occurred in the previous period. The dependent variable, which is referred to as 'UP DUMMY', takes value one if investors increased their bid in the current period compared to the previous period. In Table 2, we observe that the 'Tail Event Dummy' is positive and significant in regression (1) thus confirming Hypothesis 2 that investors are more likely to increase their bids after experiencing tail losses than after experiencing a non-tail event. The marginal

\footnotetext{
${ }^{28}$ Nonetheless, robustness checks show that this difference turns significant for alternative specifications of the availability bias (see Online Appendix IV.1) such as using the availability index instead of the 'High Availability Dummy' to define the interaction term in regression (4) ('Tail Event Dummy $\times$ Availability Index'). The interaction term is also significant when using the score on the second availability test whereas it fails to reach statistical significance when using the scores on the first availably test (see Table IV.1.1). In addition, we obtain similar results to those reported in Table 1 when using recency bias scores instead of using the availability test scores. The recency bias score was computed as the number of names which were not recalled correctly in the second availability test (see Online Appendix I.1, Block 10) (see Table IV.1.2).
} 
Table 1: Decrease in Bids, Availability Bias and Tail Events. Panel probit regressions with random effects and robust standard errors clustered at the individual levels in parentheses, session fixed effects included.

\begin{tabular}{|c|c|c|c|c|}
\hline VARIABLE & & DOWI & JUMMY & \\
\hline $\begin{array}{l}\text { SAMPLE } \\
\text { (Investors did not buy asset in } \\
\text { previous period) }\end{array}$ & (1) & $\begin{array}{l}(2) \\
\text { High } \\
\text { Availability } \\
\text { Bias }\end{array}$ & $\begin{array}{l}\text { (3) } \\
\text { Low } \\
\text { Availability } \\
\text { Bias }\end{array}$ & (4) \\
\hline Tail Event Dummy & 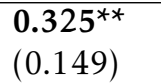 & $\begin{array}{l}\mathbf{0 . 4 1 6}^{*} \\
(0.233)\end{array}$ & $\begin{array}{l}\mathbf{0 . 2 1 2} \\
(0.187)\end{array}$ & $\begin{array}{l}0.213 \\
(0.185)\end{array}$ \\
\hline $\begin{array}{l}\text { Tail Event Dummy } \times \text { High } \\
\text { Availability Dummy }\end{array}$ & - & - & - & $\begin{array}{l}0.212 \\
(0.297)\end{array}$ \\
\hline High Availability Dummy & - & - & - & $\begin{array}{l}0.107 \\
(0.137)\end{array}$ \\
\hline Period & $\begin{array}{l}-0.001^{\star *} \\
(0.000)\end{array}$ & $\begin{array}{l}-0.000 \\
(0.001)\end{array}$ & $\begin{array}{l}-0.001^{* *} \\
(0.000)\end{array}$ & $\begin{array}{l}-0.001^{* *} \\
(0.000)\end{array}$ \\
\hline Number of Tail Events & $\begin{array}{l}0.017 \\
(0.034)\end{array}$ & $\begin{array}{l}0.006 \\
(0.048)\end{array}$ & $\begin{array}{l}0.033 \\
(0.049)\end{array}$ & $\begin{array}{l}0.017 \\
(0.034)\end{array}$ \\
\hline Constant & $\begin{array}{l}-0.823^{* * *} \\
(0.306)\end{array}$ & $\begin{array}{l}-1.006^{* *} \\
(0.511)\end{array}$ & $\begin{array}{l}-0.584^{* * *} \\
(0.052)\end{array}$ & $\begin{array}{l}-0.885^{* * *} \\
(0.306)\end{array}$ \\
\hline Observations & 13,793 & 6,806 & 6,987 & 13,793 \\
\hline Number of Investors & 86 & 42 & 44 & 86 \\
\hline
\end{tabular}

${ }^{* * *} \mathrm{p}<0.01,{ }^{* *} \mathrm{p}<0.05,{ }^{*} \mathrm{p}<0.1$

effect of the 'Tail Event Dummy' is 9.3\% ( $\mathrm{p}$-value $=0.037)$ so that after suffering tail losses, investors are $9.3 \%$ more likely to increase their bids compared to the case in which they experienced a non-tail event. In regressions (2) and (3), we show that the effect of tail events on the likelihood of increasing bids is only significant for the case of investors with high loss aversion. This is consistent with the fact that Hypothesis 2 was derived in the case of PT investors and not in the case of EUT investors. However, the positive interaction effect 'Tail Event $\times$ High Loss Aversion Dummy' fails to reach statistical significance in regression (4), where the 'High Loss Aversion Dummy' takes value one when an investor's loss aversion index is above the median of all investors' scores.

In sum, we find strong evidence for the first part of Hypothesis 1 according to which investors who observe tail events without suffering tail losses tend to decrease their bids. We report suggestive evidence for the second part of Hypothesis 1 regarding the mediating role of availability and recency biases. We also find support for Hypothesis 2 according to which investors who suffer tail losses are more likely to increase their bids compared to investors who purchased the asset but did not suffer tail losses. These results are robust to adding individual controls in the regression analyses, controlling for potential autocorrelation and selection issues (see Online Appendix IV.1 for Hypothesis 1 and Online Appendix IV.2 for Hypothesis 
Table 2: Increase in Bids, Loss Aversion and Tail Events. Panel probit regressions with random effects and robust standard errors clustered at the individual levels in parentheses, session fixed effects included.

\begin{tabular}{|c|c|c|c|c|}
\hline VARIABLE & & UP D & MMY & \\
\hline & (1) & (2) & (3) & (4) \\
\hline SAMPLE & & High Loss & Low Loss & \\
\hline $\begin{array}{l}\text { (Investors bought asset in previ- } \\
\text { ous period) }\end{array}$ & & Aversion & Aversion & \\
\hline Tail Event Dummy & $\begin{array}{l}0.392^{* *} \\
(0.186)\end{array}$ & $\begin{array}{l}0.593^{* *} \\
(0.269)\end{array}$ & $\begin{array}{l}0.177 \\
(0.259)\end{array}$ & $\begin{array}{l}0.205 \\
(0.260)\end{array}$ \\
\hline Tail Event $\times$ High Loss Aversion & - & - & - & 0.324 \\
\hline Dummy & & & & $(0.364)$ \\
\hline High Loss Aversion Dummy & - & - & - & $\begin{array}{l}0.272^{*} \\
(0.141)\end{array}$ \\
\hline Period & $\begin{array}{l}-0.001^{* * *} \\
(0.000)\end{array}$ & $\begin{array}{l}-0.001 \\
(0.001)\end{array}$ & $\begin{array}{l}-0.002^{\star * *} \\
(0.001)\end{array}$ & $\begin{array}{l}-0.001^{* * *} \\
(0.000)\end{array}$ \\
\hline Number of Tail Events & $\begin{array}{l}0.046 \\
(0.043)\end{array}$ & $\begin{array}{l}0.022 \\
(0.069)\end{array}$ & $\begin{array}{l}0.062 \\
(0.057)\end{array}$ & $\begin{array}{l}0.046 \\
(0.043)\end{array}$ \\
\hline Constant & $\begin{array}{l}-0.885^{* * *} \\
(0.266)\end{array}$ & $\begin{array}{l}-0.820^{* * *} \\
(0.067)\end{array}$ & $\begin{array}{l}-1.008 \\
(0.670)\end{array}$ & $\begin{array}{l}-1.050^{* * *} \\
(0.301)\end{array}$ \\
\hline Observations & 10,189 & 4,231 & 5,958 & 10,189 \\
\hline Number of Investors & 86 & 37 & 49 & 86 \\
\hline
\end{tabular}

${ }^{* * *} \mathrm{p}<0.01,{ }^{* *} \mathrm{p}<0.05,{ }^{*} \mathrm{p}<0.1$

2) as well as to using non-parametric tests instead of regression analyses (See Online Appendix V).

We have thus far ignored the possible moderating role of emotions in explaining investors' reactions to tail events. We study these effects by testing Hypotheses 3 and 4.

\subsection{Hypothesis 3 (Emotional Arousal, Anger and Tail losses)}

According to Hypothesis 3, the increase in bids following tail losses will be more pronounced for investors who exhibit an emotional reaction to tail events, especially if this response is driven by anger motives. To assess whether investors were emotionally aroused by an event, we evaluated their electrodermal activity using standard physiological techniques (see Section 2.2). Recall that we refer to feedback arousal as the physiological reaction, as measured with electrodermal activity, right after an investor observed whether a tail event occurred and whether tail losses were incurred. ${ }^{29}$ We define a 'Feedback Arousal Dummy' as taking value one in a given period if an investor exhibited significant feedback arousal. Overall, this variable takes value one in $25.0 \%$ of the cases and in $53.0 \%$ of the cases when tail losses are incurred.

To test Hypothesis 3 directly, we need to identify whether feedback arousal is associated with anger.

\footnotetext{
${ }^{29}$ Among the 86 participants, we could not obtain reliable physiological recordings for two of them because of deficient electrodes.
} 
To that end, we used the HEXACO personality test (Ashton and Lee, 2009) completed by participants in Day 1 to evaluate whether a person had an anger-prone personality. We categorized as anger-prone those participants who scored above the median in the anger facet of personality (Cronbach-alpha $=0.858$ ) and as not anger-prone those who scored below. We define the 'Anger Dummy' as taking value one for investors who are categorized as anger-prone and value zero otherwise. This procedure helps us evaluate the valence associated to feedback arousal without interfering with the choice experiment. Our approach is thus to assess, as stated in Hypothesis 3, whether PT investors who are categorized as anger-prone are especially likely to increase their bids as a result of the feedback arousal generated by tail losses.

In Table 3, we replicate our regression analysis of Table 2 to study whether PT investors increased their bids out of emotional arousal and anger. We thus consider the case of investors who are loss averse so that the 'High Loss Aversion Dummy' equals one. In line with Table 2, we also consider the case of investors who purchased the asset in the previous period, thus incurring tail losses when a tail event occurred. In regressions (1) and (2) of Table 3, we start by showing that PT investors are more likely to increase their bids after suffering tail losses than after experiencing a non-tail event when they exhibited feedback arousal (regression (2)) whereas this was not the case for PT investors who did not exhibit feedback arousal (regression (1)). In regression (3), the coefficient for 'Tail Event $\times$ Feedback Arousal Dummy' is positive and significant, thus showing that the increase in bids due to incurring tail losses is indeed significantly more pronounced for investors who displayed feedback arousal in the previous period. These findings are consistent with Hypothesis 3 as long as we assume that feedback arousal triggered by tail losses is associated with anger. To test Hypothesis 3 more precisely, regressions (4) and (5) assess the effect of feedback arousal as a result of tail losses, which is captured by the variable 'Tail Event $\times$ Feedback Arousal Dummy', for investors who have an anger-prone personality (regression (4)) and for those who do not (regression (5)). In line with Hypothesis 3, we observe that the coefficient for 'Tail Event $\times$ Feedback Arousal Dummy' is significantly positive only for the case of anger-prone investors. This suggests that the increase in bids due to feedback arousal when incurring tail losses is significantly more pronounced for investors who are prone to anger than for those who are not. In regression (6), the positive significance of the triple interaction term 'Tail Event $\times$ Feedback Arousal $\times$ Anger Dummy' confirms this finding.

In sum, we find strong evidence for Hypothesis 3 according to which angry investors who are emotionally aroused by tail losses are more likely to increase their bids than investors who do not exhibit anger. We show our findings to be robust to alternative specifications (see Online Appendix IV.3). In addition, we tested our main effects using non-parametric tests (see Online Appendix V). 
Table 3: Increase in Bids, Tail Losses, Emotional Arousal and Anger. Panel probit regressions with random effects and robust standard errors clustered at the individual levels in parentheses, session fixed effects included.

\begin{tabular}{|c|c|c|c|c|c|c|}
\hline \multicolumn{3}{|l|}{ VARIABLE } & \multicolumn{4}{|c|}{ UP DUMMY } \\
\hline $\begin{array}{l}\text { SAMPLE } \\
\text { (PT investors who bought } \\
\text { asset in previous period) }\end{array}$ & $\begin{array}{l}\text { (1) } \\
\text { No } \\
\text { feedback } \\
\text { arousal }\end{array}$ & $\begin{array}{l}\text { (2) } \\
\text { Feedback } \\
\text { arousal }\end{array}$ & $(3)$ & $\begin{array}{l}(4) \\
\text { Anger- } \\
\text { prone }\end{array}$ & $\begin{array}{l}(5) \\
\text { Not } \\
\text { anger- } \\
\text { prone }\end{array}$ & (6) \\
\hline Tail Event Dummy & $\begin{array}{l}-0.154 \\
(0.323)\end{array}$ & $\begin{array}{l}1.039^{* * *} \\
(0.368)\end{array}$ & $\begin{array}{l}-0.185 \\
(0.328)\end{array}$ & $\begin{array}{l}-5.351^{* * *} \\
(0.222)\end{array}$ & $\begin{array}{l}0.003 \\
(0.355)\end{array}$ & $\begin{array}{l}0.014 \\
(0.350)\end{array}$ \\
\hline $\begin{array}{l}\text { Feedback } \\
\text { Dummy }\end{array}$ & - & - & $\begin{array}{l}-0.075 \\
(0.057)\end{array}$ & $\begin{array}{l}0.051 \\
(0.080)\end{array}$ & $\begin{array}{l}-0.157^{\star *} \\
(0.074)\end{array}$ & $\begin{array}{l}-0.155^{\star *} \\
(0.074)\end{array}$ \\
\hline $\begin{array}{l}\text { Tail Event } \times \text { Feedback } \\
\text { Arousal Dummy }\end{array}$ & - & - & $\begin{array}{l}1.409^{* *} \\
(0.563)\end{array}$ & $\begin{array}{l}7.519^{* * *} \\
0.397\end{array}$ & $\begin{array}{l}0.943 \\
(0.696)\end{array}$ & $\begin{array}{l}0.936 \\
(0.690)\end{array}$ \\
\hline $\begin{array}{l}\text { Tail Event } \times \text { Feedback } \\
\text { Arousal } \times \text { Anger Dummy }\end{array}$ & - & - & - & - & - & $\begin{array}{l}6.469^{* * *} \\
(0.825)\end{array}$ \\
\hline $\begin{array}{l}\text { Tail Event } \times \text { Anger } \\
\text { Dummy }\end{array}$ & - & - & - & - & - & $\begin{array}{l}-5.300^{* * *} \\
(0.393)\end{array}$ \\
\hline $\begin{array}{l}\text { Feedback Arousal } \times \text { Anger } \\
\text { Dummy }\end{array}$ & - & - & - & - & - & $\begin{array}{l}0.201^{*} \\
(0.112)\end{array}$ \\
\hline Anger Dummy & - & - & - & - & - & $\begin{array}{l}0.126 \\
(0.215)\end{array}$ \\
\hline Period & $\begin{array}{l}-0.001 \\
(0.001)\end{array}$ & $\begin{array}{l}-0.002^{*} \\
(0.001)\end{array}$ & $\begin{array}{l}-0.001 \\
(0.001)\end{array}$ & $\begin{array}{l}-0.001 \\
(0.001)\end{array}$ & $\begin{array}{l}-0.001 \\
(0.001)\end{array}$ & $\begin{array}{l}-0.001 \\
(0.001)\end{array}$ \\
\hline $\begin{array}{l}\text { Number of } \\
\text { Tail Events }\end{array}$ & $\begin{array}{l}-0.063 \\
(0.073)\end{array}$ & $\begin{array}{l}0.166^{\star *} \\
(0.078)\end{array}$ & $\begin{array}{l}0.004 \\
(0.06)\end{array}$ & $\begin{array}{l}-0.007 \\
(0.065)\end{array}$ & $\begin{array}{l}0.016 \\
(0.093)\end{array}$ & $\begin{array}{l}0.000 \\
(0.061)\end{array}$ \\
\hline Constant & $\begin{array}{l}-0.776^{* * *} \\
(0.0853)\end{array}$ & $\begin{array}{l}-0.909^{* * *} \\
(0.230)\end{array}$ & $\begin{array}{l}-0.795^{\star * *} \\
(0.064)\end{array}$ & $\begin{array}{l}-0.825^{\star * *} \\
(0.101)\end{array}$ & $\begin{array}{l}-0.774^{\star * *} \\
(0.082)\end{array}$ & $\begin{array}{l}-0.835^{\star * *} \\
(0.106)\end{array}$ \\
\hline Observations & 3,832 & 1,277 & 5,109 & 1,961 & 2,981 & 5,109 \\
\hline $\begin{array}{l}\text { Number of } \\
\text { Investors }\end{array}$ & 44 & 44 & 44 & 16 & 27 & 44 \\
\hline
\end{tabular}

${ }^{* * *} \mathrm{p}<0.01,{ }^{* *} \mathrm{p}<0.05,{ }^{*} \mathrm{p}<0.1$

\subsection{Hypothesis 4 (Fear, Hope and Tail Events)}

Hypothesis 4 states that emotional arousal triggered by tail events will impact investors' decisions even in cases in which tail losses are avoided. This is the case because beliefs will be impacted by tail events. The logic underlying Hypothesis 4 is in line with the fact that investors showed an emotional reaction to tail events whether they entailed tail losses or not (see Figure A.3 in Appendix A).

To test Hypothesis 4, we assess fearful and hopeful personality traits using the HEXACO personality test of Day $1 .^{30}$ A person can score above the median participants' scores in both fear and hope personality

\footnotetext{
${ }^{30}$ Cronbach-alpha $=0.591$ and 0.680 , respectively. These values are modest, especially for fear, but this might not be surprising given that each facet only consists of either three (fear) or two items (hope). Nonetheless, we obtain similar results using the personality trait of emotionality in HEXACO instead of the fear facet (see Online Appendix IV.4, Tables IV.4.4 and IV.4.8). Emotionality is
} 
facets, thus being categorized as both fearful and hopeful. This is the case for 22 out of our 86 participants. We thus only consider fearful people who are not hopeful ('Fearful Dummy' equals value one) and hopeful people who are not fearful ('Hopeful Dummy' equals one) so as to avoid confounds in testing Hypothesis 4 . We follow the same approach as for testing Hypothesis 3 by focusing on the sign and significance of the variable 'Tail Event $\times$ Feedback Arousal Dummy', which captures the effect of being emotionally aroused by observing a tail event. Because Hypothesis 4 i refers to a situation in which tail losses are not incurred, we consider in Table A.2 (see Appendix A), as in Table 1, the case in which investors did not buy the asset in the previous period. In line with Hypothesis $4 \mathrm{i}$, we observe that the coefficient for 'Tail Event $\times$ Feedback Arousal Dummy' is negative and marginally significant for the case of hopeful (not fearful) investors (regression (1)) whereas it is positive yet not significant for the case of fearful (not hopeful) investors. This suggests that the decrease in bids due to feedback arousal when observing tail events is less pronounced for investors who are hopeful than for those who are fearful. In regression (3), the negative yet not significant $(\mathrm{p}$-value $=0.108)$ coefficient for the triple interaction term 'Tail Event $\times$ Feedback Arousal $\times$ Hopeful Dummy' offers suggestive evidence for this claim. In regression (4), we show that this variable is significant when restricting the analysis in regression (3) to those investors who have a high availability bias and are thus more likely to adjust their beliefs when observing a new event. This moderating effect of the availability bias is also in line with our model (see panel (a) in Figures III.4.1 and III.4.2, Online Appendix III).

To test Hypothesis 4ii, we replicate the analysis of Table A.2 (see Table A.3 in Appendix A) for the case in which the asset was purchased in the previous period so that tail losses were incurred in the case of tail events. We also consider the 'UP DUMMY' as dependent variable instead of the 'DOWN DUMMY'. Hypothesis 4ii helps us understand how the effect of fear and hope can impact investors' tendency to raise their bids after incurring tail losses (see Hypothesis 3). In line with Hypothesis 4ii, we observe that the coefficient for 'Tail Event $\times$ Feedback Arousal Dummy' is positive and significant for the case of hopeful (not fearful) investors (regression (1)), whereas it is lower and not significant for the case of fearful (not hopeful) investors. This suggests that the increase in bids due to feedback arousal when incurring tail losses is less pronounced for investors who are fearful than for those who are hopeful. In regressions (3) and (4), the positive and significant coefficient for the triple interaction term 'Tail Event $\times$ Feedback Arousal $\times$ Hopeful Dummy' confirms this finding. Regressions (1) and (2) also show that hopeful investors are overall comprised of the following facets: fear, anxiety, dependence and sentimentality. It includes a total of 10 items with a Cronbach-alpha of 0.796 . 
more likely to increase their bids after incurring tail losses (in line with Hypothesis 2) whereas this is not the case for fearful investors.

In sum, we find suggestive evidence for Hypothesis $4 \mathrm{i}$ according to which hopeful investors who are emotionally aroused by observing, yet not suffering, tail events are less likely to decrease their bids than fearful investors. ${ }^{31}$ In addition, we find strong evidence for Hypothesis 4 ii according to which fearful investors who are emotionally aroused by suffering tail losses are less likely to increase their bids than hopeful investors. Interestingly, the depressing effect of fear on bids does not offset the positive effect of emotional arousal and anger highlighted in Hypothesis 3. In particular, the findings in Table 3 which support Hypothesis 3 continue to hold even if we consider the subset of investors who are fearful, yet not hopeful (see Appendix A, Table A.4). Finally, we show our findings for Hypothesis 4 to be robust to alternative specifications (see Online Appendix IV.4) as well as non-parametric tests (see Online Appendix V).

\subsection{Hypothesis 5 (Anticipatory Arousal, Bankruptcy and Earnings)}

Our final hypothesis regards the effect of anticipatory arousal on bids, bankruptcy and earnings. We assess baseline anticipatory arousal by computing the electrodermal activity of investors during the decisionmaking phase as in Bechara et al., (1997) (see Section 2.2). In particular, we define the baseline value as the average anticipatory arousal in the first five periods of the experiment, thus ensuring that no tail event had yet occurred in any session. ${ }^{32}$ We categorized investors as exhibiting high (low) baseline anticipatory arousal when they scored above (below) the median score of all participants. We define the 'High Anticipatory Arousal Dummy' to be equal to one for those investors who are categorized as exhibiting high baseline anticipatory arousal.

In Figure 5 (left panel), we show, in line with Hypothesis 5i, that investors with high baseline anticipatory arousal posted bids that were on average $17.2 \%$ lower (21.153) than those with low baseline anticipatory arousal (24.790). ${ }^{33}$ The size of this effect is moderate (Cohen's $d=0.471$ ). Because investors with high baseline anticipatory arousal posted lower bids, they were less likely to buy the asset in a given period and were thus less likely to incur tail losses (see middle panel in Figure 5). As a result, high baseline anticipatory arousal protected investors against bankruptcy which typically occurred, in our setup, when

\footnotetext{
${ }^{31}$ Hypothesis $4 \mathrm{i}$ is further supported by our robustness checks because all but one of the six specifications estimating the interaction term 'Tail Event $\times$ Feedback Arousal $\times$ Hopeful Dummy' report a statistically significant coefficient (see Tables IV.4.1 to IV.4.3). The only exception corresponds to regression (3) in Table IV.4.1 where the p-value for the interaction term is equal to 0.106.

${ }^{32}$ The earliest tail event appeared in period 7 in session 13.

${ }^{33}$ Because our measurement of emotional arousal used the first five periods, we only took into account those bids after period 5. Similar results are obtained otherwise.
} 

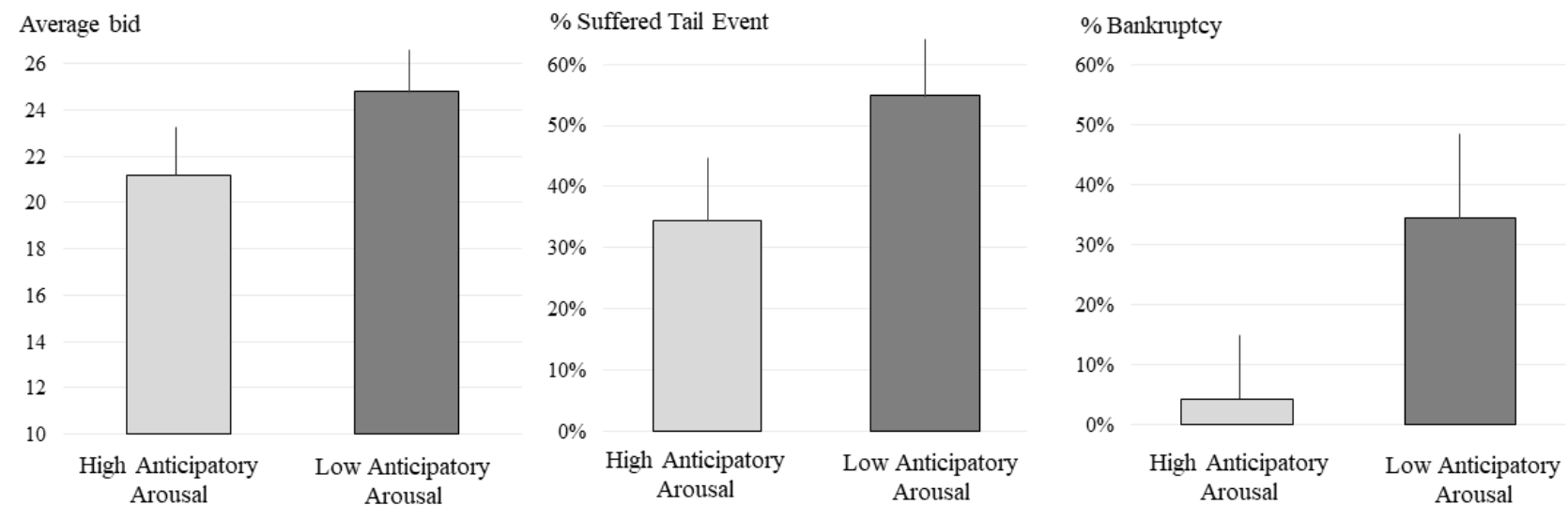

Figure 5: (Left) Average bids of investors with high and low baseline anticipatory arousal (categorized using a median split). (Middle) Average percentage of investors who incurred tail losses across levels of anticipatory arousal. (Right) Average percentage of investors who went bankrupt across levels of anticipatory arousal. Upper bounds of the $95 \%$ confidence intervals are displayed.

an investor suffered tail losses in two occasions. Investors who displayed high baseline anticipatory arousal went bankrupt in only $4.3 \%$ of the cases compared to $34.4 \%$ for those who displayed low arousal. ${ }^{34}$ The size of this effect is large (Cohen's $d=0.765)$.

In Table A.5 (Appendix A), we show that the differences in bids, in the proportion of investors who suffered the tail event and in bankruptcy rates between investors with high and low levels of baseline anticipatory arousal are significant. We define the dependent variable '\% SUFFERED TAIL EVENT' as the proportion of tail events for which an investor incurred tail losses and 'BANKRUPTCY DUMMY' as a variable taking value one if an investor went bankrupt and value zero otherwise. Table A.5 (regressions (1), (2) and (3)) shows that the coefficient for 'High Anticipatory Arousal Dummy' is negative and significant in explaining all three dependent variables. This is in line with Hypothesis 5 i.

In Figure 6, we show average earnings for the 5 sessions in which there were less than two tail events, for the 5 sessions in which there were exactly two tail events and for the 5 sessions in which there were more than two tail events. We observe that for sessions in which there were less than two tail events, earnings levels are similar for investors who displayed a high level of baseline anticipatory arousal and for those who did not. By contrast, investors who exhibited high baseline anticipatory arousal earned twice more than those who did not in sessions in which there were more than two tails events, which was the expected number of tail events in our experimental setup.

\footnotetext{
${ }^{34}$ These numbers are calculated only for those sessions in which bankruptcy was possible which is when at least two tail events were observed. This was the case in 10 out of 15 sessions.
} 


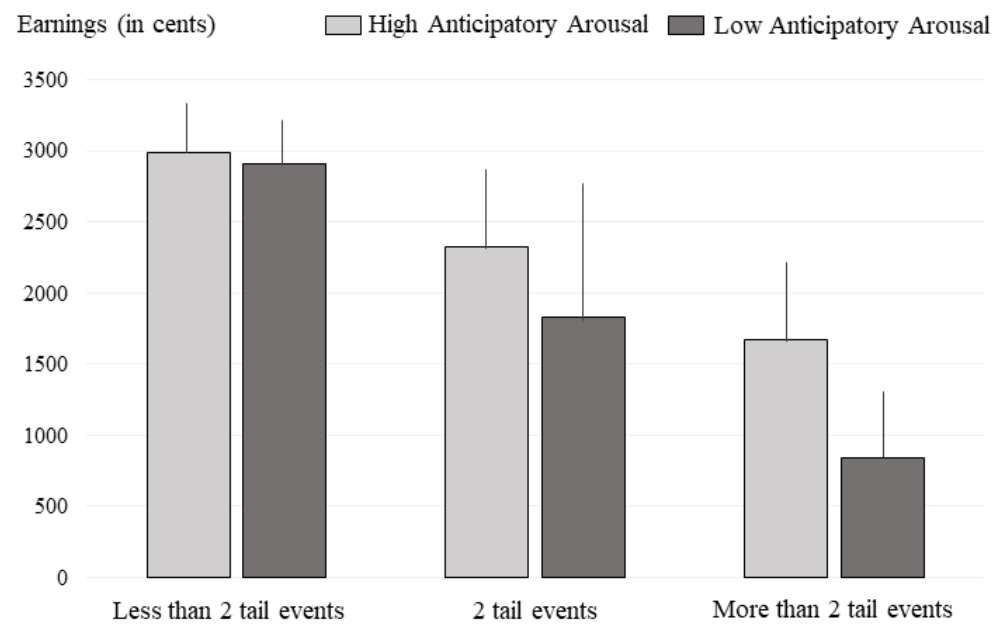

Figure 6: Average earnings of investors with high and low baseline anticipatory arousal (categorized using a median split). (Left) Sessions in which less than two tail events occurred. (Middle) Sessions in which two tail events occurred. (Right) Sessions in which more than two tail events occurred. Upper bounds of the $95 \%$ confidence intervals are displayed.

In regression (4) of Table A.5 in Appendix A, we find that the interaction coefficient 'High Anticipatory Arousal Dummy $\times$ Number of Tail Events' is positive and significant. This means that, in line with Hypothesis 5ii, the effect of baseline anticipatory arousal on earnings increases with the number of tail events. By contrast with Hypothesis 5ii, Figure 6 shows that baseline anticipatory arousal does not generally hurt investors' earnings when the number of tail events is lower than expected. However, the coefficient for the variable 'High Anticipatory Arousal Dummy' is negative and marginally significant ( $\mathrm{p}$-value $=0.089$ ) in regression (4), thus showing that, in the absence of tail events, anticipatory arousal slightly hurts investors' wealth in line with Hypothesis 5ii. Importantly, the effect of baseline anticipatory arousal on earnings is obtained even after controlling for cognitive skills, personality traits, risk, loss and ambiguity attitudes. ${ }^{35}$ Ours is the first study showing that different levels of emotional arousal can explain earnings in an investment task after controlling for a myriad of individual attributes. The only variables that explain earnings beyond baseline anticipatory arousal are risk aversion and prior beliefs about tail events 'Prior Tail Events (std)'. Risk aversion tends to predict earnings positively but this result loses significance if we drop those ten participants who never switched or switched multiple times in the Holt and Laury (2002) risk attitudes test. A high prior belief regarding the probability of occurrence of tail events, however, negatively impacts

\footnotetext{
${ }^{35}$ In particular, the emotionality score does not significantly explain earnings thus motivating further our choice of assessing emotional arousal with physiological tools rather than relying exclusively on self-reported measures.
} 
earnings but this effect seems to be due to a few participants with extreme beliefs regarding tail events. ${ }^{36}$

In sum, we find strong evidence for Hypothesis 5 according to which investors who exhibit a high level of baseline anticipatory arousal bid lower, suffer less from tail events, are less likely to go bankrupt and earn more when tail events are frequent. However, unlike Hypothesis 5, we do not find compelling evidence that investors who exhibit a high level of baseline anticipatory arousal earn less when tail events are few, thus suggesting anticipatory arousal is even more beneficial than predicted by our model. As for previous hypotheses, standard non-parametric tests confirm our results (see Online Appendix V). ${ }^{37}$

\section{Discussion}

Even though tail events are rare, their impact can be massive as is exemplified by the recent decline in stock markets worldwide in March 2020. Because tail events are, by definition, surprising, they are especially likely to trigger a strong emotional response. Our work developed a novel tail-event experimental design that allowed us to study investors' behavioral and physiological responses to tail events. We showed that tail events indeed produced a dramatic emotional reaction, which had opposite effects depending on the nature of the emotion. In particular, we found that the increase in bids observed when loss-averse investors suffered tail losses was substantially more pronounced for those who were both emotionally aroused by tail events and who were prone to anger. In cases in which the tail event was observed yet not suffered, investors who were emotionally aroused and had a hopeful personality were more likely to increase their bids, possibly out of relief, than those with a fearful personality.

In addition to studying the emotional responses to tail events, we studied the effect of anticipatory arousal, which was measured before making a decision, on investors' behavior. We found that higher anticipatory arousal decreased bids and lowered the probability of going bankrupt, which occurred when an investor suffered multiple tail losses. As a result, investors who exhibited a high level of anticipatory arousal ended up earning more money than emotionless investors in sessions with multiple tail events. This finding contrasts with the widespread view that traders should attempt to keep their emotions in check (Shefrin, 2000; Lo and Repin, 2002; Lo 2019). It turns out that emotions can have a positive or negative effect on traders' wealth depending on their nature and on the market context. Emotions tend to be beneficial when ensuring survival (i.e., avoiding bankruptcy in our case) is critical to secure financial

\footnotetext{
${ }^{36}$ If we drop the 5 participants who believed the probability of occurrence of tail events was greater than $30 \%$ then the coefficient for 'Prior Tail Events (std)' fails to reach statistical significance.

${ }^{37}$ Because our analyses in regressions (2), (3) and (4) of Table A.5 are performed at the participant's levels, we do not conduct the same robustness checks as for Hypotheses 1 to 4 regarding autocorrelation and selection effects.
} 
gains, in line with the view that emotions are adaptive (Cosmides and Tooby, 2000). By contrast, in contexts in which going bankrupt is unlikely, anticipatory arousal might lead to excessively conservative strategies not allowing investors to maximize their financial gains (Shiv et al., 2005).

Overall, our study highlights that the effect of emotions on decision-making is multifaceted. Emotions affect both beliefs and utility. Emotions of the same valence, such as anger and fear, can have opposite effects on investors' behavior. In addition, emotions, depending on their nature and on the market setup, can either hurt or boost investors' earnings. It follows that any attempt by financial authorities to regulate investors' emotions might backfire. Because our work offers specific insights on the type of emotions that are triggered by tail events and on their impact on investors' decisions, it might prompt policy makers to reflect on the emotional consequences of new regulations in times of distress. Future research could build on our experimental paradigm to study the impact of various tail-event regulations in alleviating or nurturing emotions such as fear, hope or anger. For example, circuit breakers might promote risk-averse or risk-seeking strategies depending on whether they induce fear or anger. At the trader's level, future research could look at the effectiveness of certain trading strategies, such as stop-loss orders, in protecting investors against anger-driven risk-taking behaviors.

Finally, our work suggests that financial authorities might want to infuse a certain dose of anxiety in markets to avoid escalating prices. Like any medicine, this would have to be based on extensive lab tests and handled with extreme care.

\section{References}

Aliber, R. Z., \& Kindleberger C. P. (2017). Manias, Panics, and Crashes: A History of Financial Crises. Springer.

Andersen, T. G., Fusari, N., \& Todorov, V. (2019). The pricing of tail risk and the equity premium: evidence from international option markets. Journal of Business E Economic Statistics, 1-28.

Andrade E. B., Odean T., \& Lin S. (2016). Bubbling with excitement: An experiment. Review of Finance, 20(2), 447-466.

Ashton, M. C., \& Lee, K. (2009). The HEXACO-60: A short measure of the major dimensions of personality. Journal of Personality Assessment, 91, 340-345.

Barberis, N. C. (2013a). The psychology of tail events: Progress and challenges. American Economic Review, 103(3), 611-16. 
Barberis, N. C. (2013b). Thirty years of prospect theory in economics: A review and assessment. Journal of Economic Perspectives, 27(1), 173-96.

Barberis, N., Huang, M., \& Santos, T. (2001). Prospect theory and asset prices, Quarterly Journal of Economics, 116(1), 1-53

Barro R. J. (2006). Rare disasters and asset markets in the twentieth century. Quarterly Journal of Economics, 121(3), 823-866.

Barro, R. J. (2009). Rare disasters, asset prices, and welfare costs. American Economic Review, 99(1), 243-64.

Barron G. \& Erev I. (2003). Small feedback based decisions and their limited correspondence to description based decisions. Journal of Behavioral Decision Making, 16, 215-233.

Baron-Cohen, S., Jolliffe, T., Mortimore, C., \& Robertson M. (1997). Another advanced test of theory of mind: Evidence from very high functioning adults with autism or asperger syndrome. Journal of Child Psychology and Psychiatry, 38, 813-822.

Bechara A., \& Damasio, A. R. (2005). The somatic marker hypothesis: A neural theory of economic decision, Games and Economic Behavior, 52, 336-372.

Bechara, A., Damasio, H., Tranel, D., \& Damasio, A. R. (1997). Deciding advantageously before knowing the advantageous strategy. Science, 275(5304), 1293-1295.

Becker G.M., DeGroot, M.H., \& Marschak J. (1964). Measuring utility by a single-response sequential method, Behavioral Science, 9(3), 226-232.

Bell, D. E. (1985). Disappointment in decision making under uncertainty. Operations Research, 33(1), $1-27$.

Black, F., \& Scholes, M. (1973). The pricing of options and corporate liabilities. Journal of Political Economy, 81(3), 637-654.

Blaney, P. H. (1986). Affect and memory: a review. Psychological bulletin, 99(2), 229.

Bollerslev, T., \& Todorov, V. (2011). Tails, fears, and risk premia. Journal of Finance, 66(6), 2165-2211.

Bollerslev, T., Todorov, V., \& Xu, L. (2015). Tail risk premia and return predictability. Journal of Financial Economics, 118(1), 113-134.

Boucsein, W. (2012). Electrodermal activity. Springer Science \& Business Media.

Bradley, M. M., Codispoti, M., Cuthbert, B. N., \& Lang, P. J. (2001). Emotion and motivation I: defensive and appetitive reactions in picture processing. Emotion, 1(3), 276.

Breaban A. \& Noussair C. (2018). Emotional state and market behavior. Review of Finance, 22(1), 279- 
309.

Brink, A., \& Rankin, F. (2013). The effects of risk preference and loss aversion on individual behavior under bonus, penalty, and combined contract frames. Behavioral Research in Accounting, 25(2), 145-170.

Bruguier, A., Quartz, S. \& Bossaerts P. (2010). Exploring the nature of 'trader intuition'. Journal of Finance, 65, 1703-1723.

Cacioppo, J. T., Berntson, G. G., Larsen, J. T., Poehlmann, K. M., \& Ito, T. A. (2000). The psychophysiology of emotion, in Lewis, R., Haviland-Jones, J. (Eds.), Handbook of Emotion, Ch. 11, 173-191, Guiford Press, New York.

Camerer C. F. (1987). Do biases in probability judgment matter in markets? Experimental evidence, American Economic Review, 77(5), 981-997.

Camerer C. F., \& Kunreuther H. (1989). Decision processes for low probability events: Policy implications, Journal of Policy Analysis and Management, 8(4), 565-592.

Camerer, C., Loewenstein, G., \& Prelec, D. (2005). Neuroeconomics: How neuroscience can inform economics. Journal of economic Literature, 43(1), 9-64.

Charness, G., \& Levin, D. (2005). When optimal choices feel wrong: A laboratory study of bayesian updating, complexity, and affect. American Economic Review, 95(4), 1300-1309.

Charness, G., \& Levin, D. (2009). The origin of the winner's curse: A laboratory study. American Economic Journal: Microeconomics, 1(1), 207-236.

Christopoulos, G. I., Tobler, P. N., Bossaerts, P., Dolan, R. J., \& Schultz, W. (2009). Neural correlates of value, risk, and risk aversion contributing to decision making under risk. Journal of Neuroscience, 29(40), 12574-12583.

Christopoulos, G. I., Uy, M. A., \& Yap, W. J. (2019). The body and the brain: measuring skin conductance responses to understand the emotional experience. Organizational Research Methods, 22(1), 394-420.

Cohn, A., Engelmann, J., Fehr, E., \& Maréchal, M. A. (2015). Evidence for countercyclical risk aversion: An experiment with financial professionals. American Economic Review, 105(2), 860-85.

Corgnet, B., Hernán-González, R., Kujal, P., \& Porter, D. (2015). The effect of earned versus house money on price bubble formation in experimental asset markets. Review of Finance, 19(4), 1455-1488.

Cosmides, L., \& Tooby, J. (2000). Evolutionary psychology and the emotions. Handbook of Emotions, 2(2), 91-115.

Critchley, H. D., Elliott, R., Mathias, C. J., \& Dolan, R. J. (2000). Neural activity relating to generation and representation of galvanic skin conductance responses: a functional magnetic resonance imaging study. 
Journal of Neuroscience, 20(8), 3033-3040.

Damasio A. R. (1994). Descartes' Error: Emotion, Reason, and the Human Brain, G.P. Putnam's Sons, NY.

Derakshan, N., \& Eysenck, M. W. (1997). Interpretive biases for one's own behavior and physiology in high-trait-anxious individuals and repressors. Journal of Personality and Social Psychology, 73, 816-825.

De Martino, B., O’Doherty, J., Debajyoti, R., Bossaerts, P. \& Camerer C. (2013). In the mind of the market: Theory of mind biases value computation during financial bubbles. Neuron, 79, 1222-1231.

Dimmock, S. G., Kouwenberg, R., \& Wakker, P. P. (2016). Ambiguity attitudes in a large representative sample. Management Science, 62(5), 1363-1380.

Ekman, P. (1999). Basic emotions, in Dalgleish T. and Power M. J. (Eds), Handbook of Cognition and Emotion, Ch. 3, 45-60, John Wiley \& Sons, West Sussex, England.

Erb, H. P., Bioy, A. \& Hilton, D. J. (2002). Choice preference without inferences: subconscious priming of risk attitudes. Journal of Behavioral Decision Making 15, 251-262.

Erev I. (2007). On the weighting of rare events and the economics of small decisions. Developments on Experimental Economics, 59-73.

Erev I., Ert, E., Plonsky, O., Cohen, D., \& Cohen O. (2017). From anomalies to forecasts: Toward a descriptive model of decisions under risk, under ambiguity, and from experience. Psychological Review, 24(4), 369-409.

Eysenck, M. W., \& Van Berkum, J. (1992). Trait anxiety, defensiveness, and the structure of worry. Personality and Individual Differences, 13(12), 1285-1290.

Fessler, D. M., Pillsworth, E. G., \& Flamson, T. J. (2004). Angry men and disgusted women: An evolutionary approach to the influence of emotions on risk taking. Organizational Behavior and Human Decision Processes, 95(1), 107-123.

Frederick, S. (2005). Cognitive reflection and decision making. Journal of Economic Perspectives, 19(4), 25-42.

Freixas, X., Rochet, J. C., \& Parigi, B. M. (2004). The lender of last resort: A twenty-first century approach. Journal of the European Economic Association, 2(6), 1085-1115.

Gabaix X. (2012). Variable rare disasters: An exactly solved framework for ten puzzles in macro-finance. Quarterly Journal of Economics, 127(2), 645-700.

Gilbert, D. T., \& Wilson, T. D. (2007). Prospection: Experiencing the future. Science, 317, 1351-1354.

Goetzmann, W. N., Kim, D., Kumar, A., \& Wang, Q. (2015). Weather-induced mood, institutional investors, and stock returns. Review of Financial Studies, 28(1), 73-111. 
Guiso, L., Sapienza, P., \& Zingales, L. (2018). Time varying risk aversion. Journal of Financial Economics, 128(3), 403-421.

Hertwig, R., Barron, G., Weber, E. U., \& Erev, I. (2004). Decisions from experience and the effect of rare events in risky choice. Psychological science, 15(8), 534-539.

Hirshleifer, D., \& Shumway, T. (2003) Good day sunshine: Stock returns and the weather. Journal of Finance, 58(3), 1009-1032.

Holt, C. A., \& Laury, S. K. (2002). Risk aversion and incentive effects. American Economic Review, 92(5), $1644-1655$.

Hong, S. M., \& Faedda, S. (1996). Refinement of the Hong psychological reactance scale. Educational \& Psychological Measurement, 56, 173-182.

Huber, P. (1967). The behavior of maximum likelihood estimates under nonstandard conditions. Proceedings of the Fifth Berkeley Symposium on Mathematical Statistics and Probability, 221-233.

Isen, A. M., \& Patrick, R. (1983). The effect of positive feelings on risk taking: When the chips are down. Organizational behavior and Human Performance, 31(2), 194-202.

Joffily M. (2018). Electrodermal activity (EDA) toolbox, GitHub repository, https://github.com/mateusjoffily/EDA

Joffily, M., \& Coricelli, G. (2013). Emotional valence and the free-energy principle. Plos Computational Biology, 9(6).

Johnson, E. J., \& Tversky, A. (1983). Affect, generalization, and the perception of risk. Journal of Personality and Social Psychology, 45(1), 20-31.

Kahneman, D., \& Tversky, A. (1979). Prospect theory: An analysis of decision under risk. Econometrica, 47(2), 263-291.

Kelly, B., \& Jiang, H. (2014). Tail risk and asset prices. Review of Financial Studies, 27(10), 2841-2871.

Kluger B.D., \& Wyatt S. B. (2004). Are judgment errors reflected in market prices and allocations? Experimental evidence based on the Monty Hall problem. Journal of Finance, LIX(3), 969-997.

Knutson, B., \& Bossaerts, P. (2007). Neural antecedents of financial decisions. Journal of Neuroscience, 27(31), 8174-8177.

Knutson, B., Wimmer, G. E., Kuhnen, C. M., \& Winkielman, P. (2008). Nucleus accumbens activation mediates the influence of reward cues on financial risk taking. NeuroReport, 19(5), 509-513.

Kuhnen, C. M. (2015). Asymmetric learning from financial information. Journal of Finance, 70(5), 20292062.

Kuhnen, C. M., \& Knutson, B. (2005). The neural basis of financial risk taking. Neuron, 47(5), 763-770. 
Kuhnen, C. M., \& Knutson, B. (2011). The influence of affect on beliefs, preferences, and financial decisions. Journal of Financial and Quantitative Analysis, 46(3), 605-626.

Kunreuther, H., with Ginsberg R., Miller, L., Sagi, P., Slovic, P., Borkin, B., \& Katz N. (1978). Disaster Insurance Protection: Public Policy Lessons. John Wiley and Sons, New York, NY.

Kunreuther H., \& Pauly M. (2018). Dynamic insurance decision-making for rare events: The role of emotions, Geneva Papers on Risk and Insurance, 43(2), 335-355.

Koszegi, B., Loewenstein, G., \& Murooka, T. (2019). Fragile self-esteem. Available at SSRN 3412006.

Ledoux, J. E. (1996). The emotional brain: The mysterious underpinnings of emotional life. Simon E Schuster.

Ledoux, J. E. (2012). Evolution of human emotion: a view through fear. In Progress in brain research, 195, 431-442.

Lerner, J. S., \& Keltner, D. (2001). Fear, anger, and risk. Journal of Personality and Social Psychology, 81(1), 146-159.

Lerner, J. S., Li, Y., Valdesolo, P., \& Kassam, K. S. (2015). Emotion and decision making. Annual Review of Psychology, 66, 799-823.

Lintner J. (1965). Security prices, risk, and maximal gains from diversification. Journal of Finance, 20(4), 587-615.

Lo, A. W. (2019). Adaptive markets: Financial evolution at the speed of thought. Princeton University Press.

Lo, A. W., \& Repin, D. V. (2002). The psychophysiology of real-time financial risk processing. Journal of Cognitive Neuroscience, 14(3), 323-339.

Lo, A. W., Repin, D. V., \& Steenbarger, B. N. (2005). Fear and greed in financial markets: A clinical study of day-traders. American Economic Review, 95(2), 352-359.

Loewenstein, G. F., Weber, E. U., Hsee, C. K., \& Welch, N. (2001). Risk as feelings. Psychological Bulletin, 127(2), 267.

Lopes, L. L. (1987). Between hope and fear: The psychology of risk. Advances in Experimental Social Psychology, 20(3), 255-295.

Matt, G. E., Vázquez, C., \& Campbell, W. K. (1992). Mood-congruent recall of affectively toned stimuli: A meta-analytic review. Clinical Psychology Review, 12(2), 227-255.

Markowitz H. M. (1952). Portfolio selection. Journal of Finance, 7, 77-91.

Mayer, J. D., McCormick, L. J., \& Strong, S. E. (1995). Mood-congruent memory and natural mood: New 
evidence. Personality and Social Psychology Bulletin, 21(7), 736-746.

Odean, T. (1998). Are investors reluctant to realize their losses? Journal of Finance, 53(5), 1775-1798.

Payzan-LeNestour E. (2018). Can people learn about 'black swans'? Experimental evidence, Review of Financial Studies, 31, 4815-4862.

Plonsky, O., Teodorescu, K., \& Erev, I. (2015). Reliance on small samples, the wavy recency effect, and similarity-based learning. Psychological Review, 122(4), 621-647.

Plott, C. R., \& Sunder, S. (1982). Efficiency of experimental security markets with insider information: An application of rational-expectations models. Journal of Political Economy, 90(4), 663-698.

Plott, C. R., \& Sunder, S. (1988). Rational expectations and the aggregation of diverse information in laboratory security markets. Econometrica, 56(5), 1085-1118.

Preuschoff, K., Bossaerts, P., \& Quartz, S. R. (2006). Neural differentiation of expected reward and risk in human subcortical structures. Neuron, 51(3), 381-390.

Preuschoff, K., Quartz, S. R., \& Bossaerts, P. (2008). Human insula activation reflects risk prediction errors as well as risk. Journal of Neuroscience, 28(11), 2745-2752.

Rabin M. (2002). Inference by believers in the law of small numbers. Quarterly Journal of Economics, 117(3), 775-816.

Raghunathan, R., \& Pham, M. T. (1999). All negative moods are not equal: Motivational influences of anxiety and sadness on decision making. Organizational Behavior and Human Decision Processes, 79, 56-77.

Rietz T.A. (1988). The equity risk premium: A solution. Journal of Monetary Economics, 22, 117-131.

Rottenstreich Y., \& Hsee C. K. (2001). Money, kisses, and electric shocks: On the affective psychology of risk. Psychological Science, 12(3), 185-190.

Sharpe, W. F. (1964). Capital asset prices: A theory of market equilibrium under conditions of risk. Journal of Finance, 19(3), 425-442.

Shefrin, H. (2000). Beyond greed and fear: Understanding behavioral finance and the psychology of investing. Harvard Business School Press.

Shefrin, H., \& Statman, M. (1985). The disposition to sell winners too early and ride losers too long: Theory and evidence. Journal of finance, 40(3), 777-790.

Shefrin, H. (2010). Behavioralizing finance. Foundations and Trends in Finance, 4(1-2), 1-184.

Shiller, R. J. (2015). Irrational exuberance: Revised and expanded third edition. Princeton University Press.

Shiv, B., Loewenstein, G., Bechara, A., Damasio, H., \& Damasio, A. R. (2005). Investment behavior and 
the negative side of emotion. Psychological Science, 16(6), 435-439.

Slovic, P., Finucane, M. L., Peters, E., \& MacGregor, D. G. (2007). The affect heuristic. European Journal of Operational Research, 177(3), 1333-1352.

Smith, V. L., Suchanek, G. L., Williams, A. W. (1988) Bubbles, crashes, and endogenous expectations in experimental spot asset markets. Econometrica, 56(5), 1119-1151.

Stott, H. P. (2006) Cumulative prospect theory's functional menagerie. Journal of Risk and Uncertainty, $32,101-130$.

Taleb, N. N. (2007). The Black Swan: The Impact of the Highly Improbable. Random House.

Thaler, R. H., \& Johnson, E. J. (1990). Gambling with the house money and trying to break even: The effects of prior outcomes on risky choice. Management Science, 36(6), 643-660.

Tobin, J. (1958). Liquidity preference as behavior towards risk. Review of Economic Studies, 25(2), 65-86.

Toplak, M., West, R., \& Stanovich K. (2014). Assessing miserly information processing: An expansion of the cognitive reflection test. Thinking E Reasoning, 20(2), 147-168.

Tversky, A., \& Kahneman, D. (1973). Availability: A heuristic for judging frequency and probability. Cognitive Psychology, 5(2), 207-232.

Tversky, A., \& Kahneman, D. (1974). Judgment under uncertainty: Heuristics and biases. Science, 185(4157), 1124-1131.

Tversky, A., \& Kahneman, D. (1992). Advances in prospect theory: Cumulative representation of uncertainty. Journal of Risk and Uncertainty, 5(4), 297-323.

van Well, S., O'Doherty, J. P., \& van Winden, F. (2019). Relief from incidental fear evokes exuberant risk taking. PloS one, 14(1).

Watkins, P. C., Mathews, A., Williamson, D. A., \& Fuller, R. D. (1992). Mood-congruent memory in depression: Emotional priming or elaboration? Journal of Abnormal Psychology, 101(3), 581-586.

Watkins, P. C., Vache, K., Verney, S. P., Muller, S., \& Mathews, A. (1996). Unconscious mood-congruent memory bias in depression. Journal of Abnormal Psychology, 105(1), 34-41.

White, H. (1980). A heteroskedasticity-consistent covariance matrix estimator and a direct test for heteroskedasticity. Econometrica. 48(4), 817-838. 


\section{A Supplementary Material}
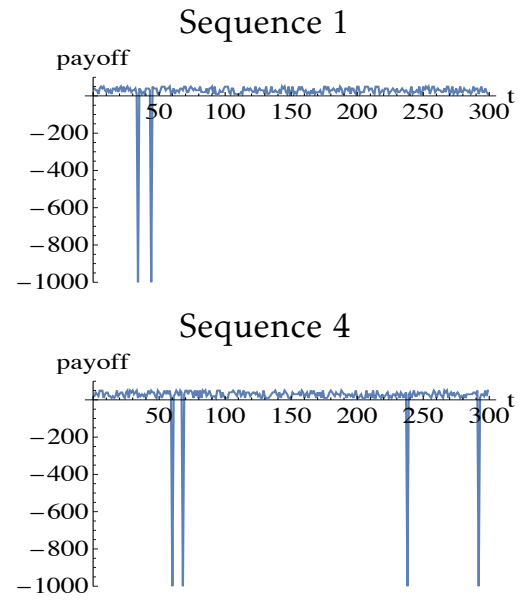

Sequence 7
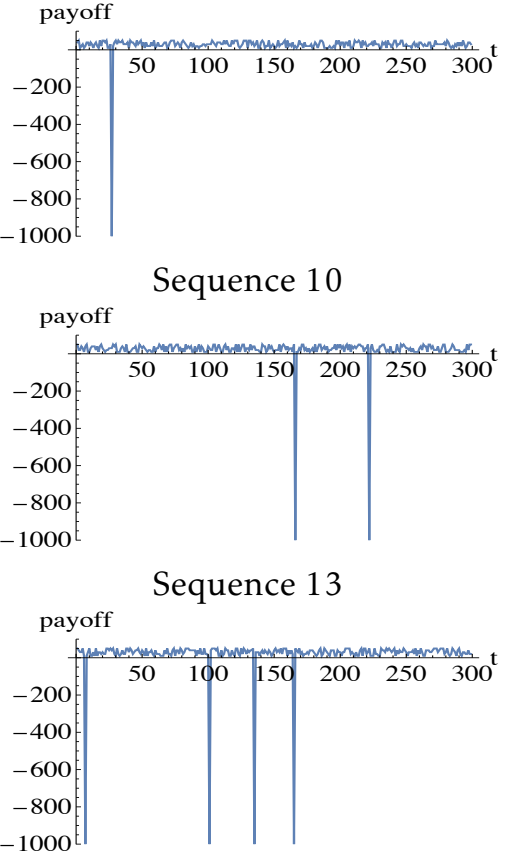

Sequence 2

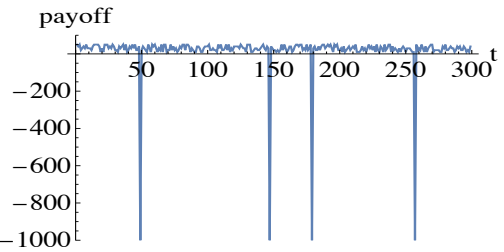

Sequence 5

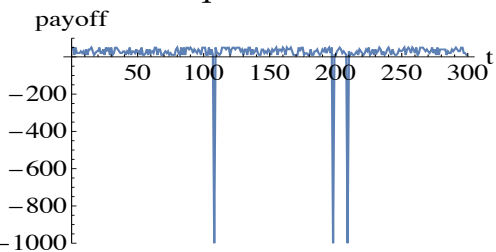

Sequence 8

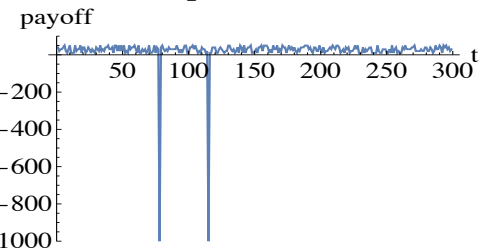

Sequence 11

payoff

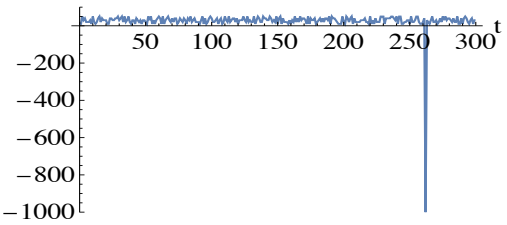

$-1000$

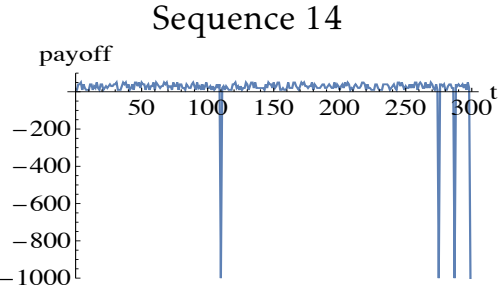

Sequence 3

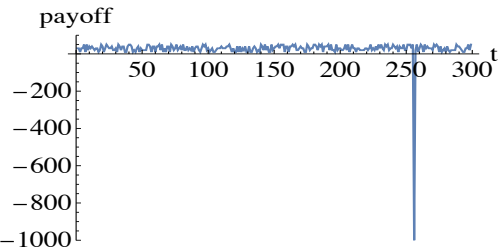

Sequence 6

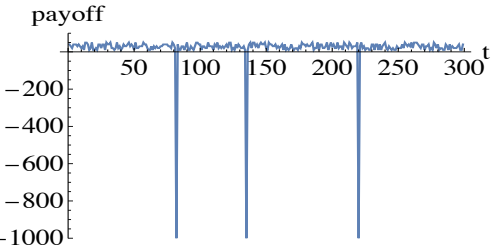

Sequence 9

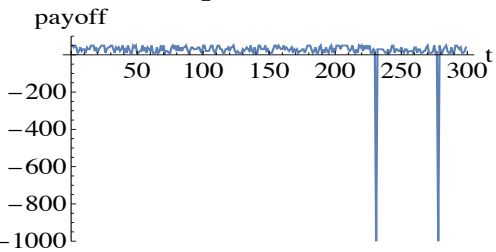

Sequence 12

payoff

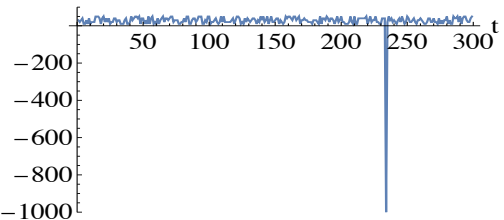

Sequence 15

payoff

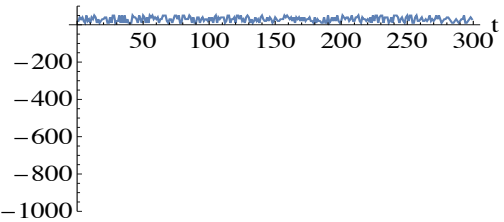

Figure A.1: Actual sequence of token draws for all 15 sessions. 


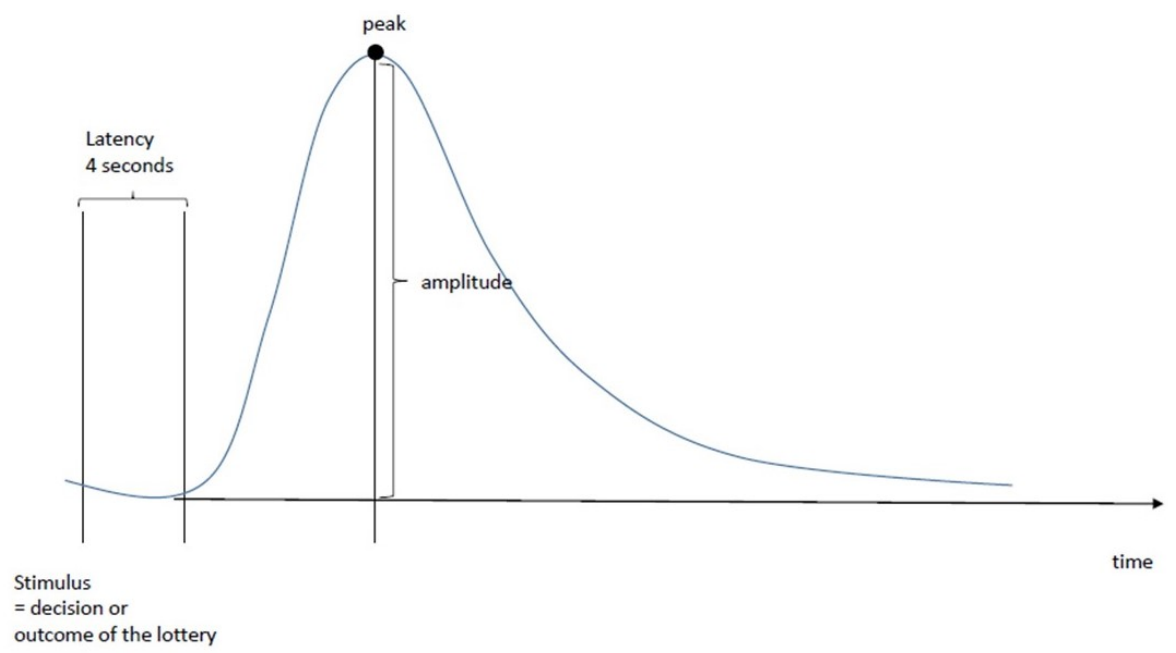

Figure A.2: Typical shape of event-related electrodermal activity (Christopoulos et al., 2019)

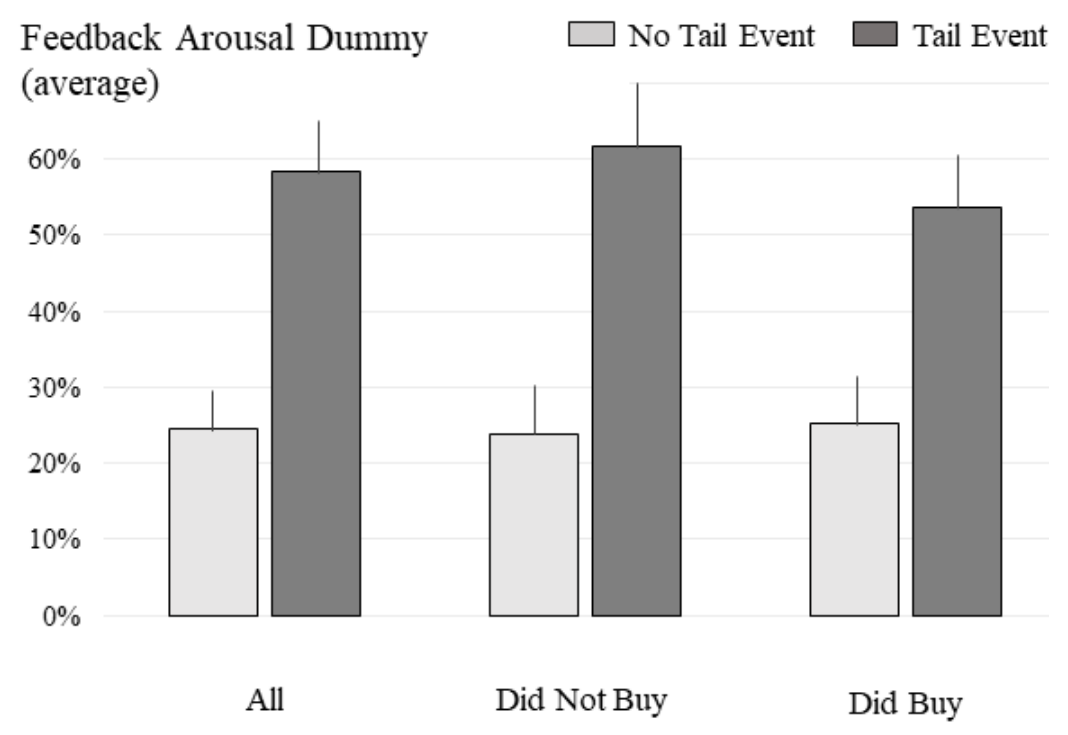

Figure A.3: Percentage of investors who displayed feedback arousal after observing a tail or a non-tail event whether they bought the asset (Did Buy) or not (Did Not Buy). Upper bounds of the 95\% confidence intervals are displayed. 
Table A.1: Stable Dummy and Tail Events. Panel probit regressions with random effects and robust standard errors clustered at the individual levels in parentheses, session fixed effects included.

\begin{tabular}{llll}
\hline VARIABLE & \multicolumn{3}{l}{ STABLE DUMMY } \\
\hline \multirow{2}{*}{ SAMPLE } & $(1)$ & $(2)$ & $(3)$ \\
& $\begin{array}{l}\text { Investors did not } \\
\text { buy asset in pre- } \\
\text { vious period }\end{array}$ & $\begin{array}{l}\text { Investors bought } \\
\text { asset in previous } \\
\text { period }\end{array}$ & \\
& $\mathbf{- 0 . 1 9 9}$ & $\mathbf{- 0 . 2 3 5}$ & $\mathbf{- 0 . 2 1 4}$ \\
& $\mathbf{( 0 . 1 7 4 )}$ & $\mathbf{( 0 . 2 0 8 )}$ & $\mathbf{( 0 . 1 3 8 )}$ \\
\hline \hline Tail Event Dummy & $0.004^{* * *}$ & $0.004^{* * *}$ & $0.004^{* * *}$ \\
Period & $(0.001)$ & $(0.001)$ & $(0.001)$ \\
& -0.084 & -0.108 & -0.091 \\
Number of Tail Events & $(0.060)$ & $(0.067)$ & $(0.056)$ \\
Constant & -0.527 & -0.387 & -0.443 \\
& $(0.434)$ & $(0.540)$ & $(0.468)$ \\
\hline Observations & 13,793 & 13,793 & 13,793 \\
Number of Investors & 86 & 86 & 86 \\
\hline
\end{tabular}

${ }^{* * *} \mathrm{p}<0.01,{ }^{* *} \mathrm{p}<0.05,{ }^{*} \mathrm{p}<0.1$

The stable dummy takes value one if an investor's bid is the same as in the previous period. 
Table A.2: Decrease in Bids, Hope and Fear. Panel probit regressions with random effects and robust standard errors clustered at the individual levels in parentheses, session fixed effects included.

\begin{tabular}{|c|c|c|c|c|}
\hline VARIABLE & & DOWN & JUMMY & \\
\hline $\begin{array}{l}\text { SAMPLE } \\
\text { (Investors did not buy as- } \\
\text { set in previous period) }\end{array}$ & $\begin{array}{l}\text { (1) } \\
\text { Hopeful \& } \\
\text { Not fearful }\end{array}$ & $\begin{array}{l}(2) \\
\text { Fearful \& } \\
\text { Not Hopeful }\end{array}$ & (3) & $\begin{array}{l}(4) \\
\text { High Avail- } \\
\text { ability Bias }\end{array}$ \\
\hline Tail Event Dummy & $\begin{array}{l}0.603^{*} \\
(0.363)\end{array}$ & $\begin{array}{l}0.302 \\
(0.338)\end{array}$ & $\begin{array}{l}0.259 \\
(0.338)\end{array}$ & $\begin{array}{l}0.169 \\
(0.507)\end{array}$ \\
\hline Hopeful Dummy & - & - & $\begin{array}{l}-0.226 \\
(0.210)\end{array}$ & $\begin{array}{l}-0.378 \\
(0.283)\end{array}$ \\
\hline $\begin{array}{l}\text { Feedback } \\
\text { Dummy }\end{array}$ & $\begin{array}{l}0.066 \\
(0.073)\end{array}$ & $\begin{array}{l}0.034 \\
(0.069)\end{array}$ & $\begin{array}{l}0.017 \\
(0.068)\end{array}$ & $\begin{array}{l}-0.082 \\
(0.102)\end{array}$ \\
\hline $\begin{array}{l}\text { Tail Event } \times \text { Feedback } \\
\text { Arousal Dummy }\end{array}$ & $\begin{array}{l}-0.829^{*} \\
(0.485)\end{array}$ & $\begin{array}{l}0.327 \\
(0.570)\end{array}$ & $\begin{array}{l}0.349 \\
(0.562)\end{array}$ & $\begin{array}{l}1.246 \\
(0.766)\end{array}$ \\
\hline $\begin{array}{l}\text { Tail Event } \times \text { Hopeful } \\
\text { Dummy }\end{array}$ & - & - & $\begin{array}{l}0.353 \\
(0.482)\end{array}$ & $\begin{array}{l}0.625 \\
(0.616)\end{array}$ \\
\hline $\begin{array}{l}\text { Feedback Arousal } \times \\
\text { Hopeful Dummy }\end{array}$ & - & - & $\begin{array}{l}0.055 \\
(0.097)\end{array}$ & $\begin{array}{l}0.170 \\
(0.146)\end{array}$ \\
\hline 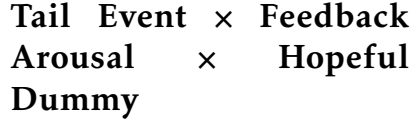 & - & - & $\begin{array}{l}-1.179 \\
0.733\end{array}$ & $\begin{array}{l}-2.382^{* * *} \\
(0.927)\end{array}$ \\
\hline Period & $\begin{array}{l}-0.002^{*} \\
(0.001)\end{array}$ & $\begin{array}{l}0.000 \\
(0.001)\end{array}$ & $\begin{array}{l}-0.001 \\
(0.001)\end{array}$ & $\begin{array}{l}-0.000 \\
(0.001)\end{array}$ \\
\hline Number of Tail Events & $\begin{array}{l}0.048 \\
(0.067)\end{array}$ & $\begin{array}{l}-0.077 \\
(0.064)\end{array}$ & $\begin{array}{l}-0.016 \\
(0.047)\end{array}$ & $\begin{array}{l}-0.054 \\
(0.064)\end{array}$ \\
\hline Constant & $\begin{array}{l}-1.069^{* * *} \\
(0.055)\end{array}$ & $\begin{array}{l}-0.478^{* * *} \\
(0.135)\end{array}$ & $\begin{array}{l}-0.451^{\star * \star} \\
(0.129)\end{array}$ & $\begin{array}{l}-0.337^{\star *} \\
(0.166) \\
\end{array}$ \\
\hline Observations & 4,959 & 3,494 & 8,453 & 4,623 \\
\hline Number of investors & 29 & 21 & 50 & 28 \\
\hline
\end{tabular}

${ }^{* * *} \mathrm{p}<0.01,{ }^{* *} \mathrm{p}<0.05,{ }^{*} \mathrm{p}<0.1$ 
Table A.3: Increase in Bids, Tail Losses, Hope and Fear. Panel probit regressions with random effects and robust standard errors clustered at the individual levels in parentheses, session fixed effects included.

\begin{tabular}{|c|c|c|c|c|}
\hline VARIABLE & & UP D & JMMY & \\
\hline $\begin{array}{l}\text { SAMPLE } \\
\text { (Investors bought asset in } \\
\text { previous period) }\end{array}$ & $\begin{array}{l}\text { (1) } \\
\text { Hopeful \& } \\
\text { Not fearful }\end{array}$ & $\begin{array}{l}(2) \\
\text { Fearful \& } \\
\text { Not Hopeful }\end{array}$ & (3) & $\begin{array}{l}(4) \\
\text { High Avail- } \\
\text { ability Bias }\end{array}$ \\
\hline Tail Event Dummy & $\begin{array}{l}-4.947^{\star * *} \\
(0.162)\end{array}$ & $\begin{array}{l}0.220 \\
(0.563)\end{array}$ & $\begin{array}{l}0.180 \\
(0.555)\end{array}$ & $\begin{array}{l}0.594 \\
(0.712)\end{array}$ \\
\hline Hopeful Dummy & - & - & $\begin{array}{l}-0.381 \\
(0.248)\end{array}$ & $\begin{array}{l}-0.707^{* * *} \\
(0.271)\end{array}$ \\
\hline $\begin{array}{l}\text { Feedback } \\
\text { Dummy }\end{array}$ & $\begin{array}{l}-0.041 \\
(0.087)\end{array}$ & $\begin{array}{l}0.080 \\
(0.063)\end{array}$ & $\begin{array}{l}0.060 \\
(0.065)\end{array}$ & $\begin{array}{l}-0.029 \\
(0.146)\end{array}$ \\
\hline $\begin{array}{l}\text { Tail Event } \times \text { Feedback } \\
\text { Arousal Dummy }\end{array}$ & $\begin{array}{l}5.586^{* * *} \\
(0.427)\end{array}$ & $\begin{array}{l}0.361 \\
(0.882)\end{array}$ & $\begin{array}{l}0.410 \\
(0.867)\end{array}$ & $\begin{array}{l}-5.701^{* * *} \\
(0.812)\end{array}$ \\
\hline $\begin{array}{l}\text { Tail Event } \times \text { Hopeful } \\
\text { Dummy }\end{array}$ & - & - & $\begin{array}{l}-4.893^{\star * *} \\
(0.575)\end{array}$ & $\begin{array}{l}-5.292^{* * *} \\
(0.754)\end{array}$ \\
\hline $\begin{array}{l}\text { Feedback Arousal } \times \\
\text { Hopeful Dummy }\end{array}$ & - & - & $\begin{array}{l}-0.092 \\
(0.110)\end{array}$ & $\begin{array}{l}-0.006 \\
(0.175)\end{array}$ \\
\hline 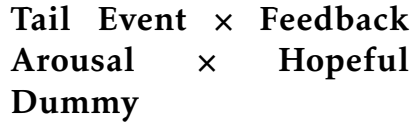 & - & - & $\begin{array}{l}4.972^{* * *} \\
(0.964)\end{array}$ & $\begin{array}{l}10.760^{* * *} \\
(1.088)\end{array}$ \\
\hline Period & $\begin{array}{l}0.000 \\
(0.001)\end{array}$ & $\begin{array}{l}-0.001 \\
(0.001)\end{array}$ & $\begin{array}{l}-0.001 \\
(0.001)\end{array}$ & $\begin{array}{l}-0.000 \\
(0.001)\end{array}$ \\
\hline Number of Tail Events & $\begin{array}{l}-0.043 \\
(0.067)\end{array}$ & $\begin{array}{l}0.054 \\
(0.094)\end{array}$ & $\begin{array}{l}-0.001 \\
(0.057)\end{array}$ & $\begin{array}{l}-0.030 \\
(0.095)\end{array}$ \\
\hline Constant & $\begin{array}{l}-0.645^{* * *} \\
(0.225)\end{array}$ & $\begin{array}{l}-1.039^{* * *} \\
(0.067)\end{array}$ & $\begin{array}{l}-0.610^{* * *} \\
(0.208)\end{array}$ & $\begin{array}{c}-0.467^{\star} \\
(0.270)\end{array}$ \\
\hline Observations & 2,557 & 3,174 & 5,731 & 2,902 \\
\hline Number of investors & 21 & 29 & 50 & 27 \\
\hline
\end{tabular}

${ }^{* * *} \mathrm{p}<0.01,{ }^{* *} \mathrm{p}<0.05,{ }^{*} \mathrm{p}<0.1$ 
Table A.4: Increase in Bids, Tail Losses, Emotional Arousal and Anger. Panel probit regressions with random effects and robust standard errors clustered at the individual levels in parentheses, session fixed effects included.

\begin{tabular}{|c|c|c|c|c|c|c|}
\hline VARIABLE & & & $\mathrm{UP}$ & MMY & & \\
\hline $\begin{array}{l}\text { SAMPLE } \\
\text { Fearful \& not hopeful in- } \\
\text { vestors (PT investors who } \\
\text { bought asset in previous } \\
\text { period) }\end{array}$ & $\begin{array}{l}(1) \\
\text { No feedback } \\
\text { arousal }\end{array}$ & $\begin{array}{l}(2) \\
\text { Feedback } \\
\text { arousal }\end{array}$ & (3) & $\begin{array}{l}4) \\
\text { Anger- } \\
\text { prone }\end{array}$ & $\begin{array}{l}\text { (5) } \\
\text { Not anger- } \\
\text { prone }\end{array}$ & (6) \\
\hline Tail Event Dummy & $\begin{array}{l}-0.233 \\
(0.674)\end{array}$ & $\begin{array}{l}0.710 \\
(0.472)\end{array}$ & $\begin{array}{l}-0.287 \\
(0.693)\end{array}$ & $\begin{array}{l}-4.991^{* * *} \\
(0.300)\end{array}$ & $\begin{array}{l}0.483 \\
(0.958)\end{array}$ & $\begin{array}{l}0.391 \\
(0.934)\end{array}$ \\
\hline $\begin{array}{l}\text { Feedback } \quad \text { Arousal } \\
\text { Dummy }\end{array}$ & - & - & $\begin{array}{l}0.026 \\
(0.076)\end{array}$ & $\begin{array}{l}0.125 \\
(0.129)\end{array}$ & $\begin{array}{l}-0.073 \\
(0.097)\end{array}$ & $\begin{array}{l}-0.124 \\
(0.107)\end{array}$ \\
\hline $\begin{array}{l}\text { Tail Event } \times \text { Feedback } \\
\text { Arousal Dummy }\end{array}$ & - & - & $\begin{array}{l}1.159 \\
(1.040)\end{array}$ & $\begin{array}{l}6.745^{* * *} \\
(0.484)\end{array}$ & $\begin{array}{l}0.058 \\
(1.609)\end{array}$ & $\begin{array}{l}0.224 \\
(1.384)\end{array}$ \\
\hline $\begin{array}{l}\text { Tail Event } \times \text { Feedback } \\
\text { Arousal } \times \text { Anger Dummy }\end{array}$ & - & - & - & - & - & $\begin{array}{l}5.807^{\star * *} \\
(1.469)\end{array}$ \\
\hline $\begin{array}{l}\text { Tail Event } \times \text { Anger } \\
\text { Dummy }\end{array}$ & - & - & - & - & - & $\begin{array}{l}-4.778^{* * *} \\
(0.965)\end{array}$ \\
\hline $\begin{array}{l}\text { Feedback Arousal } \times \text { Anger } \\
\text { Dummy }\end{array}$ & - & - & - & - & - & $\begin{array}{l}0.277 \\
(0.184)\end{array}$ \\
\hline Anger Dummy & - & - & - & - & - & $\begin{array}{l}-0.019 \\
(0.189)\end{array}$ \\
\hline Period & $\begin{array}{l}0.001 \\
(0.001)\end{array}$ & $\begin{array}{l}-0.001 \\
(0.002)\end{array}$ & $\begin{array}{l}0.000 \\
(0.001)\end{array}$ & $\begin{array}{l}0.000 \\
(0.001)\end{array}$ & $\begin{array}{l}0.001 \\
(0.002)\end{array}$ & $\begin{array}{l}0.000 \\
(0.001)\end{array}$ \\
\hline Number of Tail Events & $\begin{array}{l}-0.132 \\
(0.091)\end{array}$ & $\begin{array}{l}0.066 \\
(0.134)\end{array}$ & $\begin{array}{l}-0.073 \\
(0.080)\end{array}$ & $\begin{array}{l}-0.071 \\
(0.136)\end{array}$ & $\begin{array}{l}-0.123 \\
(0.176)\end{array}$ & $\begin{array}{l}-0.080 \\
(0.081)\end{array}$ \\
\hline Constant & $\begin{array}{l}-0.858^{* * *} \\
(0.108)\end{array}$ & $\begin{array}{l}-0.650^{*} \\
(0.333)\end{array}$ & $\begin{array}{l}-0.824^{* * *} \\
(0.102)\end{array}$ & $\begin{array}{l}-0.772^{* * *} \\
(0.260)\end{array}$ & $\begin{array}{l}-0.879^{* * *} \\
(0.125)\end{array}$ & $\begin{array}{l}-0.824^{\star * \star} \\
(0.159)\end{array}$ \\
\hline Observations & 1,255 & 494 & 1,749 & 962 & 787 & 1,749 \\
\hline Number of Investors & 15 & 15 & 15 & 8 & 7 & 15 \\
\hline
\end{tabular}

${ }^{* * *} \mathrm{p}<0.01,{ }^{* *} \mathrm{p}<0.05,{ }^{*} \mathrm{p}<0.1$ 
Table A.5: Bids, Bankruptcy, Earnings and Anticipatory Arousal. (1) Panel linear with random effects, (2) GLM, (3), Probit, (4) OLS regressions with robust standard errors clustered at the individual levels in parentheses, session fixed effects included.

\begin{tabular}{|c|c|c|c|c|}
\hline VARIABLES & $\begin{array}{l}(1) \\
\text { BIDS (in } \varnothing)\end{array}$ & $\begin{array}{l}\text { (2) } \\
\% \text { SUFFERED } \\
\text { TAIL EVENT }\end{array}$ & $\begin{array}{l}\text { (3) } \\
\text { BANKRUPTCY } \\
\text { DUMMY }\end{array}$ & $\begin{array}{l}(4) \\
\text { EARNINGS } \\
(\text { in } \notin)\end{array}$ \\
\hline $\begin{array}{l}\text { High Anticipatory Arousal } \\
\text { Dummy }\end{array}$ & $\begin{array}{l}-3.714^{* *} \\
(1.804)\end{array}$ & $\begin{array}{l}-1.596^{* * *} \\
(0.485)\end{array}$ & $\begin{array}{l}-1.550^{* * *} \\
(0.519)\end{array}$ & $\begin{array}{l}-474.834^{*} \\
(274,648)\end{array}$ \\
\hline $\begin{array}{l}\text { High Anticipatory Arousal } \\
\text { Dummy } \times \text { Number of Tail } \\
\text { Events }\end{array}$ & - & - & - & $\begin{array}{l}303.025^{* * *} \\
(108.961)\end{array}$ \\
\hline Male Dummy (std) & $\begin{array}{l}-0.347 \\
(1.200)\end{array}$ & $\begin{array}{l}0.011 \\
(0.263)\end{array}$ & $\begin{array}{l}0.372 \\
(0.239)\end{array}$ & $\begin{array}{l}-46.251 \\
(89.534)\end{array}$ \\
\hline Availability Index (std) & $\begin{array}{l}-0.466 \\
(0.793)\end{array}$ & $\begin{array}{l}0.159 \\
(0.256)\end{array}$ & $\begin{array}{l}-0.0281 \\
(0.290)\end{array}$ & $\begin{array}{l}-35.391 \\
(70.159)\end{array}$ \\
\hline Loss Aversion (std) & $\begin{array}{l}-0.209 \\
(0.866)\end{array}$ & $\begin{array}{l}-0.320 \\
(0.233)\end{array}$ & $\begin{array}{l}-0.158 \\
(0.269)\end{array}$ & $\begin{array}{l}41.625 \\
(66.316)\end{array}$ \\
\hline Risk Aversion (std) & $\begin{array}{l}-0.132 \\
(0.871)\end{array}$ & $\begin{array}{l}-0.476^{* *} \\
(0.225)\end{array}$ & $\begin{array}{l}-0.247 \\
(0.222)\end{array}$ & $\begin{array}{l}118.066^{*} \\
(62.237)\end{array}$ \\
\hline Ambiguity Aversion (std) & $\begin{array}{l}-0.646^{*} \\
(0.356)\end{array}$ & $\begin{array}{l}-0.044 \\
(0.099)\end{array}$ & $\begin{array}{l}-0.091 \\
(0.101)\end{array}$ & $\begin{array}{l}-3.458 \\
(30.055)\end{array}$ \\
\hline Bayesian Updating Score (std) & $\begin{array}{l}-2.478^{* *} \\
(0.967)\end{array}$ & $\begin{array}{l}-0.283 \\
(0.219)\end{array}$ & $\begin{array}{l}-0.073 \\
(0.220)\end{array}$ & $\begin{array}{l}-44.444 \\
(67.598)\end{array}$ \\
\hline CRT score (std) & $\begin{array}{l}-0.532 \\
(0.813)\end{array}$ & $\begin{array}{l}0.0975 \\
(0.194)\end{array}$ & $\begin{array}{l}-0.127 \\
(0.232)\end{array}$ & $\begin{array}{l}68.289 \\
(70.857)\end{array}$ \\
\hline Emotionality Score (std) & $\begin{array}{l}1.068 \\
(0.914)\end{array}$ & $\begin{array}{l}0.180 \\
(0.236)\end{array}$ & $\begin{array}{l}-0.097 \\
(0.231)\end{array}$ & $\begin{array}{l}35.594 \\
(78.613)\end{array}$ \\
\hline Prior Tail Events (std) & $\begin{array}{l}-0.380 \\
(0.866)\end{array}$ & $\begin{array}{l}0.0745 \\
(0.229)\end{array}$ & $\begin{array}{l}0.0912 \\
(0.190)\end{array}$ & $\begin{array}{l}-171.820^{*} \\
(91.376)\end{array}$ \\
\hline Number of Tail Events & $\begin{array}{l}-1.814^{* * *} \\
(0.406)\end{array}$ & - & $\begin{array}{l}-0.0980 \\
(0.292)\end{array}$ & $\begin{array}{l}808.934^{* * *} \\
(247.659)\end{array}$ \\
\hline Constant & $\begin{array}{l}26.163^{* * *} \\
(4.081)\end{array}$ & $\begin{array}{l}-2.049^{*} \\
(1.050)\end{array}$ & $\begin{array}{l}-0.062 \\
(0.819)\end{array}$ & $\begin{array}{l}1,361.183^{* *} \\
(543.836)\end{array}$ \\
\hline Observations & 23,048 & 78 & 55 & 84 \\
\hline R-squared & 0.244 & - & - & 0.889 \\
\hline R-squared (pseudo) & - & - & 0.269 & - \\
\hline
\end{tabular}

(std) refers to standardized variables.

${ }^{* * *} \mathrm{p}<0.01,{ }^{* *} \mathrm{p}<0.05,{ }^{*} \mathrm{p}<0.1$

The number of observations in regression (1) is the number of instances in which a non-bankrupt investor posted a bid (after the first 5 periods used to measure anticipatory arousal). In (2), it is the number of investors who suffered at least one tail event. In (3) it is the number of investors who suffered at least two tail events and in (4) it is the total number of participants. 


\section{Online Appendix}

The online appendix is organized as follows:

I. Instructions

II. Simulations

III. Robustness Checks for Hypotheses

IV. Robustness Checks for Results

V. Non-parametric tests 


\section{Instructions}

Sentences in italics are for the readers and not shown to participants.

\section{I.1 SPECIFIC INSTRUCTIONS FOR PARTICIPANTS IN DAY 1 SESSION (on screen)}

Welcome.

Thank you for participating in this experiment.

Please turn off your phone. It is forbidden to talk to other participants throughout the session.

If at any time during the session you need help, press the red button on the left of your desk or raise your hand, we will immediately come to answer your questions in private.

You have registered to participate in two experimental sessions.

During this first experimental session, we ask you to perform a series of tests on the computer.

You will be paid to do these tests. This payoff will be added to your total earnings at the end of the second experimental session.

In this first part, you will answer 12 blocks of questions.

Please answer the following questions as best as you can.

Calculators, paper and pen are not allowed.

\section{Block 1 \\ Bayesian updating}

Following Charness and Levin (2009) we use the following test to assess participants' Bayesian skills.

Consider two machines placed on either side of a large production room in a factory, left side (L) and right side (R). Both machines produce rings of good or poor quality. Each ring coming from the machine on the left (L) has a 50\% chance of being of good quality and a $50 \%$ chance of being of poor quality. Each ring from the right machine $(\mathrm{R})$ has a $75 \%$ chance of being of good quality and a $25 \%$ chance of being of poor quality.

In each of the next four questions, you will observe a few rings produced by one of the two machines (L or R). You will be asked how likely it is that these rings were produced by the left-hand machine (L). You will receive $50 \notin$ for each correct answer.

Question 1. You are looking at a good quality ring. How likely do you think it is that this ring was produced by the machine on the left (L) (select your answer below)?

\begin{tabular}{|l|l|l|l|l|l|l|l|l|l|l|}
\hline $100 \%$ & $90 \%$ & $80 \%$ & $70 \%$ & $60 \%$ & $50 \%$ & $40 \%$ & $30 \%$ & $20 \%$ & $10 \%$ & $0 \%$ \\
\hline
\end{tabular}

Question 2. You are looking at a poor quality ring. How likely do you think it is that this ring was produced by the machine on the left (L) (select your answer below)?

\begin{tabular}{|l|l|l|l|l|l|l|l|l|l|l|}
\hline $100 \%$ & $90 \%$ & $80 \%$ & $70 \%$ & $60 \%$ & $50 \%$ & $40 \%$ & $30 \%$ & $20 \%$ & $10 \%$ & $0 \%$ \\
\hline
\end{tabular}


Question 3. You are looking at six rings, all of which are of poor quality. How likely do you think it is that these rings were produced by the machine on the left (L) (select your answer below)?

\begin{tabular}{|l|l|l|l|l|l|l|l|l|l|l|}
\hline $100 \%$ & $90 \%$ & $80 \%$ & $70 \%$ & $60 \%$ & $50 \%$ & $40 \%$ & $30 \%$ & $20 \%$ & $10 \%$ & $0 \%$ \\
\hline
\end{tabular}

Question 4. You observe six rings, three of which are of good quality and three of poor quality. How likely do you think it is that these rings were produced by the machine on the left (L) (select your answer below)?

\begin{tabular}{|l|l|l|l|l|l|l|l|l|l|l|}
\hline $100 \%$ & $90 \%$ & $80 \%$ & $70 \%$ & $60 \%$ & $50 \%$ & $40 \%$ & $30 \%$ & $20 \%$ & $10 \%$ & $0 \%$ \\
\hline
\end{tabular}

This test was incentivized: participants received 0.5 euros for each correct answer. The average earning is 0.41 euro (minimum earning: 0 euro; maximum earning: 2 euros).

Table I.1: Distribution of Bayesian updating scores

\begin{tabular}{|c|c|}
\hline Bayesian updating scores & \% of participants \\
\hline 0 & 44.19 \\
\hline 1 & 33.72 \\
\hline 2 & 19.77 \\
\hline 3 & 1.16 \\
\hline 4 & 1.16 \\
\hline Mean & 0.81 \\
\hline Standard deviation & 0.87 \\
\hline
\end{tabular}

The Bayesian updating score corresponds to the number of correct answers.

\section{Block 2 \\ Risk aversion}

Following Holt and Laury (2002) we use the following risk aversion test.

For each line of the table presented on the following screen, indicate whether you prefer option A or option B.

Note that there is a total of 10 lines in the table, but only one line will be randomly selected to compute your payoffs. As all lines are equally likely to be selected for the computation of your payoffs, you should attribute the same importance to each of your decisions.

At the end of the experiment, a number between 1 and 10 will be randomly selected by the computer. This number will determine which line will be used to compute your payoffs. Your payoff for the selected line thus depends on the option that you will have chosen for this line: option A or option B. To finalize the computation of your payoffs, a second number between 1 and 10 will also be randomly selected by the computer.

- For example, if the first number selected by the computer is 3, this indicates that line 3 will be chosen for the computation of your payoffs. If for this line you have chosen option A, you will earn 2 euros 
if the second number randomly selected by the computer is 1,2 or 3 . If the second selected number is $4,5,6,7,8,9$ or 10 , you will earn 1.60 euros.

- For example, if the first number selected by the computer is 5 , this indicates that line 5 will be chosen for the computation of your payoffs. If for this line you have chosen option B, you will earn 3.85 euros if the second number randomly selected by the computer is $1,2,3,4$ or 5 . If the second selected number is $6,7,8,9$ or 10 , you will earn 0.10 euros.

Once on the decision screen, you can always come back to the present instructions screen by clicking on Instructions.

\begin{tabular}{|c|c|c|c|c|}
\hline Decision & Option A & Option B & \multicolumn{2}{|c|}{ Option choice } \\
\hline 1 & $\begin{array}{l}10 \% \text { of earning } 2.0 \text { euros } \\
90 \% \text { of earning } 1.6 \text { euros }\end{array}$ & $\begin{array}{l}10 \% \text { of earning } 3.85 \text { euros } \\
90 \% \text { of earning } 0.1 \text { euros }\end{array}$ & - Option A & - Option B \\
\hline 2 & $\begin{array}{l}20 \% \text { of earning } 2.0 \text { euros } \\
80 \% \text { of earning } 1.6 \text { euros }\end{array}$ & $\begin{array}{l}20 \% \text { of earning } 3.85 \text { euros } \\
80 \% \text { of earning } 0.1 \text { euros }\end{array}$ & - Option A & - Option B \\
\hline 3 & $\begin{array}{l}30 \% \text { of earning } 2.0 \text { euros } \\
70 \% \text { of earning } 1.6 \text { euros }\end{array}$ & $\begin{array}{l}30 \% \text { of earning } 3.85 \text { euros } \\
70 \% \text { of earning } 0.1 \text { euros }\end{array}$ & - Option A & - Option B \\
\hline 4 & $\begin{array}{l}40 \% \text { of earning } 2.0 \text { euros } \\
60 \% \text { of earning } 1.6 \text { euros }\end{array}$ & $\begin{array}{l}40 \% \text { of earning } 3.85 \text { euros } \\
60 \% \text { of earning } 0.1 \text { euros }\end{array}$ & - Option A & - Option B \\
\hline 5 & $\begin{array}{l}50 \% \text { of earning } 2.0 \text { euros } \\
50 \% \text { of earning } 1.6 \text { euros }\end{array}$ & $\begin{array}{l}50 \% \text { of earning } 3.85 \text { euros } \\
50 \% \text { of earning } 0.1 \text { euros }\end{array}$ & - Option A & - Option B \\
\hline 6 & $\begin{array}{l}60 \% \text { of earning } 2.0 \text { euros } \\
40 \% \text { of earning } 1.6 \text { euros }\end{array}$ & $\begin{array}{l}60 \% \text { of earning } 3.85 \text { euros } \\
40 \% \text { of earning } 0.1 \text { euros }\end{array}$ & - Option A & - Option B \\
\hline 7 & $\begin{array}{l}70 \% \text { of earning } 2.0 \text { euros } \\
30 \% \text { of earning } 1.6 \text { euros }\end{array}$ & $\begin{array}{l}70 \% \text { of earning } 3.85 \text { euros } \\
30 \% \text { of earning } 0.1 \text { euros }\end{array}$ & - Option A & - Option B \\
\hline 8 & $\begin{array}{l}80 \% \text { of earning } 2.0 \text { euros } \\
20 \% \text { of earning } 1.6 \text { euros }\end{array}$ & $\begin{array}{l}80 \% \text { of earning } 3.85 \text { euros } \\
20 \% \text { of earning } 0.1 \text { euros }\end{array}$ & - Option A & - Option B \\
\hline 9 & $\begin{array}{l}90 \% \text { of earning } 2.0 \text { euros } \\
10 \% \text { of earning } 1.6 \text { euros }\end{array}$ & $\begin{array}{l}90 \% \text { of earning } 3.85 \text { euros } \\
10 \% \text { of earning } 0.1 \text { euros }\end{array}$ & - Option A & - Option B \\
\hline 10 & $\begin{array}{l}100 \% \text { of earning } 2.0 \text { euros } \\
0 \% \text { of earning } 1.6 \text { euros }\end{array}$ & $\begin{array}{l}100 \% \text { of earning } 3.85 \text { euros } \\
0 \% \text { of earning } 0.1 \text { euros }\end{array}$ & - Option A & - Option B \\
\hline
\end{tabular}

This test was incentivized. The average earning is 2.4 euros (minimum earning: 0.1 euro; maximum earning: 3.85 euros). 
Table I.2: Distribution of the number of safe choices (option A) in the Holt and Laury task

\begin{tabular}{|c|c|c|c|c|c|c|c|c|c|c|c|c|c|}
\hline $\begin{array}{l}\text { Number } \\
\text { of safe } \\
\text { choices }\end{array}$ & 0 & 1 & 2 & 3 & 4 & 5 & 6 & 7 & 8 & 9 & 10 & Mean & $\begin{array}{l}\text { Standard } \\
\text { devia- } \\
\text { tion }\end{array}$ \\
\hline $\begin{array}{l}\% \text { of } \\
\text { partici- } \\
\text { pants }\end{array}$ & 0 & 0 & 0 & 4.65 & 19.77 & 17.44 & 18.60 & 20.93 & 11.63 & 4.65 & 2.33 & 5.96 & 1.69 \\
\hline
\end{tabular}

\section{Block 3}

\section{Personality test}

Basic information and materials for the HEXACO Personality Inventory-Revised (Ashton and Lee, 2009), a test that assesses the six major dimensions of personality (Honesty-Humility, Emotionality, eXtraversion, Agreeableness (versus Anger), Conscientiousness, Openness to Experience) is made available by Kibeom Lee and Michael C. Ashton at http://hexaco.org/hexaco-inventory. We used the following 60-item version of the test. For each statement, participants answered using a 5-level Likert scale from strongly disagree (1) to strongly agree (5).

1 I would be quite bored by a visit to an art gallery.

2 I plan ahead and organize things, to avoid scrambling at the last minute.

3 I rarely hold a grudge, even against people who have badly wronged me.

4 I feel reasonably satisfied with myself overall.

5 I would feel afraid if I had to travel in bad weather conditions.

6 I wouldn't use flattery to get a raise or promotion at work, even if I thought it would succeed.

7 I'm interested in learning about the history and politics of other countries.

8 I often push myself very hard when trying to achieve a goal.

9 People sometimes tell me that I am too critical of others.

10 I rarely express my opinions in group meetings.

11 I sometimes can't help worrying about little things.

12 If I knew that I could never get caught, I would be willing to steal a million dollars.

13 I would enjoy creating a work of art, such as a novel, a song, or a painting.

14 When working on something, I don't pay much attention to small details.

15 People sometimes tell me that I'm too stubborn.

16 I prefer jobs that involve active social interaction to those that involve working alone.

17 When I suffer from a painful experience, I need someone to make me feel comfortable. 
18 Having a lot of money is not especially important to me.

19 I think that paying attention to radical ideas is a waste of time.

20 I make decisions based on the feeling of the moment rather than on careful thought.

21 People think of me as someone who has a quick temper.

22 On most days, I feel cheerful and optimistic.

23 I feel like crying when I see other people crying.

24 I think that I am entitled to more respect than the average person is.

25 If I had the opportunity, I would like to attend a classical music concert.

26 When working, I sometimes have difficulties due to being disorganized.

27 My attitude toward people who have treated me badly is "forgive and forget".

28 I feel that I am an unpopular person.

29 When it comes to physical danger, I am very fearful.

30 If I want something from someone, I will laugh at that person's worst jokes.

31 I've never really enjoyed looking through an encyclopedia.

32 I do only the minimum amount of work needed to get by.

33 I tend to be lenient in judging other people.

34 In social situations, I'm usually the one who makes the first move.

35 I worry a lot less than most people do.

36 I would never accept a bribe, even if it were very large.

37 People have often told me that I have a good imagination.

38 I always try to be accurate in my work, even at the expense of time.

39 I am usually quite flexible in my opinions when people disagree with me.

40 The first thing that I always do in a new place is to make friends.

41 I can handle difficult situations without needing emotional support from anyone else.

42 I would get a lot of pleasure from owning expensive luxury goods.

43 I like people who have unconventional views.

44 I make a lot of mistakes because I don't think before I act. 
45 Most people tend to get angry more quickly than I do.

46 Most people are more upbeat and dynamic than I generally am.

47 I feel strong emotions when someone close to me is going away for a long time.

48 I want people to know that I am an important person of high status.

49 I don't think of myself as the artistic or creative type.

50 People often call me a perfectionist.

51 Even when people make a lot of mistakes, I rarely say anything negative.

52 I sometimes feel that I am a worthless person.

53 Even in an emergency I wouldn't feel like panicking.

54 I wouldn't pretend to like someone just to get that person to do favors for me.

55 I find it boring to discuss philosophy.

56 I prefer to do whatever comes to mind, rather than stick to a plan.

57 When people tell me that I'm wrong, my first reaction is to argue with them.

58 When I'm in a group of people, I'm often the one who speaks on behalf of the group.

59 I remain unemotional even in situations where most people get very sentimental.

60 I'd be tempted to use counterfeit money, if I were sure I could get away with it.

This test was not incentivized and yielded no earnings. 
Table I.3: Descriptive statistics and Cronbach- $\alpha$ for the personality traits

\begin{tabular}{|l|l|l|l|l|}
\hline Personality trait & $\alpha$ & Mean & $\begin{array}{l}\text { Standard } \\
\text { deviation }\end{array}$ & Median \\
\hline HONESTY-HUMILITY & 0.79 & 33.55 & 7.34 & 33 \\
\hline EMOTIONALITY & 0.80 & 32.22 & 7.22 & 33 \\
\hline EXTRAVERSION & 0.79 & 35.68 & 6.06 & 36 \\
\hline AGREEABLENESS & 0.73 & 30.87 & 6.03 & 31 \\
\hline CONSCIENTIOUSNESS & 0.81 & 36.28 & 6.40 & 36 \\
\hline $\begin{array}{l}\text { OPENNESS TO EXPE- } \\
\text { RIENCE }\end{array}$ & 0.67 & 36.14 & 5.62 & 36 \\
\hline Fear & 0.59 & 8.76 & 2.72 & 8 \\
\hline Liveliness (hopefulness) & 0.68 & 7.53 & 1.60 & 8 \\
\hline Anger & 0.86 & 5.15 & 5.42 & 5 \\
\hline
\end{tabular}

HONESTY-HUMILITY score is defined as the sum of answers to questions: 6, 30R, 54, 12R, 36, 60R, 18, $42 \mathrm{R}, 24 \mathrm{R}, 48 \mathrm{R}$, where $\mathrm{R}$ stands for reversed item (which is scored as: 6-personality test score); EMOTIONALITY score is defined as the sum of answers to questions: 5, 29, 53R, 11, 35R, 17, 41R, 23, 47, 59R; EXTRAVERSION score as the sum of answers to questions: 4, 28R, 52R, 10R, 34, 58, 16, 40, 22, 46R; AGREEABLENESS score as the sum of answers to questions: 3, 27, 9R, 33, 51, 15R, 39, 57R, 21R, 45; CONSCIENTIOUSNESS as the sum of answers to questions: 2, 26R, 8, 32R, 14R, 38, 50, 20R, 44R, 56R; OPENNESS TO EXPERIENCE as the sum of answers to questions: 1R, 25, 7, 31R, 13, 37, 49R, 19R, 43, 55R; fear as the sum of answers to questions: 5, 29, 53R; liveliness as the sum of answers to: $22,46 \mathrm{R}$, and anger as the sum of answers to questions: $21,45 \mathrm{R}$.

\section{Block 4}

\section{Ambiguity aversion}

This test is based on Dimmock et al., (2016). The instructions are given here for a 2-color ambiguity aversion test; we conducted two other similar tests for 10 colors and 100 colors.

In this game, you can choose between Box I and Box C, both containing 100 balls, which can be either yellow or purple. One ball will be taken from the box you have chosen. You will earn 1 euro if a purple ball is picked.

For Box C, you can select the exact percentage of purple balls (p) and yellow balls (1-p) it contains. This percentage between 0 and $100 \%$ (p) must be chosen so that you are indifferent to picking a ball from Box I or picking a ball from Box C.

Box I also contains yellow and purple balls, but the percentages of balls of the two colors are not known in advance.

All in all, the two boxes contain 100 balls of two different colors (yellow and purple). However, the percentage of yellow and purple balls for Box C (Known) is chosen by yourself in advance, whereas this percentage is unknown and will remain unknown for Box I (Unknown). 
Box I

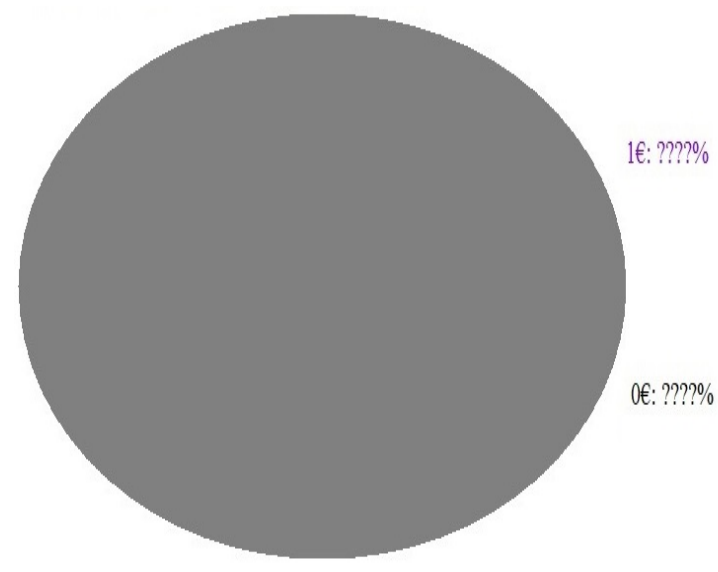

Box C

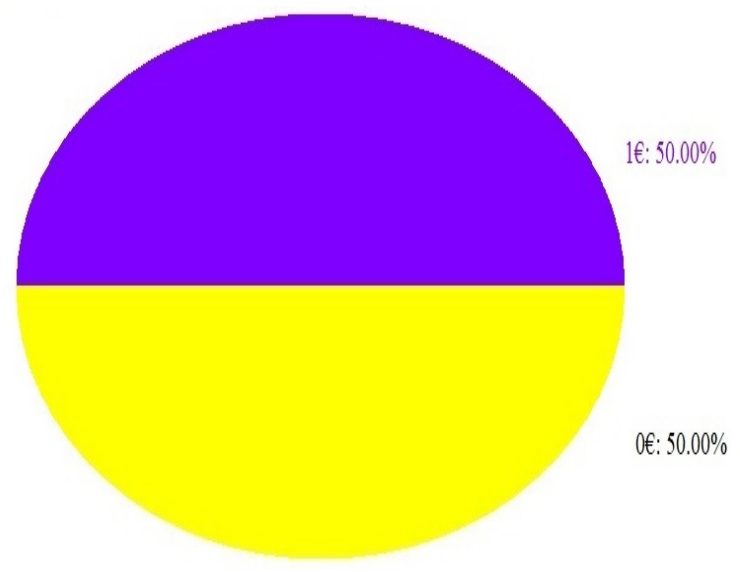

Your decision is to choose the percentage of purple balls in Box C (p) so that you are indifferent between picking a ball from Box I and picking a ball from Box C.

In this game, the computer will randomly choose a percentage between 1 and 100 (called $r$ ) to calculate your payoffs. Each integer between 1 and 100 has the same chance of being selected so that each number has a 1 in 100 chances of being selected.

- If the randomly selected percentage $(r)$ is less than the percentage of purple balls ( $p$ ) you chose for Box $\mathrm{C}$ then a ball will be drawn from Box I to calculate your payoffs.

- If the randomly selected percentage $(\mathrm{r})$ is greater than or equal to the percentage of purple balls $(\mathrm{p})$ you selected for Box $C$ then one ball will be drawn from Box $C$ to calculate your payoffs.

You will earn 1 euro if a purple ball is drawn and 0 euro if another color is drawn.

Choose the percentage of purple balls in Box C (p) so that you are indifferent between picking a ball from Box I and picking a ball from Box C:

\section{CONFIRM?}

A pop-up opens if participants do not try several values.

This test was incentivized. The average earning is 0.84 euro (minimum earning: 0 euro; maximum earning: 3 euros).

Table I.4: Distribution of scores in the ambiguity aversion test

\begin{tabular}{|c|c|c|c|c|c|c|c|c|c|c|c|c|}
\hline $\begin{array}{l}\text { Percentage } \\
\text { choice }\end{array}$ & {$[0,10($} & {$[10,20($} & {$[20,30($} & {$[30,40$ ( } & {$[40,50($} & {$[50,60($} & {$[60,70($} & {$[70,80($} & {$[80,90($} & {$[90,100]$} & Mean & $\begin{array}{l}\text { Standard } \\
\text { devia- } \\
\text { tion }\end{array}$ \\
\hline $\begin{array}{l}\% \text { of partic- } \\
\text { ipants }\end{array}$ & 0 & 3.49 & 12.79 & 13.95 & 15.11 & 33.72 & 10.46 & 4.65 & 4.65 & 1.16 & 48.11 & 17.21 \\
\hline
\end{tabular}

The ambiguity aversion test score is the average of a participant's chosen values across the three versions of the test. That is the 2-color version described above along with the 10- and 100-color versions. 


\section{Block 5}

\section{Estimation of tokens}

In order to have an idea about the participants' prior belief on the distribution of tokens, we asked them to estimate the proportion of an orange and a yellow token.

Estimation of orange tokens

On the following screen, you will see a photograph with tokens of several colors. We ask you to estimate the percentage of orange tokens. Enter a percentage with one decimal (ex: 5.0\% or $4.2 \%$ ). If your answer is correct (up to $0.1 \%$ ), you will receive $50 \notin$. You will have 15 seconds to answer. Click on the OK button once ready.

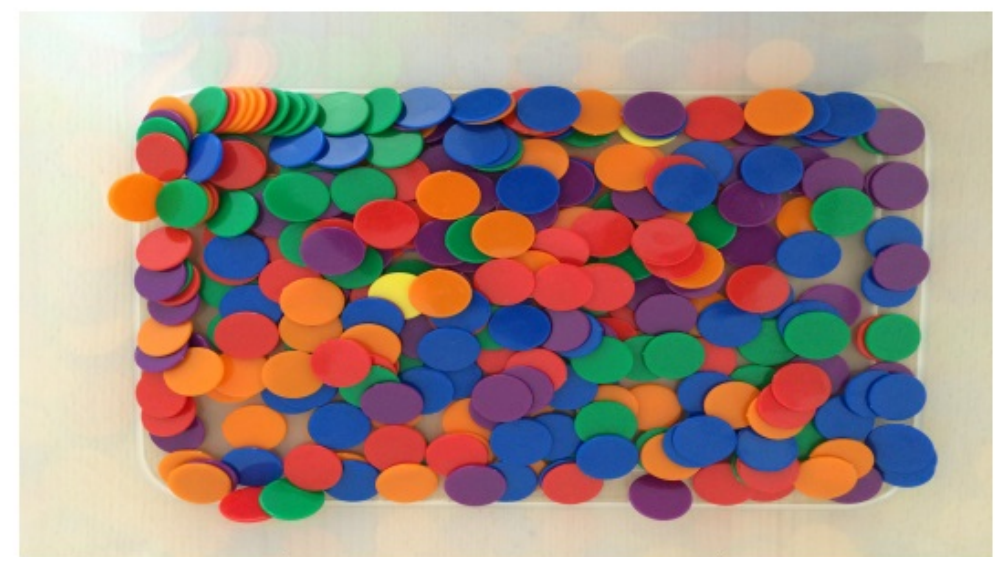

Your estimation of orange tokens:

Table I.5: Distribution of estimations for the orange token:

\begin{tabular}{|l|l|l|l|l|l|l|l|l|}
\hline $\begin{array}{l}\text { Estimation of or- } \\
\text { ange tokens }\end{array}$ & {$[0,10($} & {$[10,20($} & {$[20,30($} & {$[30,40($} & {$[40,50($} & $\geq 50$ & Mean & $\begin{array}{l}\text { Standard } \\
\text { deviation }\end{array}$ \\
\hline$\%$ of participants & 21,05 & 23,68 & 31,58 & 17,11 & 3,95 & 2,63 & 18.87 & 11.74 \\
\hline
\end{tabular}

\section{Estimation of yellow tokens}

On the following screen, you will see a photograph with tokens of several colors. We ask you to estimate the percentage of yellow tokens. Enter a percentage with one decimal (ex: 5.0\% or 4.2\%). If your answer is correct (up to $0.1 \%$ ), you will receive $50 \nless$. You will have 15 seconds to answer. Click on the OK button once ready. 


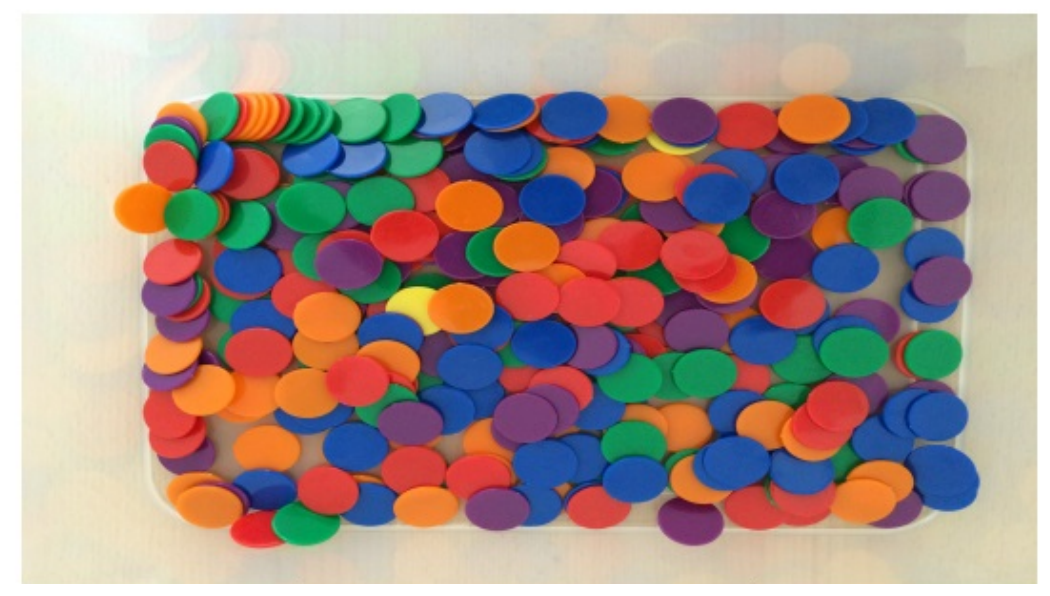

Your estimation of yellow tokens:

Table I.6: Distribution of estimations for the yellow token:

\begin{tabular}{|l|l|l|l|l|l|l|l|}
\hline $\begin{array}{l}\text { Estimation of yel- } \\
\text { low token (\%) }\end{array}$ & {$[0,1($} & {$[1,2($} & {$[2,3($} & {$[3,10($} & $\geq 10$ & Mean & $\begin{array}{l}\text { Standard } \\
\text { devia- } \\
\text { tion }\end{array}$ \\
\hline \% of participants & 36.90 & 26.19 & 14.28 & 9.52 & 25 & 6.16 & 9.41 \\
\hline
\end{tabular}

This two-estimation test was incentivized. The average earning is 0.09 euro (minimum earning: 0 euro; maximum earning: 0.5 euro). Note that the photograph used for the test is the same as the one shown on participants' screen in Day 2.

\section{Block 6}

\section{Extended Cognitive Reflection Test (CRT)}

We administered the extended (seven-question) version of the CRT in which the original three questions (Frederick, 2005) are augmented with four additional questions developed and validated by Toplak, West and Stanovich (2014). Our measure of cognitive reflection is given by the total number of correct answers (from 0 to 7). Participants had 5 minutes in total to complete the CRT.

Taken from Frederick (2005):

1 A bat and a ball cost $\$ 1.10$ in total. The bat costs a dollar more than the ball. How much does the ball cost? _-_- cents [Correct answer: 5 cents; intuitive answer: 10 cents]

2 If it takes 5 machines 5 minutes to make 5 widgets, how long would it take 100 machines to make 100 widgets? _-_- minutes [Correct answer: 5 minutes; intuitive answer: 100 minutes]

3 In a lake, there is a patch of lily pads. Every day, the patch doubles in size. If it takes 48 days for the patch to cover the entire lake, how long would it take for the patch to cover half of the lake? _-_-_ days [Correct answer: 47 days; intuitive answer: 24 days]

Taken from Toplak et al., (2014): 
4 If John can drink one barrel of water in 6 days, and Mary can drink one barrel of water in 12 days, how long would it take them to drink one barrel of water together? _-_-_ days [correct answer: 4 days; intuitive answer: 9]

5 Jerry received both the 15th highest and the 15th lowest mark in the class. How many students are in the class? --_--- students [correct answer: 29 students; intuitive answer: 30 ]

6 A man buys a pig for $\$ 60$, sells it for $\$ 70$, buys it back for $\$ 80$, and sells it finally for $\$ 90$. How much has he made? _-_-_ dollars [correct answer: \$20; intuitive answer: \$10]

7 Simon decided to invest $\$ 8,000$ in the stock market one day early in 2008 . Six months after he invested, on July 17, the stocks he had purchased were down 50\%. Fortunately for Simon, from July 17 to October 17, the stocks he had purchased went up 75\%. At this point, Simon has: a. broken even in the stock market, b. is ahead of where he began, c. has lost money [correct answer: c; intuitive response: b]

This test was not incentivized and yielded no earnings.

Table I.7: Distribution of CRT scores

\begin{tabular}{|c|c|c|c|c|c|c|c|c|c|c|}
\hline CRT scores & 0 & 1 & 2 & 3 & 4 & 5 & 6 & 7 & Mean & Std. Dev. \\
\hline \% of participants & 2.33 & 10.46 & 5.81 & 10.47 & 12.79 & 20.93 & 18.6 & 18.6 & 4.51 & 2.00 \\
\hline
\end{tabular}

The CRT score corresponds to the number of correct answers to the seven questions.

\section{Block 7 \\ Availability heuristic 1}

Based on Tversky and Kahneman (1974), we asked the 5 following questions (answers were computed using the following website in French: https://www.listesdemots.net), for which participants had 25 seconds to answer. This test intended to measure the availability bias of participants, that is whether participants make judgments about the likelihood of an event based on how easily an example, instance, or case comes to mind.

In a French language dictionary:

1 Are there more words where the letter I appears first or third?

What is your estimate of the ratio of words where the letter I appears first to words where the letter I appears third (a ratio of 1 means that there are as many words where the letter I appears first and where the letter I appears first or third): _-- [true ratio: 0.59]

2 Are there more words where the letter L appears in fourth or first position?

What is your estimate of the ratio of words where the letter L appears in fourth position to words where the letter L appears in first position? [true ratio: 2.37] 
3 Are there more words where the letter P appears in second or fifth position?

What is your estimate of the ratio of words where the letter $\mathrm{P}$ appears second to words where the letter $\mathrm{P}$ appears fifth? [true ratio: 0.84 ]

4 Are there more words where the letter $\mathrm{N}$ appears first or fifth?

What is your estimate of the ratio of words where the letter $\mathrm{N}$ appears first compared to words where the letter $\mathrm{N}$ appears fifth: _-_ [true ratio: 0.18 ]

5 Are there more words where the letter D appears last or sixth?

What is your estimate of the ratio of words where the letter D appears last compared to words where the letter D appears sixth: _-- [true ratio: 0.07]

This test was not incentivized and yielded no earnings.

Table I.8: Distribution of availability scores

\begin{tabular}{|c|c|c|c|c|c|c|c|c|}
\hline Availability heuristic scores & 0 & 1 & 2 & 3 & 4 & 5 & Mean & Std. Dev. \\
\hline \% of participants & 5.81 & 25.58 & 32.56 & 29.07 & 6.98 & 0 & 2.06 & 1.03 \\
\hline
\end{tabular}

The score corresponds to the number of correct answers to the first question of each of the 5 groups of 2 questions.

\section{Block 8}

\section{Loss aversion}

Following Brink and Rankin (2013) we use the following loss aversion test.

For this task, your potential losses will be subtracted from your total gains in the various tests.

For each line in the table on the following screen: please indicate whether you prefer option A or option B. Even if the table has a total of 10 rows, only one row will be randomly selected for the calculation of your gains or losses. Since all lines are likely to be selected for the calculation of your gains or losses, you must give equal weight to each of your decisions. At the end of the experiment, a number between 1 and 10 will be randomly selected by the computer. This number will determine which line will be used to calculate your gains or losses. The computer will randomly select a second number between 1 and 6 to determine the exact amount of your gains or losses.

Example:

You have chosen one option (A or B) for each of the ten rows in the table. Next, the computer randomly selects row 7 to be used to calculate your gains and losses.

- If you selected option A for line 7, then you will lose 2.40 euros if the second number chosen by the computer at random is 1,2 or 3 . If the second number chosen by the computer is 4,5 or 6 you will win 5.00 euros.

- If you selected option B for line 7, then you will lose 1.00 euro if the second number chosen by the computer at random is 1,2 or 3 . If the second number chosen by the computer is 4,5 or 6 you will win 1.00 euro. 


\begin{tabular}{|c|c|c|c|c|}
\hline Decision & Option A & Option B & \multicolumn{2}{|c|}{ Option choice } \\
\hline 1 & $\begin{array}{l}50 \% \text { of losing } 1.4 \text { euro(s) } \\
50 \% \text { of winning } 5 \text { euro(s) }\end{array}$ & $\begin{array}{l}50 \% \text { of losing } 1 \text { euro } \\
50 \% \text { of winning } 1 \text { euro }\end{array}$ & - Option A & - Option B \\
\hline 2 & $\begin{array}{l}50 \% \text { of losing } 1.5 \text { euro(s) } \\
50 \% \text { of winning } 5 \text { euro(s) }\end{array}$ & $\begin{array}{l}50 \% \text { of losing } 1 \text { euro } \\
50 \% \text { of winning } 1 \text { euro }\end{array}$ & - Option A & - Option B \\
\hline 3 & $\begin{array}{l}50 \% \text { of losing } 1.6 \text { euro(s) } \\
50 \% \text { of winning } 5 \text { euro(s) }\end{array}$ & $\begin{array}{l}50 \% \text { of losing } 1 \text { euro } \\
50 \% \text { of winning } 1 \text { euro }\end{array}$ & - Option A & - Option B \\
\hline 4 & $\begin{array}{l}50 \% \text { of losing } 1.75 \text { euro(s) } \\
50 \% \text { of winning } 5 \text { euro(s) }\end{array}$ & $\begin{array}{l}50 \% \text { of losing } 1 \text { euro } \\
50 \% \text { of winning } 1 \text { euro }\end{array}$ & - Option A & - Option B \\
\hline 5 & $\begin{array}{l}50 \% \text { of losing } 1.9 \text { euro(s) } \\
50 \% \text { of winning } 5 \text { euro(s) }\end{array}$ & $\begin{array}{l}50 \% \text { of losing } 1 \text { euro } \\
50 \% \text { of winning } 1 \text { euro }\end{array}$ & - Option A & - Option B \\
\hline 6 & $\begin{array}{l}50 \% \text { of losing } 2.1 \text { euro(s) } \\
50 \% \text { of winning } 5 \text { euro(s) }\end{array}$ & $\begin{array}{l}50 \% \text { of losing } 1 \text { euro } \\
50 \% \text { of winning } 1 \text { euro }\end{array}$ & - Option A & - Option B \\
\hline 7 & $\begin{array}{l}50 \% \text { of losing } 2.4 \text { euro(s) } \\
50 \% \text { of winning } 5 \text { euro(s) }\end{array}$ & $\begin{array}{l}50 \% \text { of losing } 1 \text { euro } \\
50 \% \text { of winning } 1 \text { euro }\end{array}$ & - Option A & - Option B \\
\hline 8 & $\begin{array}{l}50 \% \text { of losing } 2.9 \text { euro(s) } \\
50 \% \text { of winning } 5 \text { euro(s) }\end{array}$ & $\begin{array}{l}50 \% \text { of losing } 1 \text { euro } \\
50 \% \text { of winning } 1 \text { euro }\end{array}$ & - Option A & - Option B \\
\hline 9 & $\begin{array}{l}50 \% \text { of losing } 3.95 \text { euro(s) } \\
50 \% \text { of winning } 5 \text { euro(s) }\end{array}$ & $\begin{array}{l}50 \% \text { of losing } 1 \text { euro } \\
50 \% \text { of winning } 1 \text { euro }\end{array}$ & - Option A & - Option B \\
\hline 10 & $\begin{array}{l}50 \% \text { of losing } 7 \text { euro(s) } \\
50 \% \text { of winning } 5 \text { euro(s) }\end{array}$ & $\begin{array}{l}50 \% \text { of losing } 1 \text { euro } \\
50 \% \text { of winning } 1 \text { euro }\end{array}$ & - Option A & - Option B \\
\hline
\end{tabular}

This test was incentivized. The average earning is 0.82 euro (minimum earning: -7 euros; maximum earning: 5 euros).

Distribution of option A choices in the loss aversion task

\begin{tabular}{|l|l|l|l|l|l|l|l|l|l|l|l|l|l|}
\hline $\begin{array}{l}\text { No. of } \\
\text { option A }\end{array}$ & 0 & 1 & 2 & 3 & 4 & 5 & 6 & 7 & 8 & 9 & 10 & Mean & $\begin{array}{l}\text { Std. } \\
\text { Dev. }\end{array}$ \\
\hline $\begin{array}{l}\text { \% of par- } \\
\text { ticipants }\end{array}$ & 1.16 & 2.33 & 4.65 & 2.33 & 6.98 & 24.42 & 20.93 & 15.12 & 10.45 & 4.65 & 6.98 & 5.95 & 2.14 \\
\hline
\end{tabular}

\section{Block 9}

\section{Reactance scale}

Following Hong and Faedda (1996), we asked participants to evaluate on a scale from 1 to 5 ( 1 = Strongly agree, 2 = Agree, 3 = Neither agree nor disagree, $4=$ Disagree, $5=$ Strongly disagree), the extent to which they agree or disagree with the following 11 statements ${ }^{38}$ :

1. Regulations trigger a sense of resistance in me.

2. I find contradicting others stimulating.

\footnotetext{
${ }^{38}$ We selected the 11 -item version of the test for its psychometric properties.
} 
3. When something is prohibited, I usually think that's exactly what I am going to do.

4. I consider advice from others to be an intrusion.

5. I become frustrated when I am unable to make free and independent decisions.

6. It irritates me when someone points out things which are obvious to me.

7. I become angry when my freedom of choice is restricted.

8. Advice and recommendations induce me to do just the opposite.

9. I resist the attempts of others to influence me.

10. It makes me angry when another person is held up as a model to follow.

11. When someone forces me to do something, I feel like doing the opposite.

This test was not incentivized and yielded no earnings.

Table I.9: Distribution of reactance score

\begin{tabular}{|l|l|l|l|l|l|l|l|}
\hline $\begin{array}{l}\text { Reactance } \\
\text { score }\end{array}$ & {$[0,10($} & {$[10,20($} & {$[20,30($} & {$[30,40($} & {$[40,50]$} & Mean & $\begin{array}{l}\text { Standard } \\
\text { deviation }\end{array}$ \\
\hline $\begin{array}{l}\% \text { of partici- } \\
\text { pants }\end{array}$ & 0 & 1.16 & 22.09 & 67.44 & 9.30 & 33.14 & 5.21 \\
\hline
\end{tabular}

The score is computed by summing the evaluations over the 11 statements.

Block 10

Availability heuristic 2

Based on Tversky and Kahneman (1974), we administered a second availability heuristic test.

We are going to show you a list of names. Please click OK to view this list. Please pay attention.

Mark WRIGHT, Jessica JAMES, Angelina JOLIE, Harry ROBINSON, Steve JOBS, Brandon HUGHES, John CLARKE, Sophie LEWIS, Albert EINSTEIN, Thomas PALMAN, Michelle GARRETT, Joseph SCOTT, Vincent VAN GOGH, Jack BROWN, David CLARKE, Emily ROBERTS, Marie CURIE, Roselyn LACHMAN, Janett SMITH, Julie EVANS, Nelson MANDELA, Oliver JOHNSON, Martin MORTON, Kylie DAVIES, Audrey HEPBURN, Justin TAYLOR, George WILSON, Andrew ROBINSON, Marilyn MONROE, Christine COOPER, Anne EDWARDS, Susan WOOD, Coco CHANNEL, Emma HILL, Ellen MOORE, Dylan MILLER, Michael JACKSON, Peter HALL, Alice WARD, Patricia GREEN.

Were the following names on the list? You will have 4 seconds to answer for each name. Please click OK to view the list of names. 
Harry ROBINSON, Marie CURIE, Jack BROWN, Holly WILKINSON, Edit PIAF, Charles HUNT, Coco CHANNEL, Brandon HUGHES, Elvis PRESLEY, Albert EINSTEIN, Justin TAYLOR, Pablo PICASSO, Nelson MANDELA, Nancy PALMER, Vincent VAN GOGH, Emily ROBERTS, Bill GATES, Christopher LLOYD, Britney SPEARS, Dennis ELLISON.

This test was not incentivized and yielded no earnings.

Table I.10: Distribution of scores in the availability heuristic 2 test

\begin{tabular}{|l|l|l|l|l|l|l|l|l|}
\hline $\begin{array}{l}\text { Availability } \\
\text { heuristic } \\
\text { scores }\end{array}$ & $<0.3$ & {$[0.3,0.4($} & {$[0.4,0.5($} & {$[0.5,0.6($} & {$[0.6,0.7($} & $>0.7$ & Mean & Std. Dev. \\
\hline $\begin{array}{l}\% \text { of partici- } \\
\text { pants }\end{array}$ & 0 & 1.2 & 24.4 & 62.8 & 11.6 & 0 & 0.52 & 0.003 \\
\hline
\end{tabular}

The score is computed as the ratio of correct answers involving famous names to the total of correct answers.

\section{Block 11}

Eyes gaze test

Following Bruguier et al., (2010) and De Martino et al., (2013), we administered the Theory of Mind (ToM) test (Baron-Cohen et al., 1997) to assess participants' theory of mind skills. In this task, participants looked at images of people's eyes and had to choose one of four feelings that best described the mental state of the person whose eyes were shown. Our ToM score is defined as the number of correct answers to the 36-question test.

Here is an example of one of the 36 questions in the test of Baron-Cohen (1997):

jealous panicked

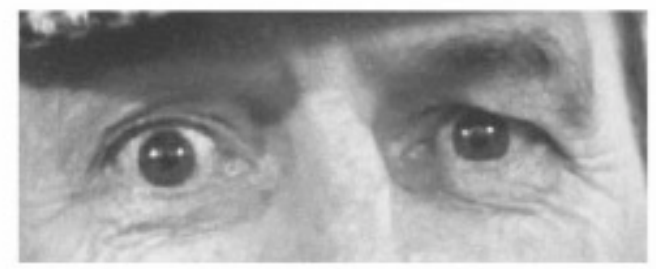

arrogant

hateful

This test was not incentivized and yielded no earnings.

This test was performed only for reasons of comparability with other treatments involving markets and which are not studied in this paper. We do not make use of the results of this test since it is not relevant for the purpose of the paper. We do not report descriptive statistics for this test. 


\section{Block 12}

\section{Demographic data}

We asked participants about a few demographic questions: age, gender, diploma, grades, socio-professional category, color blindness, number of previous participation in experimental sessions, mother tongue.

We thank you for participating in this first session and look forward to seeing you on the SCHEDULE DATE for the second session. We compensate you for your participation. However, you will receive the payoffs related to the tests at the end of the second experimental session. If you do not come to the second session, these payoffs will be permanently lost.

\section{I.2 SPECIFIC PROTOCOL FOR DAY 2 SESSIONS (oral instructions)}

Once all participants have sat randomly in front of a computer, the experimenter tells them the following.

Welcome. Thank you for participating in this experiment.

Please turn off your phone. You cannot use your phone during this experiment. Paper and pencils are also forbidden. Do not talk to other participants throughout the session.

If at any time during the session you need help, raise your hand and we will immediately come to answer your questions in private. You are 7 people participating in this experiment. Among the 7 participants, one of you was randomly selected to perform a different task from the other 6 participants. This task consists in drawing tokens from the box. This participant will not know the task that the other 6 participants will perform during this experiment. We will now show you the box containing tokens. Look at the box. As you can see, this box contains tokens of 6 different colors.

After the experimenter has shown the box, he tells the participants: We will take a picture that will be reported on your screen to remind you the contents of the box.

The experimenter takes a photograph that is supposed to resemble the one depicted on participants' screens later on.

Once the selected participant goes into the control room, with the box and bag, the experimenter asks him or her: Do you distinguish the 6 colors well?

The selected participant starts the task under the supervision of the experimenter.

For the remaining six participants, the experimenter tells them: This experiment requires the use of a physiological measurement tool. The experimenter will come to each of you to install it on the hand that you don't usually use to write. The experiment will begin when all participants are equipped and we have ensured that the recordings are good.

The experimenter asks participants to rub their hands and installs the physiological tool on the second phalanx of the index and middle fingers of one's participant's hand by applying isotonic gel on the electrodes.

\section{I.3 SPECIFIC INSTRUCTIONS FOR PARTICIPANTS IN DAY 2 SESSIONS (on screen)}

\section{General presentation at the arrival of the second session}

Today is the second experimental session. 
You are 7 people participating in this experiment. Among the 7 participants, one of you has been randomly chosen to perform a different task from the other 6 participants. This participant does not know the task that the other 6 participants will perform during this experiment.

\section{I.3.1 Specific instructions for the randomly selected participant}

You are the selected participant. You have been selected to perform a different task from the other 6 participants.

Your task is to:

- put all the chips in an opaque bag;

- pick a token from the bag, tick the color of the token on your computer screen, tick the color of the token on the sheet of paper in front of you, put the token back into the opaque bag (so that the contents of the bag always remains the same), mix the tokens, and again pick a token from the bag, tick the color of the token on your computer screen, tick the color of the token on the sheet of paper, put the token back in the bag, mix the tokens, and so on until you have drawn a total of 300 tokens;

- to sign the sheet of paper at the end of your task.

Your earnings consist of a fixed amount of 15 euros. If you do not complete your task in an hour, or if you make a mistake (i.e., tick the wrong color), you will only be paid 10 euros. You will be under the supervision of an experimenter at all times.

It is expected that you will take an average of 10 seconds to pull a token, tick the color of the token on your computer, tick the color on the sheet of paper, mix the tokens. A timer on the computer will tell you if you are on time.

\section{I.3.2 Specific instructions for the other participants}

You are not the participant selected to draw the tokens.

The task of the randomly selected participant is:

- to put all the tokens in an opaque bag;

- to pick a token from the bag, tick the color of the token on the computer screen, tick the color of the token on a sheet of paper, put the token back into the opaque bag (so that the content of the bag always remains the same), mix the tokens, and again pick a token from the bag, tick the color of the token on the computer screen, tick the color of the token on the sheet of paper, put the token back in the bag, mix the tokens, and so on until he or she draws 300 tokens in total;

- to sign the sheet of paper at the end of the task.

The participant selected to draw the tokens will be paid 15 euros for the task if he or she finishes on time, i.e., in one hour. A timer will be displayed on the screen to help this participant find the right pace.

\section{Your task:}

You will play for 300 periods.

Each period, your task is to decide how much you are willing to pay for a lottery that gives you the following payoffs (which may be negative) depending on the color of the token drawn by the randomly selected participant: 
- Blue: 10 cents

- Red: 20 cents

- Orange: 30 cents

- Green: 40 cents

- Purple: 50 cents

- Yellow: -1000 cents

The outcome of the lottery in one period is independent of the outcome of the lottery in another period: in each period a new token is drawn into the bag which has strictly the same content in each period. Remember that the randomly selected participant who draws the tokens must pick the token from the bag, tick the color of the token on the computer, tick the color on a sheet of paper, put the token back into the opaque bag, so that the content of the bag always remains the same, mix the tokens, and again pull a token into the bag, tick the color of the token on the computer, tick the color on the sheet of paper, put the token back in the bag, mix the tokens and so on, until it does so for a total number of 300 tokens.

\section{Your task:}

To make your decisions, you will use the fixed amount of 12 euros (1200 cents) that you were attributed to answer the tests during the first experimental session.

This initial endowment is intended both to allow you to pay the lottery and to deal with the possibility of a yellow token being drawn. The earnings for each period are added to this initial endowment.

In addition, we make you a loan of 10 euros (1000 cents) for liquidity reasons, which you will repay at the end of the experiment.

If your endowment is no longer sufficient to cover the actual occurrence of a yellow token, you will no longer be able to participate in the experiment and you will only earn your variable payoffs acquired during the tests as well as 5 euros for showing-up.

You can select on your screen any price between 0 and 50 cents up to which you would be willing to buy the lottery.

The computer randomly selects an integer from 1 to 50 .

If the price you indicate is greater than or equal to the number selected by the computer, then you buy the lottery for the price equal to the number selected by the computer.

If the price you indicate is strictly lower than the number selected by the computer, then you keep your endowment and do not buy the lottery.

Each period, your payoff, if you actually buy the lottery, is given by:

Lottery payoff - price paid to purchase the lottery

Your total earnings over the 300 periods are given by:

1200 cents of fixed wage earned on Day $1+$ (lottery payoff - price you paid to buy the lottery) $\times 300$ periods + variable earnings on Day $1+5$ euros of show-up fee.

\section{Example 1}


You have entered a price of 28 at which you are ready to buy the lottery.

The computer randomly selects between 1 and 50 the number 12. In this case, the price you have indicated is higher than the selected number, so you buy the lottery for 12 cents that corresponds to the number selected by the computer. This lottery will give you:

- 10 cents if the token drawn is blue, in which case your payoff for this period is -2 cents (10-12).

- 20 cents if it is red, in which case your payoff for this period is 8 cents (20-12).

- 30 cents if it is orange, in which case your payoff for this period is 18 cents (30-12).

- 40 cents if it is green, in which case your payoff for this period is 28 cents (40-12).

- 50 cents if it is purple, in which case your payoff for this period is 38 cents (50-12).

- $-1,000$ cents if it is yellow, in which case your payoff for this period is -1012 cents $(-1000-12)$.

\section{Example 2}

You have entered a price of 21 and the computer randomly selects between 1 and 50 the number 43 .

In this case, the price you have indicated is lower than the selected number, so you will not buy the lottery.

In this case, your payoff is 0 for this period.

\section{Information:}

At the end of each period, you will be informed about the token that has been drawn, your payoff for the lottery, as well as your available cash which is equal to your initial endowment $(2200$ cents) plus or minus the accumulated gains and losses for buying (or not) the lottery.

You will also be able to see this information at the bottom of your screen for all periods before the current period.

At the end of the experiment, if you wish, you can have a look at the sheet of paper signed by the participant who drew the tokens. This will allow you to check that the sequence of drawn tokens is correct.

\section{Decision-making time:}

To ensure that the experiment is completed on time, we expect you to make your decision within 10 seconds in each period.

Note that you can take a little more time at the beginning of the experiment and that you are expected to make your decisions more quickly over time.

You are given 30 seconds in the first period and 20 seconds in the second period.

From the third period onwards, you will have 10 seconds to make your decision. A timer on the screen will indicate the time you have to enter a price using the cursor and validate your decision. If you do not enter a price on the screen and validate your decision in time, the number indicated by the cursor will be selected. 


\section{I.4 Example of a decision screen}

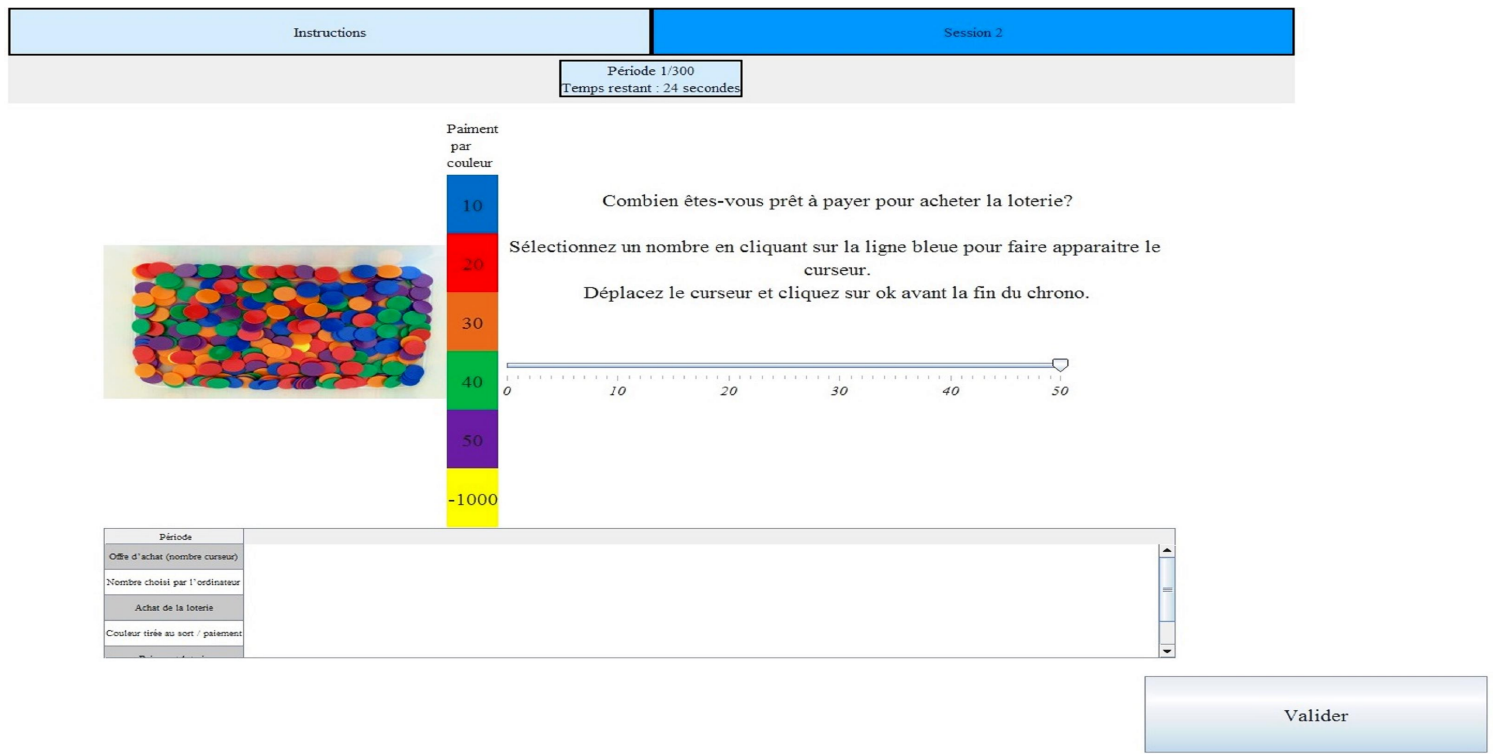

The software is available at: shorturl.at/rRZ04.

To see the task of Day 1: In the Config file write session=1; then launch Myopie.jar, once the first screen appears click on F6 (or Fn F6 from a laptop).

To see the picker's task of Day 2: In the Config file write session= 2 and type $=0$; then launch Myopie.jar, once the first screen appears click on F6 (or Fn F6 from a laptop).

To see the investor's task of Day 2: In the Config file write session= 2 and type $=1$; then launch Myopie.jar, once the first screen appears click on F6 (or Fn F6 from a laptop). 


\section{Simulations}

\section{II.1 Procedures}

To generate the simulated dynamics of bids before and after observing the tail event (Figures 1 and 2 in the main text, Figures II.1 and II.2 in this online appendix, as well as the figures in Online Appendix III), we use the payoff sequence 2 from our experiment in which 4 tail events occurred (see Figure A.1). We report the dynamics of bids around the first tail event in period 49 (the remaining three happen in periods 147, 179, and 257). The reason for choosing the first event is that simulated investors have not accumulated much wealth yet, so that suffering the tail event will put them in the loss domain (their wealth level will be below 1200). In addition, this is a case in which investors will not go bankrupt because they are facing the tail event for the first time. The random draw $\left(r_{t}\right)$ for the BDM mechanism also follows the realized sequence of the experimental sessions, except for period 49 . We set $r_{49}=1$ to simulate the case where the tail event is observed but not suffered, while $r_{49}=50$ for the case where the tail event is suffered.

By contrast, Figure 3 in the main text and Figure II. 3 in this online appendix are based on all the 15 realized payoff sequences from the experiment. For each sequence, we have then generated 100 random sequences of prices. Thus, for each of the possible sets of parameter values, we have run 1500 simulations. In each simulation, we kept track of average bids, of the number of tail events suffered and observed (before bankruptcy) as well as final wealth (in case of bankruptcy it is set to zero). For each number of tail events ( 0 , $1,2,3$, and 4) and set of parameter values, we take the average of these values across all these simulations to compute the average outcome. Figures 3 and II. 3 are based on computing averages across each possible number of tail events in the simulation and on each possible value of $\lambda^{i}$.

We have used the following set of parameter values: $\pi^{i} \in\{0.0025,0.005,0.0075,0.01,0.0125\} ; \eta^{i} \in$ $\{50,100,200,300\} ; \alpha^{i} \in\{0.25,0.5,0.75,1\} ; \lambda \in\{1.0,1.5,2.0,2.5\}, \rho^{i} \in\{0,0.25,0.5,0.75,1\} ; \omega^{i} \in\{0,0.25,0.5,0.75,1\} ;$ $\mu^{i} \in\{0.25,0.5,1,2,4\}$. Obviously, for the EUT framework, only $\eta^{i}, \pi^{i}, \alpha^{i}, \rho^{i}$, and $\mu^{i}$ are varied.

\section{II.2 Additional graphs}

(a) EUT

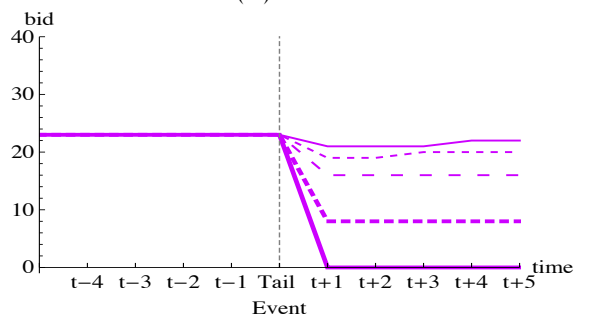

(b) PT

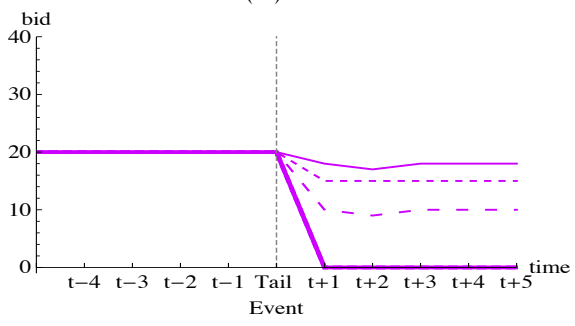

Note: In panel (b), the thick dashed line $(\mu=2)$ overlaps with the thick solid line $(\mu=4)$.

Figure II.1: Dynamics of bids around the tail event when it was not suffered for 5 values of $\mu, 0.25$ (thin solid), 0.5 (thin dashed), 1 (thin wide dashed), 2 (thick dashed) and 4 (thick solid) for (a) EUT ( $\alpha=0.75$ ) and (b) PT ( $\lambda=1.5$ and $\alpha=0.75)$. We assume no recency bias $(\rho=1)$ and $\omega=1.0$ 
(a) EUT

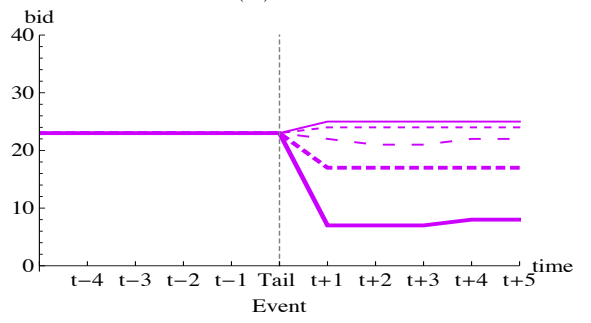

(b) PT

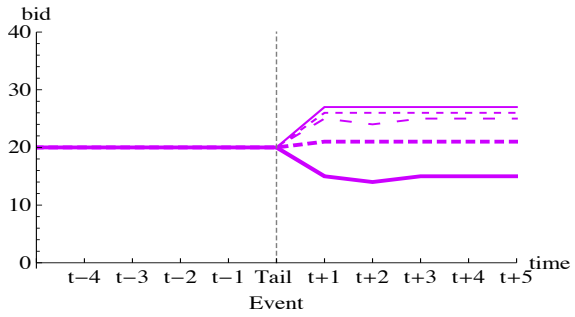

Figure II.2: Dynamics of bids around the tail event when it was suffered for 5 values of $\mu, 0.25$ (thin solid), 0.5 (thin dashed), 1 (thin wide dashed), 2 (thick dashed) and 4 (thick solid) for (a) EUT $(\alpha=0.75$ ) and (b) PT $(\lambda=1.5$ and $\alpha=0.75)$. We assume no recency bias $(\rho=1)$ and $\omega=1.0$

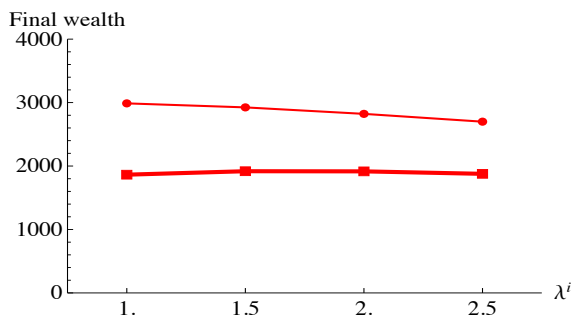

Figure II.3: Final wealth and $\lambda^{i}$ when frequency of tail-event is less than 2 (thin solid) and more than 3 (thick solid).

\section{Robustness Checks for Hypotheses}

The results of sensitivity analyses for each hypothesis will be provided below. In line with our first four hypotheses, we first focus on the change in bids as a result of observing or suffering a tail event. Let $\Delta b=b_{\tau+1}-b_{\tau}$, where $\tau$ is the period in which the first tail event was observed.

\section{III.1 Hypothesis 1}

Our robustness checks vary (1) the prior probability for the tail event $(\pi),(2)$ the weight for the prior $(\eta)$, and (3) the degree of risk and loss aversion $(\alpha$ and $\lambda$ ).

Figure III.1.1 shows the relationship between $\Delta b$ and the prior for the tail event, $\pi$, in case risk-averse investors observed the tail event without suffering tail losses, under EUT with $\alpha=0.75$ (panel (a)) and PT with $\alpha=0.75$ and $\lambda=1.5$ (panel (b)). In each panel, four combinations of weights for the prior $(\eta, 100$ (thin) vs. 300 (thick)) and the recency bias $(\rho, 1.0$ (solid) vs. 0.5 (dashed)) are considered. Thus in the figure, a thin solid line stands for $(\eta, \rho)=(100,1.0)$, a thick dashed line is for $(\eta, \rho)=(300,0.5)$, etc.

Two observations can be derived from Figure III.1.1. First, the magnitude of the drop in bids is smaller when $\eta=300$ (thick lines) than when $\eta=100$ (thin lines) for both values of $\rho$, regardless of the value of $\pi$. $\Delta b$ is negative for this set of parameters which shows the robustness of Hypothesis 1 according to which bids tend to decrease after a tail event has been observed yet not suffered. This is straightforward: the 
(a) $\operatorname{EUT}(\alpha=0.75)$

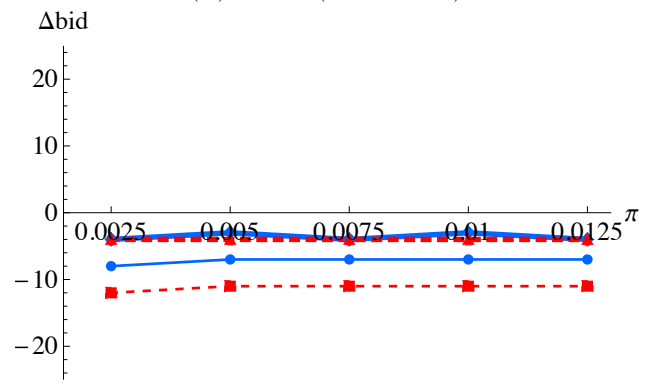

(b) $\operatorname{PT}(\alpha=0.75, \lambda=0.75)$

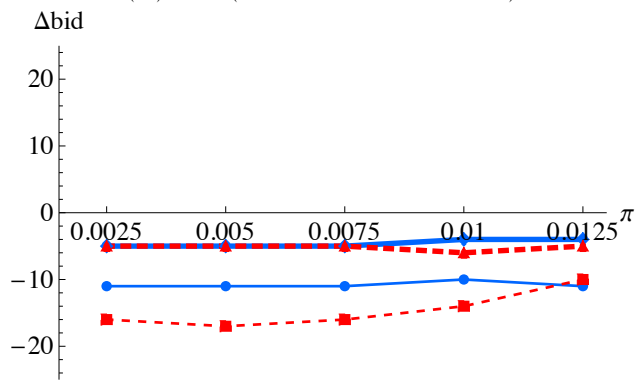

Figure III.1.1: Relationship between the change in bids after observing (but not suffering) the tail-event $(\Delta b)$ and the prior for the tail-event $(\pi)$ for two values of weight for the prior $\eta=100$ (thin) and 300 (thick) and two values of recency bias $\rho=1.0$ (solid) and 0.5 (dashed). (a) risk averse EUT ( $\alpha=0.75$ ) and (b) risk averse PT $(\alpha=0.75, \lambda=1.5)$
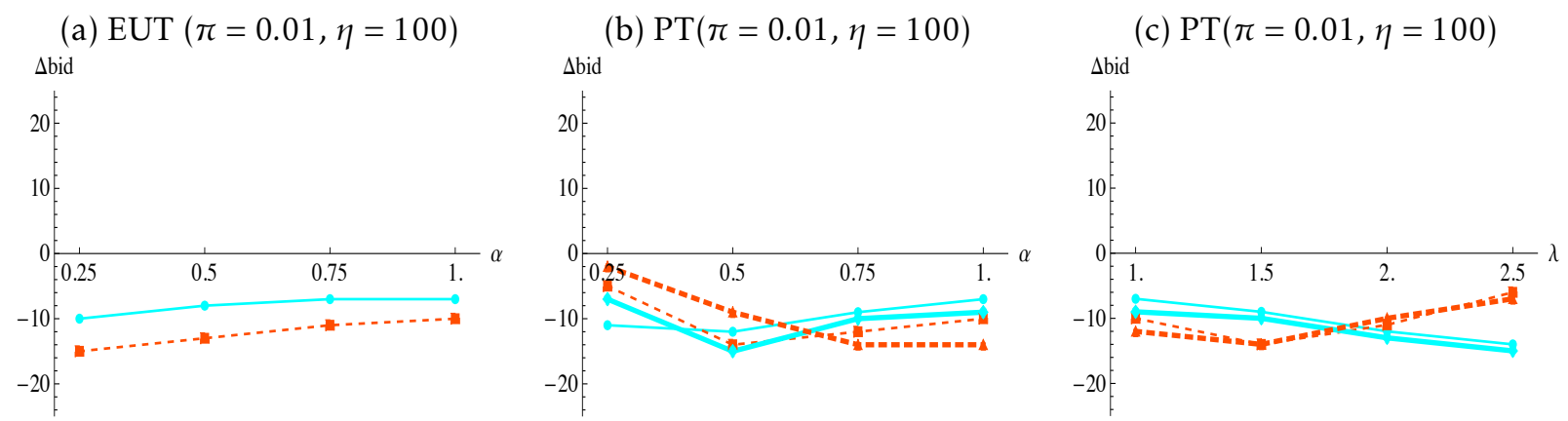

Figure III.1.2: Relationship between the change in bids after observing (but not suffering) the tail event $(\Delta b)$ and degree of risk (panel a and b) and loss aversion (panel c) for two values of recency bias $\rho=1.0$ (solid) and 0.5 (dashed). (a) EUT, (b) PT ( $\lambda=1.0$ (thin) and $\lambda=1.5$ (thick)), (c) PT ( $\alpha=1.0$ (thin) and $\alpha=0.75$ (thick))

higher the weight of the prior, the smaller is the impact of the tail event on the bid. Second, the magnitude of changes in bids, $|\Delta b|$, is larger for $\rho=0.5$ (dashed lines) than for $\rho=1.0$ (solid lines) for both values of $\eta$, although the differences are smaller for $\eta=300$. Thus, Hypothesis 1 is robust to variations in the weights on the prior and in the value of the prior probability of the tail event, while holding the preference parameters constant.

Now we fix $\eta=100$ and $\pi=0.01$ and vary $\alpha$ and $\lambda$. Figure III.1.2 shows the relationship between $\Delta b$ and the degree of risk aversion $\alpha$ for two values of $\rho$ (1.0 (solid lines) vs. 0.5 (dashed lines)) for EUT investors (panel (a)) and for PT investors (panels (b) and (c)) with two values of $\lambda$ (1.0 (thin line) and 1.5 (thick line)). Panel (c) in Figure III.1.2 shows the relationship between $\Delta b$ and the degree of loss aversion $\lambda$ for two values of $\rho$ (1.0 (solid line) vs. 0.5 (dashed line)) with two values of $\alpha$ (1.0 (thin line) and 0.75 (thick line)).

For EUT investors (panel (a)), the magnitude of the change in bids $|\Delta b|$, is larger for $\rho=0.5$ (dashed line) than for $\rho=1.0$ (solid) for all the four values of $\alpha$ considered. For PT investors, $|\Delta b|$ is larger for $\rho=0.5$ 
(a) $\alpha=0.25, \lambda=1.0$

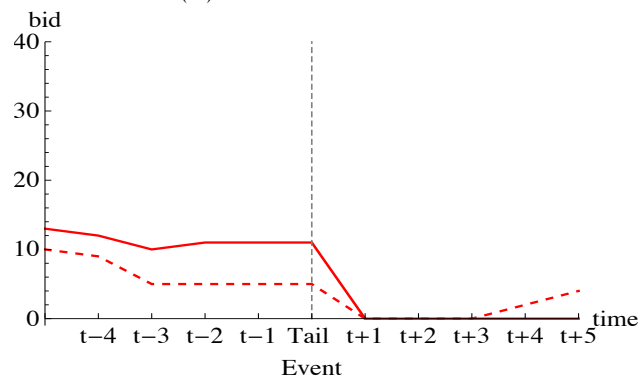

(c) $\alpha=0.25, \lambda=2.0$

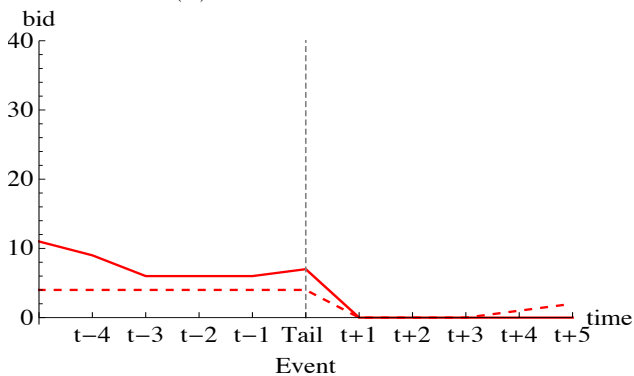

(b) $\alpha=0.75, \lambda=1.0$

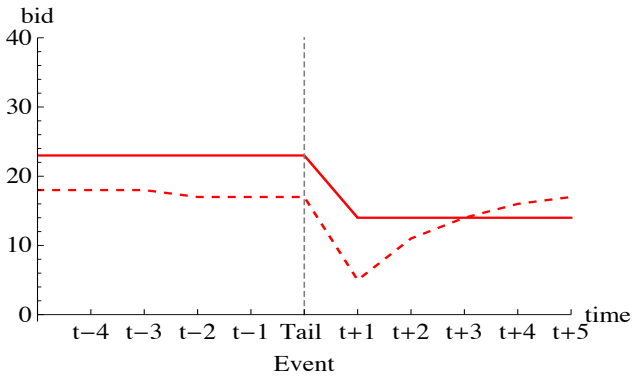

(d) $\alpha=0.75, \lambda=2.0$

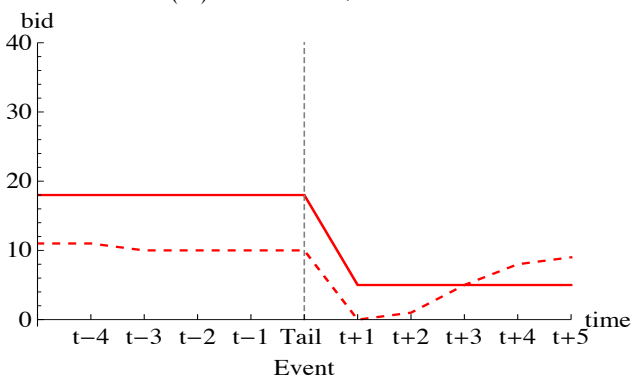

Figure III.1.3: Dynamics of bids around the (observed but not suffered) tail event for two values of $\rho$ (1.0 (solid) and 0.5 (dashed)) with PT agents with four combinations of the degree of risk $(\alpha \in 0.25,0.75)$ and loss aversion $(\lambda \in 1.0,2.0)$.

(dashed line) than for $\rho=1.0$ (solid line) for $\alpha=0.75$ and 1.0, but not necessarily so for the other values of $\alpha$ (panel (b)). Furthermore, for the PT investors, $|\Delta b|$ is larger for $\rho=0.5$ (dashed line) than for $\rho=1.0$ (solid line) for $\lambda=1.0$ or 1.5, but not for the larger value of $\lambda$ (panel (c)). These observations suggest that, for some range of parameters, the model does not support the second part of Hypothesis 1. But this is due to bids reaching the lower bound (i.e., zero) after the tail event as one can observe in Figure III.1.3 that shows that PT investors with small values of $\alpha$ or high values of $\lambda$ (panels (a), (c), and (d)) may respond to the tail event by bidding zero afterwards. But because their pre-tail event levels are low, especially when there is a recency bias $(\rho=0.5),|\Delta b|$ values can become smaller for investor with recency bias $(\rho=0.5)$ than those without $\rho=1.0$ contrary to Hypothesis 1 .

\section{III.2 Hypothesis 2}

As for Hypothesis 1, we vary (1) the prior probability for the tail event $(\pi),(2)$ the weight for the prior $(\eta)$, and (3) degree of risk and loss aversion $(\alpha$ and $\lambda$ ).

Figure III.2.1 shows the relationship between $\Delta b$ and the prior for the tail event $\pi$, in case the tail event was both observed and suffered by risk-averse EUT investors with $\alpha=0.75$ (panel (a)) and risk-averse PT investors with $\alpha=0.75, \lambda=1.5$ (panel (b)). In each panel, four combinations of weights for the prior $(\eta$, 100 (thin) vs. 300 (thick)) and the recency bias ( $\rho, 1.0$ (solid) vs. 0.5 (dashed)) are considered.

Two observations can be derived from Figure III.2.1. First, for PT investors, bids increase after suffering from the tail event, and the magnitude of the increase tends to be larger when $\rho=0.5$ (dashed line) than 
(a) $\operatorname{EUT}(\alpha=0.75)$

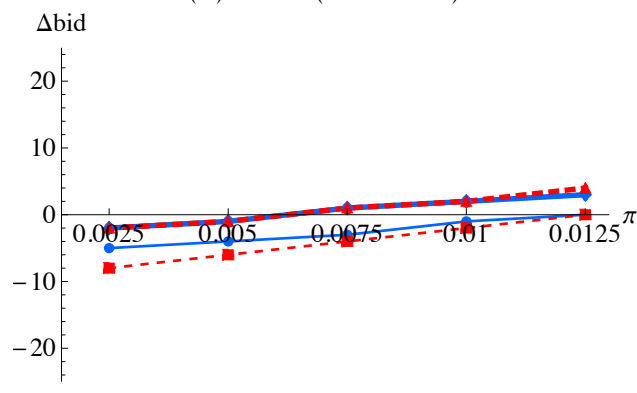

(b) PT $(\alpha=0.75, \lambda=1.5)$

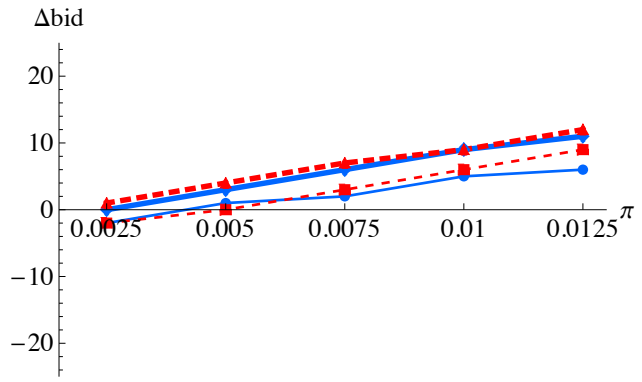

Figure III.2.1: Relationship between the change in bids after observing (and suffering) the tail event $(\Delta b)$ and the prior for the tail event $(\pi)$ for two values of weight for the prior $\eta=100$ (thin) and 300 (thick) and two values of recency bias $\rho=1.0$ (solid) and 0.5 (dashed). (a) risk averse EUT ( $\alpha=0.75$ ) and (b) risk-averse PT $(\alpha=0.75, \lambda=1.5)$
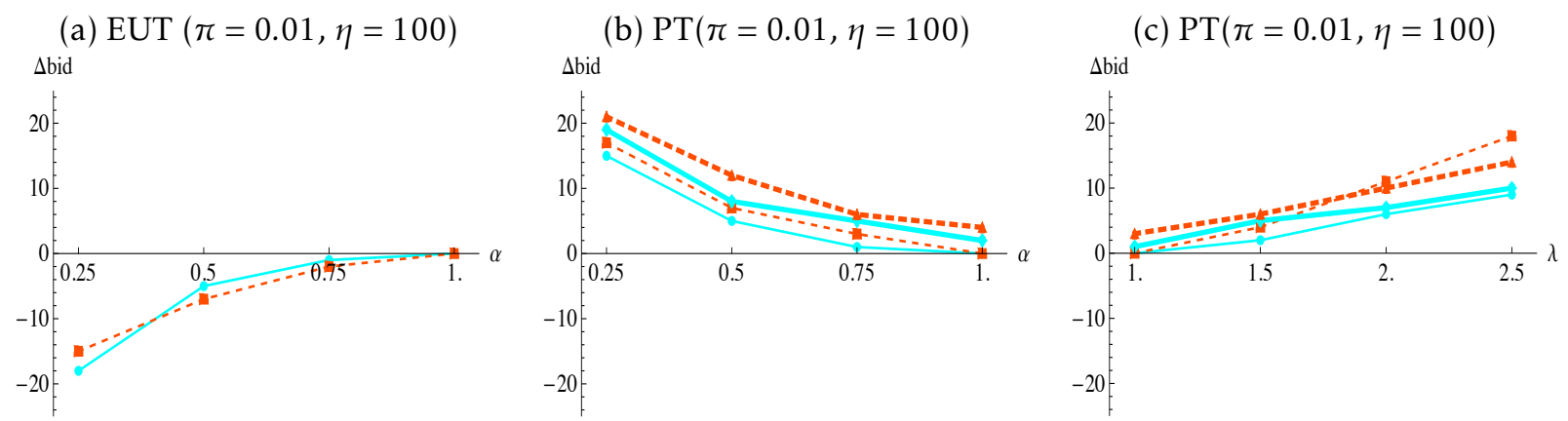

Figure III.2.2: Relationship between the change in bids after observing (and suffering) the tail event $(\Delta b$ ) and degree of risk (panels (a) and (b)) and loss aversion (panel (c)) for two values of recency bias $\rho=1.0$ (solid) and 0.5 (dashed). (a) EUT, (b) PT ( $\lambda=1.0$ (thin) and $\lambda=1.5$ (thick)), (c) PT ( $\alpha=1.0$ (thin) and $\alpha=0.75$ (thick))

when $\rho=1.0$ (solid line). Second, even EUT investors can increase their bid as a result of suffering the tail event, which is due to the limited liability.

Now we fix the $\eta=100$ and $\pi=0.01$ and vary $\alpha$ and $\lambda$. Figure III.2.2 shows the relationship between $\Delta b$ and the degree of risk aversion $\alpha$ for two values of $\rho$ (1.0 (solid line) vs 0.5 (dashed line)) for EUT investors (panel (a)) and PT investors (panel (b)) with two values of $\lambda$ (1.0 (thin line) and 1.5 (thick line)). Figure III.2.2 shows the relationship between $\Delta b$ and the degree of loss aversion, $\lambda$, for two values of $\rho(1.0$ (solid line) vs. 0.5 (dashed line)) with two values of $\alpha$ (1.0 (thin line) and 0.75 (thick line)) (panel (c)).

For EUT investors (panel (a)), bids decrease less when risk aversion decreases (i.e., the larger $\alpha$ ). For PT investors, bids increase less for a larger $\alpha$ and a smaller $\lambda$. In addition, for PT investors, except when $\alpha=1.0$ and $\lambda=1.0$, the increase in bids is larger for $\rho=0.5$ (dashed line) than for $\rho=1.0$ (solid line). $\Delta b$ is positive for a large set of parameters which shows the robustness of Hypothesis 2 according to which bids tend to increase after a tail event has been observed and suffered. 
(a) $\lambda=1.5$

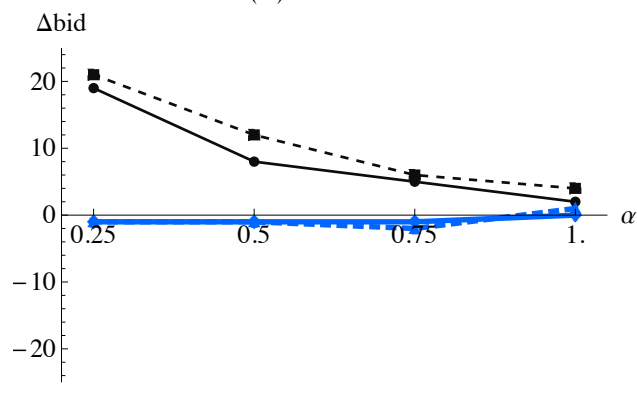

(b) $\alpha=0.75$

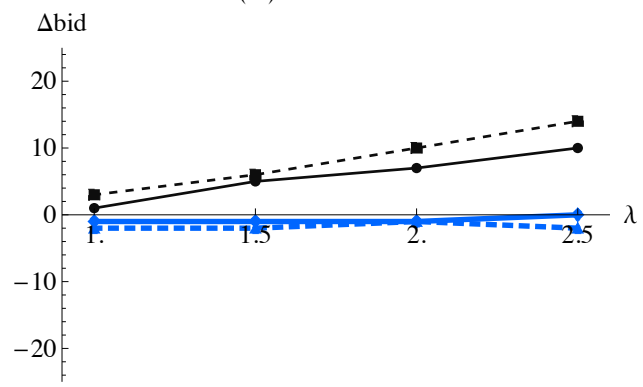

Figure C.3.1: Relationship between the change in bids after observing (and suffering) the tail event $(\Delta b$ ) and degree of risk (panel (a)) and loss aversion (panel (b)) for two values of $\omega(1.0$ (thin) and 0.0 (thick)) and $\rho(1.0$ (solid) and 0.5 (dashed)).

(a) $\lambda=1.5$

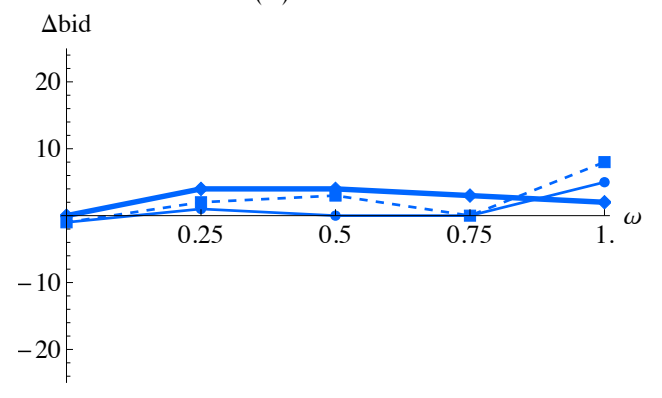

(b) $\alpha=0.75$

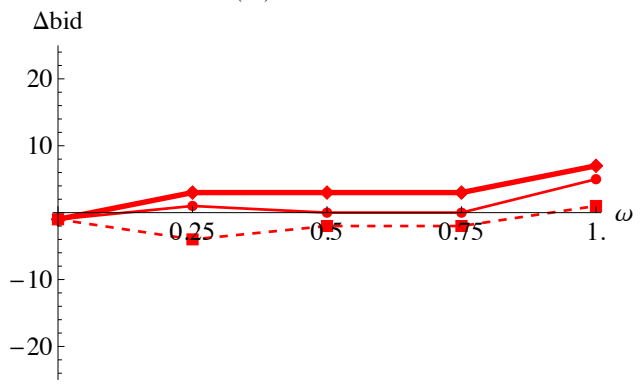

Figure C.3.2: Relationship between the change in bids after observing (and suffering) the tail event $(\Delta b)$ and $\omega$ for (a) three values of $\alpha$ (1.0 (thick), 0.75 (thin solid), and 0.5 (thin dashed) with $\lambda=1.5$ ), and (b) three values of $\lambda$ (2.0 (thick), 1.5 (thin solid), and 1.0 (thin dashed) with $\alpha=0.75$ ). In both panels we set $\rho=1.0$.

\section{III.3 Hypothesis 3}

We fix the $\eta=100$ and $\pi=0.01$ and vary $\alpha$ and $\lambda$ to see the robustness of the effect of $\omega$.

Figure C.3.1 shows the relationship between $\Delta b$ and $\alpha$ (with $\lambda=1.5$ ) (panel (a)), and between $\Delta b$ and $\lambda$ (with $\alpha=0.75$ ) (panel (b)). In each panel, four combinations of $\omega$ (1.0 (thin lines) and 0.0 (thick lines)) and $\rho$ (1.0 (solid lines) and 0.5 (dashed lines)) are considered. Thus, thin solid lines in the figure stand for $(\omega, \rho)=(1.0,1.0)$, and thick dashed lines stand for $(\omega, \rho)=(0.0,0.5)$. The figure shows that the increase in bids as a result of suffering from the tail event is not observed for $\omega=0.0$.

Figure C.3.2 shows the relationship between $\Delta b$ and $\omega$ while varying $\alpha$ (panel (a)) and $\lambda$ (panel (b)). The increase in bids due to suffering the tail event is mitigated when $\omega$ equals 0.75 , and it remains at a similar level for $\omega \in\{0.25,0.5,0.75\}$ before declining even further at $\omega=0.0$. Similar results are obtained for $\rho=0.5$ as well. Thus, Hypothesis 3 is robust to changes in parameter values. 
(a) Tail-event not suffered

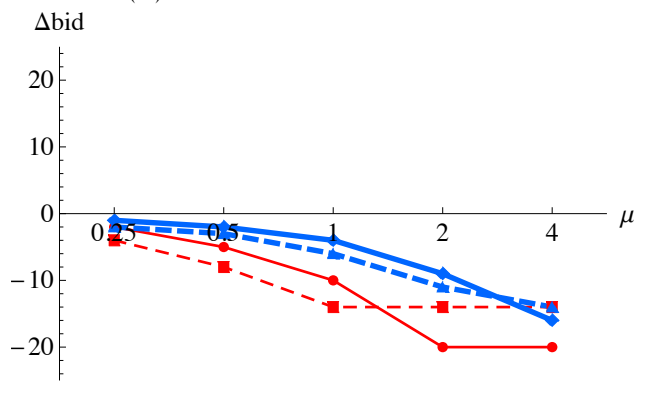

(b) Tail-event suffered

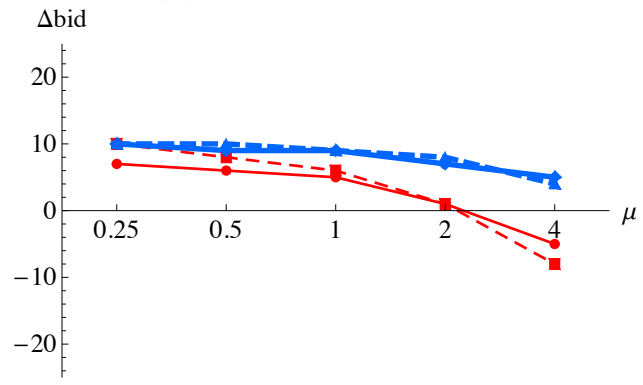

Figure III.4.1: Relationship between $(\Delta b)$ and $\mu$ for four combinations of $\eta(100$ (thin) vs. 300 (thick)) and $\rho(1.0$ (solid) vs. 0.5 (dashed)), for investors not suffering (panel (a)) and suffering (panel (b)) the tail event. $\lambda=1.5, \alpha=0.75, \omega=1.0$, and $\pi=0.01$

(a) Tail-event not suffered

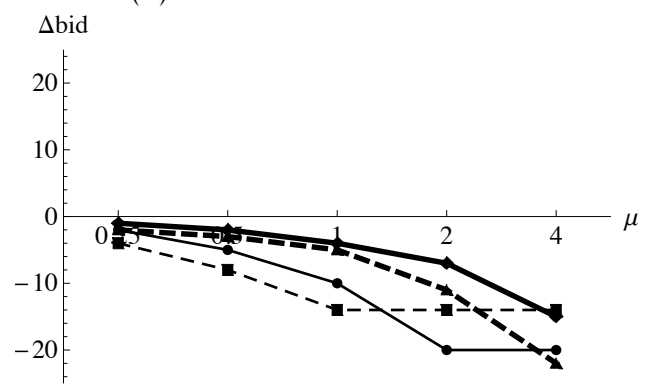

(b) Tail-event suffered

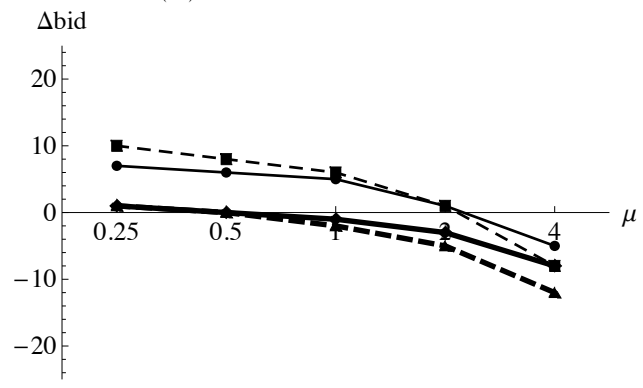

Figure III.4.2: Relationship between $(\Delta b)$ and $\mu$ for four combinations of $\omega(1.0$ (thin) vs 0.0 (thick)) and $\rho$ $(1.0$ (solid) v.s. 0.5 (dashed)), for investors not suffering (panel (a)) and suffering (panel (b)) the tail event. $\lambda=1.5, \alpha=0.75, \pi=0.01, \eta=100$

\section{III.4 Hypothesis 4}

Here we consider the effect of varying $\mu$ in various combination of parameters.

PT investors.

Figure III.4.1 plots the relationships between $\Delta b$ and $\mu$ for four combinations of $\eta$ (100 (thin lines) vs. 300 (thick lines)) and $\rho$ (1.0 (solid lines) vs. 0.5 (dashed lines)) for PT investors (with $\lambda=1.5$ and $\alpha=0.75$ who suffered (panel (b)) and did not suffer (panel (a)) the tail event. Thus, $(\eta, \rho)=(100,1.0)$ is shown in thin solid line, $(\eta, \rho)=(300,0.5)$ in thick dashed line.

Figure III.4.1 exhibits a negative relationship between $\Delta b$ and $\mu$ for all four combinations of $\eta$ and $\rho$, regardless of whether investors suffered or not the tail event. Note that $\Delta b$ becomes the same for $\mu=\{1,2,4\}$ for $(\eta, \rho)=(100,1.0)$ or for $\mu=\{2,4\}$ for $(\eta, \rho)=(100,0.5)$ in panel (a), because investors reduced their bid to zero after observing the tail event, while the pre-tail event bids were similar in all of these cases.

Figure III.4.2 plots the relationships between $\Delta b$ and $\mu$ for four combinations of $\omega$ (1.0 (thin lines) vs. 0.0 (thick lines)) and $\rho$ (1.0 (solid lines) vs. 0.5 (dashed lines)) for investors who suffered (panel (b)) and did not suffer (panel (a)) the tail event. Thus, $(\omega, \rho)=(1.0,1.0)$ is shown in thin solid lines, $(\omega, \rho)=(0.0,0.5)$ 
(a) Tail-event not suffered

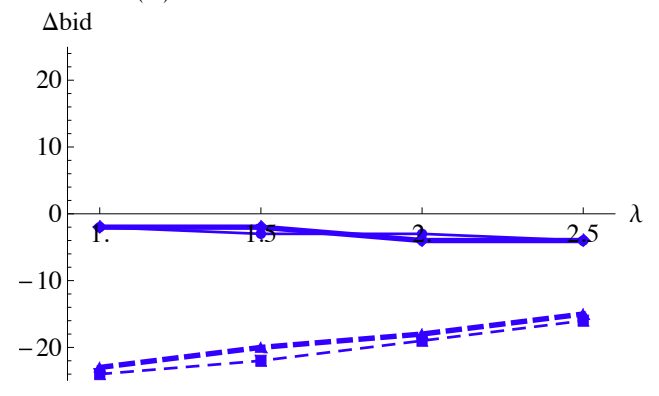

(b) Tail-event suffered

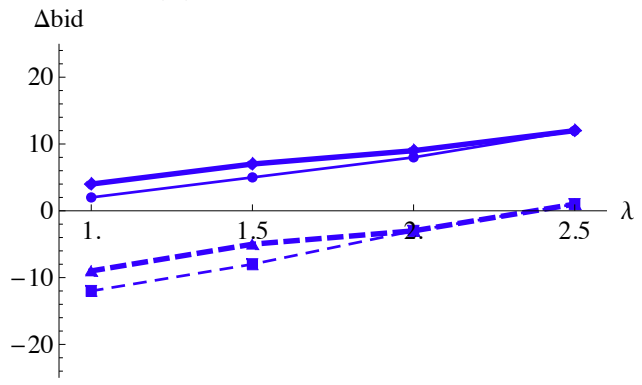

Figure III.4.3: Relationship between $(\Delta b)$ and $\lambda$ for four combinations of $\alpha(1.0$ (thin) vs 0.75 (thick)) and $\mu$ $(0.25$ (solid) v.s. 4.0 (dashed)), for investors not suffering (panel (a)) and suffering (panel (b)) the tail event. $\pi=0.01, \eta=100, \rho=1.0, \omega=1.0$

(a) Tail-event not suffered

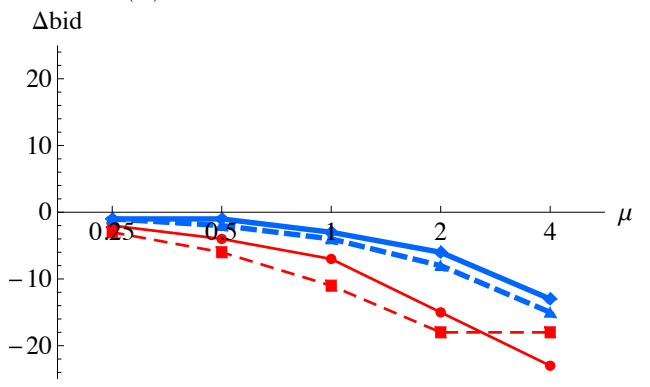

(b) Tail-event suffered

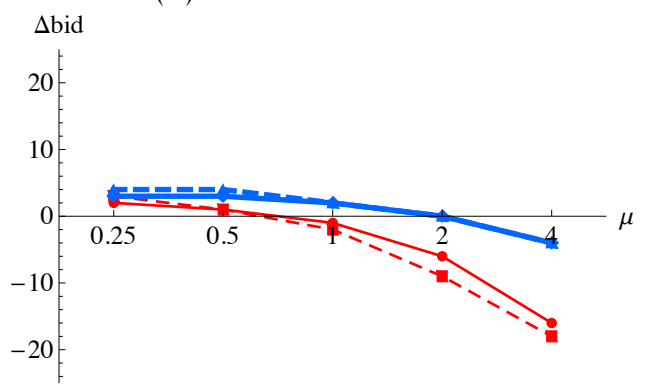

Figure III.4.4: Relationship between $(\Delta b)$ and $\mu$ for four combinations of $\eta(100$ (thin) vs 300 (thick)) and $\rho(1.0$ (solid) v.s. 0.5 (dashed)) for EUT investors, not suffering (panel (a)) and suffering (panel (b)) the tail event. $\alpha=0.75$ and $\pi=0.01$

in thick dashed line. Figure III.4.2 shows that there is a negative relationship between the $\Delta b$ and $\mu$ for all the four combinations of $\omega$ and $\rho$, regardless of whether investors suffered or not the tail event. As in Figure III.4.1, there are cases where $\Delta b$ becomes the same for $\mu \geq 1.0$, because investors reduced their bid to zero after observing the tail event, and the pre-tail event bids were similar in all of these cases.

Figure III.4.3 reports the relationship between $\Delta b$ and $\lambda$ for four combinations of $\alpha$ (1.0 (thin lines) vs. 0.75 (thick lines)) and $\mu(0.25$ (solid lines) vs. 4.0 (dashed lines)) for investors who suffered (panel (b)) and did not suffer (panel (a)) the tail event. Thus, $(\alpha, \mu)=(1.0,0.25)$ is shown in thin solid lines, $(\alpha, \mu)=(0.75,4.0)$ in thick dashed lines. Figure III.4.3 shows that the solid lines $(\mu=0.25)$ are above the dashed line $(\mu=4.0)$ for all the values of $\lambda$ and $\alpha$ regardless of whether investors suffered the tail event or not. Thus, for PT, the Hypotheses $4 \mathrm{i}$ and $4 \mathrm{ii}$ are both robust against variations in the parameter values.

\section{EUT investors.}

Figure III.4.4 presents the relationships between $\Delta b$ and $\mu$ for four combinations of $\eta$ (100 (thin lines) vs. 300 (thick lines)) and $\rho$ (1.0 (solid lines) vs. 0.5 (dashed lines)) for risk-averse EUT investors $(\alpha=0.75)$ who suffered (panel (b)) and did not suffer (panel (a)) the tail event. Thus, $(\eta, \rho)=(100,1.0)$ is shown in 
(a) Tail-event not suffered

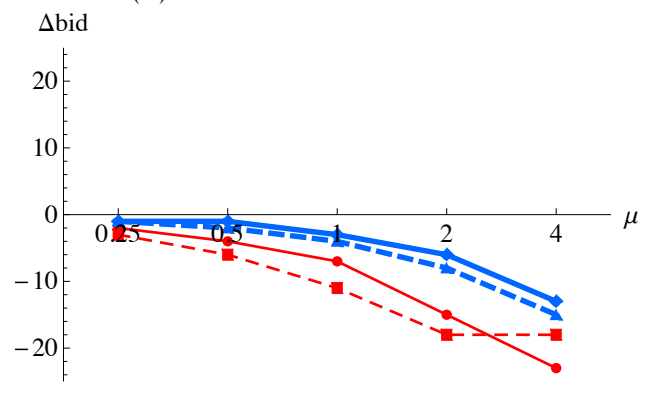

(b) Tail-event suffered

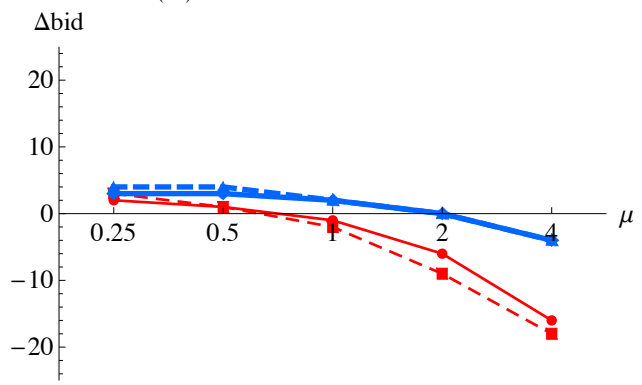

Figure III.4.5: Relationship between $(\Delta b)$ and $\alpha$ for four combinations of $E \mu(0.25$ (thin) vs 4.0 (thick)) and $\rho(1.0$ (solid) v.s. 0.5 (dashed)) for EUT investors not suffering (panel (a)) and suffering (panel (b)) the tail event. $\pi=0.01, \eta=100$

thin solid lines, $(\eta, \rho)=(300,0.5)$ in thick dashed lines. The results are qualitatively the same as in the case of PT investors considered in Figure III.4.1.

Figure III.4.5 reports the relationships between $\Delta b$ and $\alpha$ for four combinations of $\mu$ ( 0.25 (thin lines) vs. 4.0 (thick lines)) and $\rho(1.0$ (solid lines) vs. 0.5 (dashed lines)) for EUT investors who suffered (panel (b)) and did not suffer (panel (a)) the tail event. Thus, $(\mu, \rho)=(0.25,1.0)$ is shown in thin solid line, $(\mu, \rho)=(4.0,0.5)$ is shown in thick dashed line. Figure III.4.5 shows that the thin lines $(\mu=0.25)$ are above the thick lines $(\mu=4.0)$ for all the values of $\alpha$ and $\rho$, regardless of whether the investor suffered the tail event or not. Thus, for EUT as well, Hypotheses $4 \mathrm{i}$ and $4 \mathrm{ii}$ are both robust against variations in the parameter values.

We do not conduct specific robust checks for Hypothesis 5 because it is already derived for an average of a broad set of parameters of the model (see Appendix II.1 for simulation details). 


\section{Robustness Checks for Results}

In this online appendix, we assess the robustness of our findings after controlling for individual characteristics such as investors' attitudes toward risk, losses and ambiguity. We also show that our findings are robust to controlling for potential autocorrelation issues which could have been produced by the inertia of investors' decisions across periods. Regarding potential selection issues associated with the occurrence of bankruptcy in our experiment, we also redid our analysis by considering only cases in which bankruptcy could not occur (i.e. occurrence of less than two tail events).

\section{IV.1 Hypothesis 1}

Table IV.1.1: Decrease in Bids, Alternative Definitions of Availability Bias and Tail Events. Panel probit regressions with random effects and robust standard errors clustered at the individual levels in parentheses, session fixed effects included.

\begin{tabular}{|c|c|c|c|}
\hline \multirow{3}{*}{$\begin{array}{l}\text { VARIABLE } \\
\text { SAMPLE } \\
\text { (Investors did not buy asset in previous } \\
\text { period) }\end{array}$} & \multicolumn{3}{|c|}{ DOWN DUMMY } \\
\hline & (1) & $(2)$ & (3) \\
\hline & $\begin{array}{l}\text { Availability Score = } \\
\text { Availability Index }\end{array}$ & $\begin{array}{l}\text { Availability Score = } \\
\text { Availability Test Score } \\
\text { I }\end{array}$ & $\begin{array}{l}\text { Availability Score = } \\
\text { Availability Test Score } \\
\text { II }\end{array}$ \\
\hline \multirow[t]{2}{*}{ Tail Event Dummy } & $0.305^{\star *}$ & 0.431 & $-3.281^{\star \star}$ \\
\hline & $(0.151)$ & $(0.320)$ & $(1.335)$ \\
\hline \multirow[t]{2}{*}{ Tail Event Dummy $\times$ Availability Score } & $0.284^{* *}$ & 0.054 & $6.905^{* * *}$ \\
\hline & $(0.143)$ & $(0.131)$ & $(2.565)$ \\
\hline \multirow[t]{2}{*}{ Availability Score } & 0.069 & 0.077 & $6.905^{* * *}$ \\
\hline & $(0.080)$ & $(0.067)$ & $(2.565)$ \\
\hline \multirow[t]{2}{*}{ Period } & $-0.001^{\star *}$ & $-0.001^{* *}$ & $-0.001^{\star *}$ \\
\hline & $(0.001)$ & $(0.000)$ & $(0.000)$ \\
\hline \multirow[t]{2}{*}{ Number of Tail Events } & 0.016 & 0.017 & 0.016 \\
\hline & $(0.034)$ & $(0.034)$ & $(0.034)$ \\
\hline \multirow[t]{2}{*}{ Constant } & $-0.841^{* * *}$ & $-0.683^{* *}$ & -1.114 \\
\hline & $(0.304)$ & $(0.318)$ & $(0.771)$ \\
\hline Observations & 13,793 & 13,793 & 13,793 \\
\hline Number of Investors & 86 & 86 & 86 \\
\hline
\end{tabular}

${ }^{* * *} \mathrm{p}<0.01,{ }^{* *} \mathrm{p}<0.05,{ }^{*} \mathrm{p}<0.1$ 
Table IV.1.2: Decrease in Bids, Recency Bias and Tail Events. Panel probit regressions with random effects and robust standard errors clustered at the individual levels in parentheses, session fixed effects included.

\begin{tabular}{|c|c|c|c|}
\hline VARIABLE & \multicolumn{3}{|c|}{ DOWN DUMMY } \\
\hline \multirow[b]{2}{*}{$\begin{array}{l}\text { SAMPLE } \\
\text { (Investors did not buy asset in previous period) }\end{array}$} & (1) & (2) & (3) \\
\hline & $\begin{array}{l}\text { High Recency Bias } \\
\text { (Above-median } \\
\text { recency scores) }\end{array}$ & \multicolumn{2}{|l|}{$\begin{array}{l}\text { Low Recency Bias } \\
\text { (Below-median } \\
\text { recency scores) }\end{array}$} \\
\hline \multirow[t]{2}{*}{ Tail Event Dummy } & $0.544^{*}$ & 0.236 & 0.240 \\
\hline & $(0.301)$ & $(0.167)$ & $(0.168)$ \\
\hline \multirow[t]{2}{*}{ Tail Event Dummy $\times$ High Recency Dummy } & \multirow[t]{2}{*}{-} & \multirow[t]{2}{*}{-} & 0.102 \\
\hline & & & $(0.178)$ \\
\hline \multirow[t]{2}{*}{ High Recency Dummy } & \multirow[t]{2}{*}{-} & \multirow[t]{2}{*}{-} & -0.270 \\
\hline & & & $(0.337)$ \\
\hline \multirow[t]{2}{*}{ Period } & -0.001 & $-0.001^{* *}$ & $-0.001^{* *}$ \\
\hline & $(0.001)$ & $(0.000)$ & $(0.000)$ \\
\hline \multirow[t]{2}{*}{ Number of Tail Events } & -0.033 & 0.028 & 0.016 \\
\hline & $(0.078)$ & $(0.038)$ & $(0.034)$ \\
\hline \multirow[t]{2}{*}{ Constant } & $-1.238^{\star *}$ & $-0.504^{* * *}$ & $-0.783^{* * *}$ \\
\hline & $(0.611)$ & $(0.136)$ & $(0.287)$ \\
\hline Observations & 4,100 & 9,693 & 13,793 \\
\hline Number of Investors & 27 & 59 & 86 \\
\hline Prob $>$ Chi-squared & 4,100 & 9,693 & 13,793 \\
\hline
\end{tabular}

${ }^{* * *} \mathrm{p}<0.01,{ }^{* *} \mathrm{p}<0.05,{ }^{*} \mathrm{p}<0.1$

The high recency dummy takes value one if a person scores above the median of all participants' scores. 
Table IV.1.3: Decrease in Bids, Availability Bias, Individual Controls and Tail Events. Panel probit regressions with random effects and robust standard errors clustered at the individual levels in parentheses, session fixed effects included.

\begin{tabular}{|c|c|c|c|c|}
\hline \multirow[b]{2}{*}{$\begin{array}{l}\text { VARIABLE } \\
\text { SAMPLE } \\
\text { (Investors did not buy asset in previous pe- } \\
\text { riod) }\end{array}$} & \multicolumn{4}{|c|}{ DOWN DUMMY } \\
\hline & $\begin{array}{l}\text { (1) } \\
\text { All }\end{array}$ & $\begin{array}{l}\text { (2) } \\
\text { Low Availability } \\
\text { Bias }\end{array}$ & $\begin{array}{l}(3) \\
\text { High Availabil- } \\
\text { ity Bias }\end{array}$ & $\begin{array}{l}\text { (4) } \\
\text { All }\end{array}$ \\
\hline Tail Event Dummy & $\begin{array}{l}0.324^{* *} \\
(0.149)\end{array}$ & $\begin{array}{l}0.417^{\star} \\
(0.234)\end{array}$ & $\begin{array}{l}0.213 \\
(0.186)\end{array}$ & $\begin{array}{l}0.214 \\
(0.185)\end{array}$ \\
\hline Tail Event $\times$ High Availability Dummy & - & - & - & $\begin{array}{l}0.211 \\
(0.298)\end{array}$ \\
\hline High Availability Dummy & - & - & - & $\begin{array}{l}-0.137 \\
(0.215)\end{array}$ \\
\hline Period & $\begin{array}{l}-0.001^{* *} \\
(0.000)\end{array}$ & $\begin{array}{l}-0.000 \\
(0.001)\end{array}$ & $\begin{array}{l}-0.002^{* *} \\
(0.001)\end{array}$ & $\begin{array}{l}-0.001^{* *} \\
(0.000)\end{array}$ \\
\hline Number of Tail Events & $\begin{array}{l}0.018 \\
(0.034)\end{array}$ & $\begin{array}{l}0.006 \\
(0.049)\end{array}$ & $\begin{array}{l}0.035 \\
(0.049)\end{array}$ & $\begin{array}{l}0.018 \\
(0.034)\end{array}$ \\
\hline Male (std) & $\begin{array}{l}-0.063 \\
(0.074)\end{array}$ & $\begin{array}{l}-0.029 \\
(0.135)\end{array}$ & $\begin{array}{l}-0.081 \\
(0.105)\end{array}$ & $\begin{array}{l}-0.063 \\
(0.074)\end{array}$ \\
\hline Availability Index (std) & $\begin{array}{l}0.098 \\
(0.079)\end{array}$ & $\begin{array}{l}0.670^{* * *} \\
(0.190)\end{array}$ & $\begin{array}{l}0.380^{*} \\
(0.204)\end{array}$ & $\begin{array}{l}0.156 \\
(0.132)\end{array}$ \\
\hline Loss Aversion (std) & $\begin{array}{l}0.114 \\
(0.080)\end{array}$ & $\begin{array}{l}0.005 \\
(0.107)\end{array}$ & $\begin{array}{l}0.381^{* * *} \\
(0.133)\end{array}$ & $\begin{array}{l}0.120 \\
(0.083)\end{array}$ \\
\hline Risk Aversion (std) & $\begin{array}{l}-0.046 \\
(0.057)\end{array}$ & $\begin{array}{l}-0.019 \\
(0.115)\end{array}$ & $\begin{array}{l}-0.195^{\star * *} \\
(0.059)\end{array}$ & $\begin{array}{l}-0.048 \\
(0.057)\end{array}$ \\
\hline Ambiguity Aversion (std) & $\begin{array}{l}-0.019 \\
(0.033)\end{array}$ & $\begin{array}{l}0.074 \\
(0.048)\end{array}$ & $\begin{array}{l}-0.099^{* * *} \\
(0.036)\end{array}$ & $\begin{array}{l}-0.019 \\
(0.033)\end{array}$ \\
\hline Bayesian Updating Score (std) & $\begin{array}{l}-0.011 \\
(0.066)\end{array}$ & $\begin{array}{l}-0.150 \\
(0.205)\end{array}$ & $\begin{array}{l}0.074 \\
(0.075)\end{array}$ & $\begin{array}{l}-0.012 \\
(0.065)\end{array}$ \\
\hline CRT score (std) & $\begin{array}{l}-0.137^{\star *} \\
(0.068)\end{array}$ & $\begin{array}{l}0.148 \\
(0.123)\end{array}$ & $\begin{array}{l}-0.110 \\
(0.068)\end{array}$ & $\begin{array}{l}-0.140^{* *} \\
(0.069)\end{array}$ \\
\hline Emotionality Score (std) & $\begin{array}{l}0.051 \\
(0.089)\end{array}$ & $\begin{array}{l}0.187 \\
(0.134)\end{array}$ & $\begin{array}{l}-0.199^{* *} \\
(0.095)\end{array}$ & $\begin{array}{l}0.041 \\
(0.088)\end{array}$ \\
\hline Prior Tail Events (std) & $\begin{array}{l}-0.044 \\
(0.074)\end{array}$ & $\begin{array}{l}0.129^{* *} \\
(0.062)\end{array}$ & $\begin{array}{l}0.101 \\
(0.090)\end{array}$ & $\begin{array}{l}-0.043 \\
(0.074)\end{array}$ \\
\hline Constant & $\begin{array}{l}-0.908^{* * *} \\
(0.298)\end{array}$ & $\begin{array}{l}-1.823^{* * *} \\
(0.537)\end{array}$ & $\begin{array}{l}-0.576^{* * *} \\
(0.205)\end{array}$ & $\begin{array}{l}-0.833^{* * *} \\
(0.277)\end{array}$ \\
\hline Observations & 13,695 & 6,708 & 6,987 & 13,695 \\
\hline Number of investors & 85 & 41 & 44 & 85 \\
\hline
\end{tabular}

${ }^{* *} \mathrm{p}<0.01,{ }^{* *} \mathrm{p}<0.05,{ }^{*} \mathrm{p}<0.1$ 
Table IV.1.4: Decrease in Bids, Availability Bias, Autocorrelation and Tail Events. Panel linear regressions with $\mathrm{AR}(1)$ error terms and random effects and robust standard errors clustered at the individual levels in parentheses, session fixed effects included.

\begin{tabular}{|c|c|c|c|c|}
\hline VARIABLE & & DOWN & MMY & \\
\hline $\begin{array}{l}\text { SAMPLE } \\
\text { (Investors did not buy asset in previous period) }\end{array}$ & $(1)$ & $\begin{array}{l}(2) \\
\text { High } \\
\text { Availability Bias }\end{array}$ & $\begin{array}{l}(3) \\
\text { Low } \\
\text { Availability Bias }\end{array}$ & $(4)$ \\
\hline Tail Event Dummy & $\begin{array}{l}0.116^{* * *} \\
(0.039)\end{array}$ & $\begin{array}{l}0.138^{* *} \\
(0.056)\end{array}$ & $\begin{array}{l}0.090 \\
(0.055)\end{array}$ & $\begin{array}{l}0.085 \\
(0.057)\end{array}$ \\
\hline Tail Event Dummy $\times$ High Availability Dummy & - & - & - & $\begin{array}{l}0.060 \\
(0.079)\end{array}$ \\
\hline High Availability Dummy & - & - & - & $\begin{array}{l}0.033 \\
(0.029)\end{array}$ \\
\hline Number of Tail Events & $\begin{array}{l}-0.012^{* *} \\
(0.005)\end{array}$ & $\begin{array}{c}-0.002 \\
(0.008)\end{array}$ & $\begin{array}{l}-0.020^{* * *} \\
(0.007)\end{array}$ & $\begin{array}{l}-0.012^{* *} \\
(0.005)\end{array}$ \\
\hline Constant & $\begin{array}{l}0.236^{* * *} \\
(0.056)\end{array}$ & $\begin{array}{l}0.212^{* * *} \\
(0.070)\end{array}$ & $\begin{array}{l}0.259^{* * *} \\
(0.072)\end{array}$ & $\begin{array}{l}0.215^{* * *} \\
(0.058)\end{array}$ \\
\hline Observations & 13,793 & 6,806 & 6,987 & 13,793 \\
\hline Number of Investors & 86 & 42 & 44 & 86 \\
\hline
\end{tabular}

${ }^{* * *} \mathrm{p}<0.01,{ }^{* *} \mathrm{p}<0.05,{ }^{*} \mathrm{p}<0.1$

The period variable had to be dropped for the estimation as time-dependent explanatory variables cannot be used with this estimation technique.

Table IV.1.5: Decrease in Bids, No Bankruptcy, Availability Bias and Tail Events. Panel probit regressions with random effects and robust standard errors clustered at the individual levels in parentheses, session fixed effects included.

\begin{tabular}{|c|c|c|c|c|}
\hline VARIABLE & & DOWN & UMMY & \\
\hline $\begin{array}{l}\text { SAMPLE } \\
\text { (Investors did not buy asset in previ- } \\
\text { ous period \& observed less than two tail } \\
\text { events) }\end{array}$ & (1) & $\begin{array}{l}(2) \\
\text { High } \\
\text { Availability Bias }\end{array}$ & $\begin{array}{l}\text { (3) } \\
\text { Low } \\
\text { Availability Bias }\end{array}$ & (4) \\
\hline Tail Event Dummy & $\begin{array}{l}0.395 \\
(0.246)\end{array}$ & $\begin{array}{l}0.462 \\
(0.318)\end{array}$ & $\begin{array}{l}0.302 \\
(0.395)\end{array}$ & $\begin{array}{l}0.274 \\
(0.381)\end{array}$ \\
\hline Tail Event $\times$ High Availability Dummy & - & - & - & $\begin{array}{l}0.212 \\
(0.489)\end{array}$ \\
\hline High Availability Dummy & - & - & - & $\begin{array}{l}0.099 \\
(0.136)\end{array}$ \\
\hline Period & $\begin{array}{l}-0.001^{\star *} \\
(0.000)\end{array}$ & $\begin{array}{l}-0.000 \\
(0.001)\end{array}$ & $\begin{array}{l}-0.002^{\text {}} \\
(0.001)\end{array}$ & $\begin{array}{l}-0.001^{\text {}} \\
(0.000)\end{array}$ \\
\hline Number of Tail Events & $\begin{array}{l}0.112^{* *} \\
(0.054)\end{array}$ & $\begin{array}{l}0.098 \\
(0.069)\end{array}$ & $\begin{array}{l}0.096 \\
(0.089)\end{array}$ & $\begin{array}{l}0.112^{* *} \\
(0.054)\end{array}$ \\
\hline Constant & $\begin{array}{l}-0.761^{* * *} \\
(0.236)\end{array}$ & $\begin{array}{l}-1.008^{* * *} \\
(0.335)\end{array}$ & $\begin{array}{l}-0.391^{* * *} \\
(0.118)\end{array}$ & $\begin{array}{l}-0.819^{* * *} \\
(0.257)\end{array}$ \\
\hline Observations & 9,769 & 4,865 & 4,904 & 9,769 \\
\hline Number of Investors & 86 & 42 & 44 & 86 \\
\hline
\end{tabular}

${ }^{* * *} \mathrm{p}<0.01,{ }^{* *} \mathrm{p}<0.05,{ }^{*} \mathrm{p}<0.1$ 


\section{IV.2 Hypothesis 2}

Table IV.2.1: Increase in Bids, Loss Aversion, Individual Controls and Tail Events. Panel probit regressions with random effects and robust standard errors clustered at the individual levels in parentheses, session fixed effects included.

\begin{tabular}{|c|c|c|c|c|}
\hline \multirow[t]{2}{*}{ VARIABLE } & \multicolumn{4}{|c|}{ UP DUMMY } \\
\hline & (1) & (2) & (3) & (4) \\
\hline SAMPLE & All & Low & High & All \\
\hline \multicolumn{2}{|l|}{ (Investors bought asset in previous period) } & Loss Aversion & \multicolumn{2}{|l|}{ Loss Aversion } \\
\hline \multirow[t]{2}{*}{ Tail Event Dummy } & $0.391^{\star *}$ & $0.603^{* *}$ & 0.176 & 0.208 \\
\hline & $(0.192)$ & $(0.285)$ & $(0.258)$ & $(0.260)$ \\
\hline \multirow[t]{2}{*}{ Tail Event $\times$ High Loss Aversion Dummy } & - & - & - & 0.326 \\
\hline & & & & $(0.374)$ \\
\hline \multirow[t]{2}{*}{ High Loss Aversion Dummy } & - & - & - & 0.053 \\
\hline & & & & $(0.244)$ \\
\hline \multirow[t]{2}{*}{ Stable Dummy } & $-0.001^{* * *}$ & -0.001 & $-0.002^{* * *}$ & $-0.001^{* * *}$ \\
\hline & $(0.000)$ & $(0.001)$ & $(0.001)$ & $(0.000)$ \\
\hline \multirow[t]{2}{*}{ Number of Tail Events } & 0.048 & 0.023 & 0.062 & 0.048 \\
\hline & $(0.043)$ & $(0.070)$ & $(0.057)$ & $(0.043)$ \\
\hline \multirow[t]{2}{*}{ Male (std) } & -0.059 & -0.022 & -0.082 & -0.059 \\
\hline & $(0.074)$ & $(0.077)$ & $(0.142)$ & $(0.073)$ \\
\hline \multirow[t]{2}{*}{ Availability Index (std) } & 0.085 & 0.031 & 0.202 & 0.084 \\
\hline & $(0.084)$ & $(0.101)$ & $(0.143)$ & $(0.084)$ \\
\hline \multirow[t]{2}{*}{ Loss Aversion (std) } & 0.094 & 0.119 & 0.061 & 0.073 \\
\hline & $(0.077)$ & $(0.111)$ & $(0.107)$ & $(0.122)$ \\
\hline \multirow[t]{2}{*}{ Risk Aversion (std) } & -0.076 & -0.027 & -0.025 & -0.079 \\
\hline & $(0.068)$ & $(0.148)$ & $(0.088)$ & $(0.069)$ \\
\hline \multirow[t]{2}{*}{ Ambiguity Aversion (std) } & -0.034 & -0.039 & 0.076 & -0.034 \\
\hline & $(0.034)$ & $(0.042)$ & $(0.079)$ & $(0.034)$ \\
\hline \multirow[t]{2}{*}{ Bayesian Updating Score (std) } & -0.019 & -0.080 & 0.011 & -0.014 \\
\hline & $(0.070)$ & $(0.065)$ & $(0.100)$ & $(0.075)$ \\
\hline \multirow[t]{2}{*}{ CRT score (std) } & $-0.130^{*}$ & $-0.241^{\star * *}$ & -0.061 & $-0.126^{*}$ \\
\hline & $(0.073)$ & $(0.090)$ & $(0.121)$ & $(0.076)$ \\
\hline \multirow[t]{2}{*}{ Emotionality Score (std) } & 0.088 & 0.032 & 0.017 & 0.089 \\
\hline & $(0.089)$ & $(0.116)$ & $(0.132)$ & $(0.090)$ \\
\hline \multirow[t]{2}{*}{ Prior Tail Events (std) } & 0.009 & -0.092 & $0.177^{* * *}$ & 0.009 \\
\hline & $(0.080)$ & $(0.147)$ & $(0.064)$ & $(0.080)$ \\
\hline \multirow[t]{2}{*}{ Constant } & $-1.018^{* * *}$ & $-0.892^{* * *}$ & $-1.593^{* *}$ & $-1.051^{* * *}$ \\
\hline & $(0.240)$ & $(0.218)$ & $(0.666)$ & $(0.325)$ \\
\hline Observations & 10,079 & 4,121 & 5,958 & 10,079 \\
\hline Number of investors & 85 & 36 & 49 & 85 \\
\hline
\end{tabular}

${ }^{* * *} \mathrm{p}<0.01,{ }^{* *} \mathrm{p}<0.05,{ }^{*} \mathrm{p}<0.1$ 
Table IV.2.2: Increase in Bids, Availability Bias, Autocorrelation and Tail Events. Panel linear regressions with AR(1) error terms and random effects and robust standard errors clustered at the individual levels in parentheses, session fixed effects included.

\begin{tabular}{|c|c|c|c|c|}
\hline VARIABLE & & & IMY & \\
\hline $\begin{array}{l}\text { SAMPLE } \\
\text { (Investors bought asset in previous period) }\end{array}$ & $(1)$ & $\begin{array}{l}(2) \\
\text { High } \\
\text { Loss Aversion }\end{array}$ & $\begin{array}{l}(3) \\
\text { Low } \\
\text { Loss Aversion }\end{array}$ & $(4)$ \\
\hline Tail Event Dummy & $\begin{array}{l}0.073 \\
(0.046)\end{array}$ & $\begin{array}{l}0.154^{* \star} \\
(0.072)\end{array}$ & $\begin{array}{l}-0.000 \\
(0.060)\end{array}$ & $\begin{array}{l}-0.009 \\
(0.067)\end{array}$ \\
\hline Tail Event Dummy $\times$ High Loss Aversion Dummy & - & - & - & $\begin{array}{l}0.156^{*} \\
(0.092)\end{array}$ \\
\hline High Loss Aversion Dummy & - & - & - & $\begin{array}{l}0.062^{* *} \\
(0.027)\end{array}$ \\
\hline Number of Tail Events & $\begin{array}{l}-0.012^{*} \\
(0.007)\end{array}$ & $\begin{array}{l}-0.008 \\
(0.011)\end{array}$ & $\begin{array}{c}-0.014 \\
(0.009)\end{array}$ & $\begin{array}{l}-0.012^{*} \\
(0.007)\end{array}$ \\
\hline Constant & $\begin{array}{l}0.211^{* * *} \\
(0.056)\end{array}$ & $\begin{array}{l}0.194^{* * *} \\
(0.054)\end{array}$ & $\begin{array}{l}0.231^{* * *} \\
(0.083)\end{array}$ & $\begin{array}{l}0.174^{* * *} \\
(0.057)\end{array}$ \\
\hline $\begin{array}{l}\text { Observations } \\
\text { Number of Investors }\end{array}$ & $\begin{array}{l}10,189 \\
86\end{array}$ & $\begin{array}{l}4,231 \\
37\end{array}$ & $\begin{array}{l}5,958 \\
49\end{array}$ & $\begin{array}{l}10,189 \\
86\end{array}$ \\
\hline
\end{tabular}

${ }^{* * *} \mathrm{p}<0.01,{ }^{* *} \mathrm{p}<0.05,{ }^{*} \mathrm{p}<0.1$

Table IV.2.3: Increase in Bids, No Bankruptcy, Loss Aversion and Tail Events. Panel probit regressions with random effects and robust standard errors clustered at the individual levels in parentheses, session fixed effects included.

\begin{tabular}{|c|c|c|c|c|}
\hline VARIABLE & & & $\overline{\mathrm{MMY}}$ & \\
\hline $\begin{array}{l}\text { SAMPLE } \\
\text { (Investors bought asset in previous period \& } \\
\text { observed less than two tail events) }\end{array}$ & (1) & $\begin{array}{l}(2) \\
\text { High } \\
\text { Loss Aversion }\end{array}$ & $\begin{array}{l}(3) \\
\text { Low } \\
\text { Loss Aversion }\end{array}$ & (4) \\
\hline Tail Event Dummy & $\begin{array}{l}0.210 \\
(0.215)\end{array}$ & $\begin{array}{l}0.378 \\
(0.294)\end{array}$ & $\begin{array}{l}0.055 \\
(0.324)\end{array}$ & $\begin{array}{l}0.027 \\
(0.336)\end{array}$ \\
\hline Tail Event $\times$ High Loss Aversion Dummy & - & - & - & $\begin{array}{l}0.336 \\
(0.435)\end{array}$ \\
\hline High Loss Aversion Dummy & - & - & - & $\begin{array}{l}0.209 \\
(0.146)\end{array}$ \\
\hline Period & $\begin{array}{l}-0.001 * * * \\
(0.001)\end{array}$ & $\begin{array}{l}-0.001 \\
(0.001)\end{array}$ & $\begin{array}{l}-0.002^{* *} \\
(0.001)\end{array}$ & $\begin{array}{l}-0.001^{* * *} \\
(0.001)\end{array}$ \\
\hline Number of Tail Events & $\begin{array}{l}0.087 \\
(0.065)\end{array}$ & $\begin{array}{l}0.058 \\
(0.094)\end{array}$ & $\begin{array}{l}0.109 \\
(0.096)\end{array}$ & $\begin{array}{l}0.087 \\
(0.065)\end{array}$ \\
\hline Constant & $\begin{array}{l}-0.873^{* * *} \\
(0.189)\end{array}$ & $\begin{array}{l}-1.030^{* * *} \\
(0.178)\end{array}$ & $\begin{array}{l}-0.620^{* *} \\
(0.293)\end{array}$ & $\begin{array}{l}-0.993^{* * *} \\
(0.237)\end{array}$ \\
\hline Observations & 7,873 & 3,202 & 4,671 & 7,873 \\
\hline Number of Investors & 86 & 37 & 49 & 86 \\
\hline
\end{tabular}

${ }^{* *} \mathrm{p}<0.01,{ }^{* *} \mathrm{p}<0.05,{ }^{*} \mathrm{p}<0.1$ 


\section{IV.3 Hypothesis 3}

Table IV.3.1: Increase in Bids, Tail Losses, Individual Controls, Emotional Arousal and Anger. Panel probit regressions with random effects and robust standard errors clustered at the individual levels in parentheses, session fixed effects included.

\begin{tabular}{|c|c|c|c|c|c|c|}
\hline VARIABLE & & & & MMY & & \\
\hline $\begin{array}{l}\text { SAMPLE } \\
\text { (PT investors who bought asset in } \\
\text { previous period \& observed less than } \\
\text { two tail events) }\end{array}$ & $\begin{array}{l}1) \\
\text { No feedback } \\
\text { arousal }\end{array}$ & $\begin{array}{l}(2) \\
\text { Feedback } \\
\text { arousal }\end{array}$ & (3) & $\begin{array}{l}(4) \\
\text { Anger- } \\
\text { prone }\end{array}$ & $\begin{array}{l}(5) \\
\text { Not anger- } \\
\text { prone }\end{array}$ & (6) \\
\hline Tail Event Dummy & $\begin{array}{l}-0.263 \\
(0.380)\end{array}$ & $\begin{array}{l}1.010^{* * *} \\
(0.364)\end{array}$ & $\begin{array}{l}-0.290 \\
(0.385)\end{array}$ & $\begin{array}{l}-6.495^{* * *} \\
(0.143)\end{array}$ & $\begin{array}{l}-0.085 \\
(0.430)\end{array}$ & $\begin{array}{l}-0.072 \\
(0.425)\end{array}$ \\
\hline Feedback Arousal Dummy & - & - & $\begin{array}{l}-0.076 \\
(0.058)\end{array}$ & $\begin{array}{l}0.042 \\
(0.082)\end{array}$ & $\begin{array}{l}-0.165^{\star *} \\
(0.075)\end{array}$ & $\begin{array}{l}-0.153^{* *} \\
(0.075)\end{array}$ \\
\hline $\begin{array}{l}\text { Tail Event } \times \text { Feedback Arousal } \\
\text { Dummy }\end{array}$ & - & - & $\begin{array}{l}1.512^{* *} \\
(0.617)\end{array}$ & $\begin{array}{l}12.903 \\
(0.000)\end{array}$ & $\begin{array}{l}1.032 \\
(0.750)\end{array}$ & $\begin{array}{l}1.017 \\
(0.751)\end{array}$ \\
\hline $\begin{array}{l}\text { Tail Event } \times \text { Feedback Arousal } \times \\
\text { Anger Dummy }\end{array}$ & - & - & - & - & - & $\begin{array}{l}6.167^{* * *} \\
(0.860)\end{array}$ \\
\hline Tail Event $\times$ Anger Dummy & - & - & - & - & - & $\begin{array}{l}-4.959^{* * *} \\
(0.462)\end{array}$ \\
\hline Feedback Arousal $\times$ Anger Dummy & - & - & - & - & - & $\begin{array}{l}0.190^{*} \\
(0.113)\end{array}$ \\
\hline Anger Dummy & - & - & - & - & - & $\begin{array}{l}-0.339 \\
(0.369)\end{array}$ \\
\hline Period & $\begin{array}{l}-0.000 \\
(0.001)\end{array}$ & $\begin{array}{l}-0.001 \\
(0.001)\end{array}$ & $\begin{array}{l}-0.001 \\
(0.001)\end{array}$ & $\begin{array}{l}-0.000 \\
(0.001)\end{array}$ & $\begin{array}{l}-0.001 \\
(0.001)\end{array}$ & $\begin{array}{l}-0.001 \\
(0.001)\end{array}$ \\
\hline Number of Tail Events & $\begin{array}{l}-0.062 \\
(0.074)\end{array}$ & $\begin{array}{l}0.163^{*} \\
(0.088)\end{array}$ & $\begin{array}{l}0.006 \\
(0.061)\end{array}$ & $\begin{array}{l}-0.009 \\
(0.066)\end{array}$ & $\begin{array}{l}0.013 \\
(0.095)\end{array}$ & $\begin{array}{l}0.003 \\
(0.061)\end{array}$ \\
\hline Male (std) & $\begin{array}{l}-0.125 \\
(0.112)\end{array}$ & $\begin{array}{l}-0.039 \\
(0.096)\end{array}$ & $\begin{array}{l}-0.123 \\
(0.109)\end{array}$ & $\begin{array}{l}17.267^{* * *} \\
(0.260)\end{array}$ & $\begin{array}{l}-0.310^{*} \\
(0.162)\end{array}$ & $\begin{array}{l}-0.134 \\
(0.113)\end{array}$ \\
\hline Availability Index (std) & $\begin{array}{l}-0.055 \\
(0.114)\end{array}$ & $\begin{array}{l}0.053 \\
(0.083)\end{array}$ & $\begin{array}{l}-0.047 \\
(0.109)\end{array}$ & $\begin{array}{l}-8.542^{* * *} \\
(0.135)\end{array}$ & $\begin{array}{l}-0.456^{* * *} \\
(0.159)\end{array}$ & $\begin{array}{l}-0.013 \\
(0.100)\end{array}$ \\
\hline Loss Aversion (std) & $\begin{array}{l}0.105 \\
(0.130)\end{array}$ & $\begin{array}{l}0.130 \\
(0.093)\end{array}$ & $\begin{array}{l}0.072 \\
(0.133)\end{array}$ & $\begin{array}{l}8.288^{* * *} \\
(0.118)\end{array}$ & $\begin{array}{l}-0.283 \\
(0.187)\end{array}$ & $\begin{array}{l}0.084 \\
(0.132)\end{array}$ \\
\hline Risk Aversion (std) & $\begin{array}{l}-0.094 \\
(0.131)\end{array}$ & $\begin{array}{l}-0.156 \\
(0.138)\end{array}$ & $\begin{array}{l}-0.140 \\
(0.121)\end{array}$ & $\begin{array}{l}4.986^{* * *} \\
(0.072)\end{array}$ & $\begin{array}{l}-0.141 \\
(0.161)\end{array}$ & $\begin{array}{l}-0.170 \\
(0.122)\end{array}$ \\
\hline Ambiguity Aversion (std) & $\begin{array}{l}-0.036 \\
(0.037)\end{array}$ & $\begin{array}{l}0.005 \\
(0.030)\end{array}$ & $\begin{array}{l}-0.038 \\
(0.037)\end{array}$ & $\begin{array}{l}0.631^{* * *} \\
(0.013)\end{array}$ & $\begin{array}{l}-0.050 \\
(0.041)\end{array}$ & $\begin{array}{l}-0.032 \\
(0.036)\end{array}$ \\
\hline $\begin{array}{l}\text { Bayesian Updating Score } \\
\text { (std) }\end{array}$ & $\begin{array}{l}-0.016 \\
(0.101)\end{array}$ & $\begin{array}{l}-0.160^{*} \\
(0.090)\end{array}$ & $\begin{array}{l}-0.056 \\
(0.093)\end{array}$ & $\begin{array}{l}12.894^{* * *} \\
(0.198)\end{array}$ & $\begin{array}{l}-0.163 \\
(0.126)\end{array}$ & $\begin{array}{l}-0.140 \\
(0.145)\end{array}$ \\
\hline CRT score $($ std) & $\begin{array}{l}0.014 \\
(0.096)\end{array}$ & $\begin{array}{l}-0.113^{* *} \\
(0.057)\end{array}$ & $\begin{array}{l}-0.007 \\
(0.093)\end{array}$ & $\begin{array}{l}-3.133^{* * *} \\
(0.053)\end{array}$ & $\begin{array}{l}0.048 \\
(0.112)\end{array}$ & $\begin{array}{l}-0.054 \\
(0.110)\end{array}$ \\
\hline Emotionality Score (std) & $\begin{array}{l}0.210 \\
(0.145)\end{array}$ & $\begin{array}{l}0.176 \\
(0.108)\end{array}$ & $\begin{array}{l}0.190 \\
(0.142)\end{array}$ & - & $\begin{array}{l}0.254^{*} \\
(0.130)\end{array}$ & $\begin{array}{l}0.217 \\
(0.150)\end{array}$ \\
\hline Prior Tail Events (std) & $\begin{array}{l}-0.176 \\
(0.157)\end{array}$ & $\begin{array}{l}-0.144 \\
(0.111)\end{array}$ & $\begin{array}{l}-0.117 \\
(0.150)\end{array}$ & - & $\begin{array}{l}-0.018 \\
(0.159)\end{array}$ & $\begin{array}{l}-0.166 \\
(0.168)\end{array}$ \\
\hline Constant & $\begin{array}{l}-0.982^{* * *} \\
(0.227)\end{array}$ & $\begin{array}{l}-1.080^{* * *} \\
(0.369)\end{array}$ & $\begin{array}{l}-0.995^{\star * *} \\
(0.218)\end{array}$ & $\begin{array}{l}-7.321^{* * *} \\
(0.143)\end{array}$ & $\begin{array}{l}-1.608^{* * *} \\
(0.330)\end{array}$ & $\begin{array}{l}-0.887^{* * *} \\
(0.228)\end{array}$ \\
\hline Observations & 3,727 & 1,272 & 4,999 & 1,961 & 2,871 & 4,999 \\
\hline Number of investors & 43 & 43 & 43 & 16 & 26 & 43 \\
\hline
\end{tabular}

${ }^{* * *} \mathrm{p}<0.01,{ }^{* *} \mathrm{p}<0.05,{ }^{*} \mathrm{p}<0.1$ 
Table IV.3.2: Increase in Bids, Tail Losses, Autocorrelation, Emotional Arousal and Anger. Panel linear regressions with AR(1) error terms and random effects and robust standard errors clustered at the individual levels in parentheses, session fixed effects included.

\begin{tabular}{|c|c|c|c|c|c|c|}
\hline VARIABLE & & & & MMY & & \\
\hline $\begin{array}{l}\text { SAMPLE } \\
\text { (PT investors who bought asset in } \\
\text { previous period) }\end{array}$ & $\begin{array}{l}\text { (1) } \\
\text { No feedback } \\
\text { arousal }\end{array}$ & $\begin{array}{l}(2) \\
\text { Feedback } \\
\text { arousal }\end{array}$ & (3) & $\begin{array}{l}\text { (4) } \\
\text { Anger- } \\
\text { prone }\end{array}$ & $\begin{array}{l}\text { (5) } \\
\text { Not anger- } \\
\text { prone }\end{array}$ & (6) \\
\hline Tail Event Dummy & $\begin{array}{l}-0.102 \\
(0.099)\end{array}$ & $\begin{array}{l}0.338^{* * *} \\
(0.102)\end{array}$ & $\begin{array}{l}-0.122 \\
(0.099)\end{array}$ & $\begin{array}{l}-0.207 \\
(0.194)\end{array}$ & $\begin{array}{l}-0.099 \\
(0.114)\end{array}$ & $\begin{array}{l}-0.092 \\
(0.115)\end{array}$ \\
\hline Feedback Arousal Dummy & - & - & $\begin{array}{l}-0.015 \\
(0.015)\end{array}$ & $\begin{array}{l}0.026 \\
(0.025)\end{array}$ & $\begin{array}{l}-0.039^{* *} \\
(0.019)\end{array}$ & $\begin{array}{l}-0.041^{\star *} \\
(0.019)\end{array}$ \\
\hline $\begin{array}{l}\text { Tail Event } \times \text { Feedback Arousal } \\
\text { Dummy }\end{array}$ & - & - & $\begin{array}{l}0.545^{* * *} \\
(0.139)\end{array}$ & $\begin{array}{l}0.846^{* * *} \\
(0.254)\end{array}$ & $\begin{array}{l}0.390^{* *} \\
(0.167)\end{array}$ & $\begin{array}{l}0.383^{\star *} \\
(0.169)\end{array}$ \\
\hline $\begin{array}{l}\text { Tail Event } \times \text { Feedback Arousal } \times \\
\text { Anger Dummy }\end{array}$ & - & - & - & - & - & $\begin{array}{l}0.467 \\
(0.300)\end{array}$ \\
\hline Tail Event $\times$ Anger Dummy & - & - & - & - & - & $\begin{array}{l}-0.117 \\
(0.222)\end{array}$ \\
\hline Feedback Arousal $\times$ Anger Dummy & - & - & - & - & - & $\begin{array}{l}0.070^{* *} \\
(0.031)\end{array}$ \\
\hline Anger Dummy & - & - & - & - & - & $\begin{array}{l}0.007 \\
(0.044)\end{array}$ \\
\hline Number of Tail Events & $\begin{array}{l}-0.021 \\
(0.013)\end{array}$ & $\begin{array}{l}0.016 \\
(0.024)\end{array}$ & $\begin{array}{l}-0.011 \\
(0.011)\end{array}$ & $\begin{array}{l}-0.007 \\
(0.021)\end{array}$ & $\begin{array}{l}-0.012 \\
(0.012)\end{array}$ & $\begin{array}{l}-0.011 \\
(0.011)\end{array}$ \\
\hline Constant & $\begin{array}{l}0.214^{* * *} \\
(0.065)\end{array}$ & $\begin{array}{l}0.152^{*} \\
(0.088)\end{array}$ & $\begin{array}{l}0.202^{* * *} \\
(0.063)\end{array}$ & $\begin{array}{l}0.186^{*} \\
(0.109)\end{array}$ & $\begin{array}{l}0.212^{* * *} \\
(0.067)\end{array}$ & $\begin{array}{l}0.202^{* * *} \\
(0.063)\end{array}$ \\
\hline Observations & 3,832 & 1,277 & 5,109 & 1,961 & 3,148 & 5,109 \\
\hline Number of Investors & 44 & 44 & 44 & 16 & 28 & 44 \\
\hline
\end{tabular}

${ }^{* * *} \mathrm{p}<0.01,{ }^{* *} \mathrm{p}<0.05,{ }^{*} \mathrm{p}<0.1$

Table IV.3.3: Increase in Bids, Tail Losses, No Bankruptcy, Emotional Arousal and Anger. Panel probit regressions with random effects and robust standard errors clustered at the individual levels in parentheses, session fixed effects included.

\begin{tabular}{|c|c|c|c|c|c|}
\hline \multirow[b]{2}{*}{$\begin{array}{l}\text { VARIABLE } \\
\text { SAMPLE } \\
\text { (PT investors who bought asset in previous } \\
\text { period \& observed less than two tail events) }\end{array}$} & \multicolumn{5}{|c|}{ UP DUMMY } \\
\hline & $\begin{array}{l}(1) \\
\text { No feedback } \\
\text { arousal }\end{array}$ & $\begin{array}{l}(2) \\
\text { Feedback } \\
\text { arousal }\end{array}$ & (3) & $\begin{array}{l}4) \\
\text { Anger- } \\
\text { prone }\end{array}$ & $\begin{array}{l}(5) \\
\text { Not anger- } \\
\text { prone }\end{array}$ \\
\hline Tail Event Dummy & $\begin{array}{l}0.063 \\
(0.364)\end{array}$ & $\begin{array}{l}0.794^{*} \\
(0.418)\end{array}$ & $\begin{array}{l}0.032 \\
(0.365)\end{array}$ & $\begin{array}{l}-4.529^{* * *} \\
(0.200)\end{array}$ & $\begin{array}{l}0.196 \\
(0.411)\end{array}$ \\
\hline Feedback Arousal Dummy & - & - & $\begin{array}{l}-0.128^{*} \\
(0.066)\end{array}$ & $\begin{array}{l}0.012 \\
(0.070)\end{array}$ & $\begin{array}{l}-0.253^{* * *} \\
(0.092)\end{array}$ \\
\hline Tail Event $\times$ Feedback Arousal Dummy & - & - & $\begin{array}{l}1.045^{*} \\
(0.572)\end{array}$ & $\begin{array}{l}6.299^{* * *} \\
(0.411)\end{array}$ & $\begin{array}{l}0.597 \\
(0.707)\end{array}$ \\
\hline Period & $\begin{array}{l}-0.000 \\
(0.001)\end{array}$ & $\begin{array}{l}-0.001 \\
(0.001)\end{array}$ & $\begin{array}{l}-0.001 \\
(0.001)\end{array}$ & $\begin{array}{l}-0.001 \\
(0.001)\end{array}$ & $\begin{array}{l}-0.001 \\
(0.001)\end{array}$ \\
\hline Number of Tail Events & $\begin{array}{l}-0.038 \\
(0.101)\end{array}$ & $\begin{array}{l}0.192 \\
(0.132)\end{array}$ & $\begin{array}{l}0.040 \\
(0.079)\end{array}$ & $\begin{array}{l}-0.051 \\
(0.100)\end{array}$ & $\begin{array}{l}0.087 \\
(0.140)\end{array}$ \\
\hline Constant & $\begin{array}{l}-1.070^{* * *} \\
(0.172)\end{array}$ & $\begin{array}{l}-0.828^{* * *} \\
(0.302)\end{array}$ & $\begin{array}{l}-1.018^{* * *} \\
(0.186)\end{array}$ & $\begin{array}{l}-1.541^{* * *} \\
(0.019)\end{array}$ & $\begin{array}{l}-0.782^{* * *} \\
(0.028)\end{array}$ \\
\hline Observations & 3,002 & 983 & 3,985 & 1,713 & 2,105 \\
\hline Number of Investors & 44 & 44 & 44 & 16 & 27 \\
\hline
\end{tabular}

${ }^{* *} \mathrm{p}<0.01,{ }^{* *} \mathrm{p}<0.05,{ }^{*} \mathrm{p}<0.1$

The equivalent of regression (6) in Table 3 could not be estimated because of insufficient data. 


\section{IV.4 Hypothesis 4}

\section{IV.4.1 Hypothesis $4 \mathrm{i}$}

Table IV.4.1: Decrease in Bids, Tail Losses, Individual Controls, Hope and Fear. Panel probit regressions with random effects and robust standard errors clustered at the individual levels in parentheses, session fixed effects included.

\begin{tabular}{|c|c|c|c|c|}
\hline \multirow[t]{2}{*}{ VARIABLE } & \multicolumn{4}{|c|}{ DOWN DUMMY } \\
\hline & (1) & (2) & (3) & (4) \\
\hline \multirow{2}{*}{$\begin{array}{l}\text { SAMPLE } \\
\text { (Investors did not buy asset in previous period) }\end{array}$} & Hopeful \& & \multirow{2}{*}{\multicolumn{2}{|c|}{$\begin{array}{l}\text { Fearful \& } \\
\text { Not Hopeful }\end{array}$}} & High Availabil- \\
\hline & Not fearful & & & ity Bias \\
\hline \multirow{2}{*}{ Tail Event Dummy } & $0.605^{*}$ & 0.296 & 0.257 & 0.180 \\
\hline & $(0.363)$ & $(0.339)$ & $(0.339)$ & $(0.509)$ \\
\hline \multirow[t]{2}{*}{ Hopeful Dummy } & - & - & -0.196 & $1.759^{* * *}$ \\
\hline & & & $(0.238)$ & $(0.560)$ \\
\hline \multirow[t]{2}{*}{ Feedback Arousal Dummy } & 0.068 & 0.042 & 0.018 & -0.072 \\
\hline & $(0.072)$ & $(0.068)$ & $(0.068)$ & $(0.103)$ \\
\hline \multirow[t]{2}{*}{ Tail Event $\times$ Feedback Arousal Dummy } & $-0.834^{*}$ & 0.349 & 0.347 & 1.253 \\
\hline & $(0.486)$ & $(0.568)$ & $(0.563)$ & $(0.775)$ \\
\hline \multirow[t]{2}{*}{ Tail Event $\times$ Hopeful Dummy } & - & - & 0.359 & 0.609 \\
\hline & & & $(0.482)$ & $(0.617)$ \\
\hline \multirow[t]{2}{*}{ Feedback Arousal $\times$ Hopeful Dummy } & - & - & 0.055 & 0.161 \\
\hline & & & $(0.097)$ & $(0.145)$ \\
\hline \multirow[t]{2}{*}{ Tail Event $\times$ Feedback Arousal $\times$ Hopeful Dummy } & - & - & -1.184 & $-2.380^{* *}$ \\
\hline & & & $(0.732)$ & $(0.933)$ \\
\hline \multirow[t]{2}{*}{ Period } & $-0.002^{\star}$ & 0.000 & -0.001 & -0.000 \\
\hline & $(0.001)$ & $(0.001)$ & $(0.001)$ & $(0.001)$ \\
\hline \multirow[t]{2}{*}{ Number of Tail Events } & 0.050 & -0.076 & -0.015 & -0.053 \\
\hline & $(0.067)$ & $(0.065)$ & $(0.048)$ & $(0.064)$ \\
\hline \multirow[t]{2}{*}{ Male (std) } & -0.050 & $0.526^{* * *}$ & 0.019 & 0.008 \\
\hline & $(0.180)$ & $(0.049)$ & $(0.110)$ & $(0.118)$ \\
\hline \multirow[t]{2}{*}{ Availability Index (std) } & 0.243 & $-0.606^{* * *}$ & 0.047 & $1.059^{* * *}$ \\
\hline & $(0.246)$ & $(0.063)$ & $(0.101)$ & $(0.306)$ \\
\hline \multirow[t]{2}{*}{ Loss Aversion (std) } & -0.035 & $0.171^{\star * *}$ & 0.111 & -0.039 \\
\hline & $(0.286)$ & $(0.035)$ & $(0.133)$ & $(0.148)$ \\
\hline \multirow[t]{2}{*}{ Risk Aversion (std) } & 0.022 & $-1.903^{* * *}$ & -0.081 & $0.256^{* *}$ \\
\hline & $(0.273)$ & $(0.133)$ & $(0.105)$ & $(0.129)$ \\
\hline \multirow[t]{2}{*}{ Ambiguity Aversion (std) } & 0.053 & $-1.043^{* * *}$ & -0.059 & -0.111 \\
\hline & $(0.153)$ & $(0.057)$ & $(0.041)$ & $(0.068)$ \\
\hline \multirow[t]{2}{*}{ Bayesian Updating Score (std) } & -0.061 & $1.710^{* * *}$ & 0.031 & $0.575^{* *}$ \\
\hline & $(0.290)$ & $(0.102)$ & $(0.099)$ & $(0.248)$ \\
\hline \multirow[t]{2}{*}{ CRT score (std) } & -0.026 & $-1.138^{* * *}$ & $-0.260^{* *}$ & $0.403^{* *}$ \\
\hline & $(0.214)$ & $(0.046)$ & $(0.103)$ & $(0.178)$ \\
\hline \multirow[t]{2}{*}{ Emotionality Score (std) } & 0.106 & $2.615^{* * *}$ & -0.008 & $0.830^{* * *}$ \\
\hline & $(0.196)$ & $(0.218)$ & $(0.139)$ & $(0.247)$ \\
\hline \multirow[t]{2}{*}{ Prior Tail Events (std) } & 0.140 & $1.516^{* * *}$ & -0.066 & $0.252^{* * *}$ \\
\hline & $(0.192)$ & $(0.107)$ & $(0.074)$ & $(0.081)$ \\
\hline \multirow[t]{2}{*}{ Constant } & $-1.342^{* * *}$ & $-2.665^{* * *}$ & $-0.452^{* * *}$ & $-2.048^{* * *}$ \\
\hline & $(0.395)$ & $(0.190)$ & $(0.151)$ & $(0.428)$ \\
\hline Observations & 4,959 & 3,494 & 8,453 & 4,623 \\
\hline Number of investors & 29 & 21 & 50 & 28 \\
\hline
\end{tabular}

${ }^{* * *} \mathrm{p}<0.01,{ }^{* *} \mathrm{p}<0.05,{ }^{*} \mathrm{p}<0.1$ 
Table IV.4.2: Decrease in Bids, Tail Losses, Autocorrelation, Hope and Fear. Panel linear regressions with AR(1) error terms and random effects and robust standard errors clustered at the individual levels in parentheses, session fixed effects included.

\begin{tabular}{|c|c|c|c|c|}
\hline \multirow[t]{2}{*}{ VARIABLE } & \multicolumn{4}{|c|}{ DOWN DUMMY } \\
\hline & (1) & (2) & (3) & (4) \\
\hline \multirow{2}{*}{$\begin{array}{l}\text { SAMPLE } \\
\text { (Investors did not buy asset in previous period) }\end{array}$} & Hopeful \& & \multirow{2}{*}{\multicolumn{2}{|c|}{$\begin{array}{l}\text { Fearful \& } \\
\text { Not Hopeful }\end{array}$}} & High Availabil- \\
\hline & Not fearful & & & ity Bias \\
\hline \multirow{2}{*}{ Tail Event Dummy } & $0.223^{*}$ & 0.118 & 0.117 & 0.050 \\
\hline & $(0.124)$ & $(0.111)$ & $(0.107)$ & $(0.152)$ \\
\hline \multirow[t]{2}{*}{ Hopeful Dummy } & - & - & -0.046 & -0.068 \\
\hline & & & $(0.045)$ & $(0.053)$ \\
\hline \multirow[t]{2}{*}{ Feedback Arousal Dummy } & 0.015 & -0.002 & -0.001 & -0.036 \\
\hline & $(0.014)$ & $(0.017)$ & $(0.017)$ & $(0.024)$ \\
\hline \multirow[t]{2}{*}{ Tail Event $\times$ Feedback Arousal Dummy } & $-0.247^{*}$ & 0.171 & 0.173 & $0.480^{* *}$ \\
\hline & $(0.147)$ & $(0.178)$ & $(0.171)$ & $(0.223)$ \\
\hline \multirow[t]{2}{*}{ Tail Event $\times$ Hopeful Dummy } & - & - & 0.104 & 0.248 \\
\hline & & & $(0.166)$ & $(0.202)$ \\
\hline \multirow[t]{2}{*}{ Feedback Arousal $\times$ Hopeful Dummy } & - & - & 0.017 & $0.061^{*}$ \\
\hline & & & $(0.022)$ & $(0.031)$ \\
\hline \multirow[t]{2}{*}{ Tail Event $\times$ Feedback Arousal $\times$ Hopeful Dummy } & - & - & $-0.420^{*}$ & $-0.820^{* * *}$ \\
\hline & & & $(0.228)$ & $(0.278)$ \\
\hline \multirow[t]{2}{*}{ Number of Tail Events } & $-0.017^{*}$ & -0.013 & $-0.015^{* *}$ & -0.016 \\
\hline & $(0.009)$ & $(0.012)$ & $(0.007)$ & $(0.010)$ \\
\hline \multirow[t]{2}{*}{ Constant } & 0.143 & $0.303^{* * *}$ & $0.307^{* * *}$ & $0.340^{* * *}$ \\
\hline & $(0.118)$ & $(0.059)$ & $(0.069)$ & $(0.067)$ \\
\hline Observations & 4,959 & 3,494 & 8,453 & 4,623 \\
\hline Number of investors & 29 & 21 & 50 & 28 \\
\hline
\end{tabular}

${ }^{* * *} \mathrm{p}<0.01,{ }^{* *} \mathrm{p}<0.05,{ }^{*} \mathrm{p}<0.1$ 
Table IV.4.3: Decrease in Bids, Tail Losses, No Bankruptcy, Hope and Fear. Panel probit regressions with random effects and robust standard errors clustered at the individual levels in parentheses, session fixed effects included.

\begin{tabular}{|c|c|c|c|c|}
\hline \multirow{4}{*}{$\begin{array}{l}\text { VARIABLE } \\
\text { SAMPLE } \\
\text { (Investors did not buy asset in previous period \& } \\
\text { observed less than two tail events) }\end{array}$} & \multicolumn{4}{|c|}{ DOWN DUMMY } \\
\hline & (1) & (2) & (3) & (4) \\
\hline & Hopeful \& & Fearful \& & & High Availabil- \\
\hline & Not fearful & Not Hopeful & & ity Bias \\
\hline \multirow{2}{*}{ Tail Event Dummy } & 0.619 & $-5.381^{* * *}$ & $-4.832^{* * *}$ & $-4.761^{* * *}$ \\
\hline & $(0.687)$ & $(0.169)$ & $(0.160)$ & $(0.244)$ \\
\hline \multirow[t]{2}{*}{ Hopeful Dummy } & - & - & -0.197 & -0.404 \\
\hline & & & $(0.209)$ & $(0.267)$ \\
\hline \multirow[t]{2}{*}{ Feedback Arousal Dummy } & -0.038 & 0.029 & 0.006 & -0.078 \\
\hline & $(0.073)$ & $(0.081)$ & $(0.083)$ & $(0.134)$ \\
\hline \multirow[t]{2}{*}{ Tail Event $\times$ Feedback Arousal Dummy } & -0.356 & $6.048^{* * *}$ & $5.488^{* * *}$ & $5.919^{* * *}$ \\
\hline & $(0.853)$ & $(0.591)$ & $(0.590)$ & $(0.729)$ \\
\hline \multirow[t]{2}{*}{ Tail Event $\times$ Hopeful Dummy } & - & - & $5.450^{* * *}$ & $5.385^{* * *}$ \\
\hline & & & $(0.679)$ & $(0.707)$ \\
\hline \multirow[t]{2}{*}{ Feedback Arousal $\times$ Hopeful Dummy } & - & - & -0.035 & -0.005 \\
\hline & & & $(0.107)$ & $(0.165)$ \\
\hline \multirow[t]{2}{*}{ Tail Event $\times$ Feedback Arousal $\times$ Hopeful Dummy } & - & - & $-5.865^{\star * *}$ & $-6.417^{* * *}$ \\
\hline & & & $(1.021)$ & $(1.282)$ \\
\hline \multirow[t]{2}{*}{ Period } & $-0.002^{*}$ & 0.000 & -0.001 & -0.000 \\
\hline & $(0.001)$ & $(0.001)$ & $(0.001)$ & $(0.001)$ \\
\hline \multirow[t]{2}{*}{ Number of Tail Events } & $0.171^{\star}$ & 0.038 & 0.106 & 0.077 \\
\hline & $(0.092)$ & $(0.098)$ & $(0.067)$ & $(0.100)$ \\
\hline \multirow[t]{2}{*}{ Constant } & $-0.771^{\star * *}$ & $-0.587^{* * *}$ & $-0.576^{* * *}$ & $-0.597^{* * *}$ \\
\hline & $(0.044)$ & $(0.138)$ & $(0.137)$ & $(0.209)$ \\
\hline Observations & 3,713 & 2,402 & 6,115 & 3,217 \\
\hline Number of investors & 29 & 21 & 50 & 28 \\
\hline
\end{tabular}

${ }^{* * *} \mathrm{p}<0.01,{ }^{* *} \mathrm{p}<0.05,{ }^{*} \mathrm{p}<0.1$ 
Table IV.4.4: Decrease in Bids, Hope and Emotionality. Panel probit regressions with random effects and robust standard errors clustered at the individual levels in parentheses, session fixed effects included. Emotional (not emotional) investors are those who score above (below) the median on the HEXACO emotionality factor.

\begin{tabular}{|c|c|c|c|c|}
\hline \multirow[b]{2}{*}{$\begin{array}{l}\text { VARIABLE } \\
\text { SAMPLE } \\
\text { (Investors bought asset in previous period \& ob- } \\
\text { served less than two tail events) }\end{array}$} & \multicolumn{4}{|c|}{ DOWN DUMMY } \\
\hline & $\begin{array}{l}\text { (1) } \\
\text { Hopeful \& Not } \\
\text { emotional }\end{array}$ & $\begin{array}{l}\text { (2) } \\
\text { Emotional } \\
\text { Not Hopeful }\end{array}$ & $(3)$ & $\begin{array}{l}(4) \\
\text { High Availabil- } \\
\text { ity Bias }\end{array}$ \\
\hline Tail Event Dummy & $\begin{array}{l}0.789^{*} \\
(0.409)\end{array}$ & $\begin{array}{l}0.515 \\
(0.329)\end{array}$ & $\begin{array}{l}0.455 \\
(0.339)\end{array}$ & $\begin{array}{l}0.574 \\
(0.543)\end{array}$ \\
\hline Hopeful Dummy & - & - & $\begin{array}{l}-0.135 \\
(0.204)\end{array}$ & $\begin{array}{l}-0.521^{*} \\
(0.303)\end{array}$ \\
\hline Feedback Arousal Dummy & $\begin{array}{l}0.032 \\
(0.073)\end{array}$ & $\begin{array}{l}0.036 \\
(0.073)\end{array}$ & $\begin{array}{l}0.015 \\
(0.068)\end{array}$ & $\begin{array}{l}-0.026 \\
(0.073)\end{array}$ \\
\hline Tail Event $\times$ Feedback Arousal Dummy & $\begin{array}{l}-0.658 \\
(0.499)\end{array}$ & $\begin{array}{l}0.303 \\
(0.623)\end{array}$ & $\begin{array}{l}0.324 \\
(0.608)\end{array}$ & $\begin{array}{l}6.226^{* * *} \\
(0.583)\end{array}$ \\
\hline Tail Event $\times$ Hopeful Dummy & - & - & $\begin{array}{l}0.329 \\
(0.519)\end{array}$ & $\begin{array}{l}0.522 \\
(0.705)\end{array}$ \\
\hline Feedback Arousal $\times$ Hopeful Dummy & - & - & $\begin{array}{l}0.024 \\
(0.097)\end{array}$ & $\begin{array}{l}0.104 \\
(0.144)\end{array}$ \\
\hline Tail Event $\times$ Feedback Arousal $\times$ Hopeful Dummy & - & - & $\begin{array}{l}-0.974 \\
(0.777)\end{array}$ & $\begin{array}{l}-7.131^{* * *} \\
(0.835)\end{array}$ \\
\hline Period & $\begin{array}{l}-0.002^{\star *} \\
(0.001)\end{array}$ & $\begin{array}{l}0.001^{*} \\
(0.001)\end{array}$ & $\begin{array}{l}-0.000 \\
(0.001)\end{array}$ & $\begin{array}{l}-0.000 \\
(0.001)\end{array}$ \\
\hline Number of Tail Events & $\begin{array}{l}0.072 \\
(0.065)\end{array}$ & $\begin{array}{l}-0.096 \\
(0.063)\end{array}$ & $\begin{array}{l}-0.011 \\
(0.047)\end{array}$ & $\begin{array}{l}0.002 \\
(0.066)\end{array}$ \\
\hline Constant & $\begin{array}{l}-0.312^{* * *} \\
(0.044)\end{array}$ & $\begin{array}{l}-0.571^{* * *} \\
(0.154)\end{array}$ & $\begin{array}{l}-0.492^{* * *} \\
(0.131)\end{array}$ & $\begin{array}{l}-0.493^{* * *} \\
(0.177) \\
\end{array}$ \\
\hline Observations & 5,188 & 3,086 & 8,274 & 4,337 \\
\hline Number of investors & 30 & 19 & 49 & 26 \\
\hline
\end{tabular}




\section{IV.4.2 Hypothesis 4ii}

Table IV.4.5: Decrease in Bids, Tail Losses, Individual Controls, Hope and Fear. Panel probit regressions with random effects and robust standard errors clustered at the individual levels in parentheses, session fixed effects included.

\begin{tabular}{|c|c|c|c|}
\hline VARIABLE & & UP DUMM & \\
\hline $\begin{array}{l}\text { SAMPLE } \\
\text { (Investors bought asset in previous pe- } \\
\text { riod) }\end{array}$ & $\begin{array}{l}\text { (1) } \\
\text { Hopeful } \\
\text { \& Not fearful }\end{array}$ & $\begin{array}{l}\text { (2) } \\
\text { Fearful } \\
\text { \& Not Hopeful }\end{array}$ & (3) \\
\hline Tail Event Dummy & $\begin{array}{l}-5.244^{* * *} \\
(0.145)\end{array}$ & $\begin{array}{l}-0.209 \\
(0.619)\end{array}$ & $\begin{array}{l}-0.242 \\
(0.638)\end{array}$ \\
\hline Hopeful Dummy & - & - & $\begin{array}{l}-0.249 \\
(0.273)\end{array}$ \\
\hline Feedback Arousal Dummy & $\begin{array}{l}-0.122 \\
(0.095)\end{array}$ & $\begin{array}{l}0.064 \\
(0.060)\end{array}$ & $\begin{array}{l}0.015 \\
(0.061)\end{array}$ \\
\hline Tail Event $\times$ Feedback Arousal Dummy & $\begin{array}{l}5.703^{* * *} \\
(0.532)\end{array}$ & $\begin{array}{l}0.083 \\
(0.992)\end{array}$ & $\begin{array}{l}0.159 \\
(0.961)\end{array}$ \\
\hline Tail Event $\times$ Hopeful Dummy & - & - & $\begin{array}{l}-4.982^{* * *} \\
(0.656)\end{array}$ \\
\hline Feedback Arousal $\times$ Hopeful Dummy & - & - & $\begin{array}{l}-0.122 \\
(0.110)\end{array}$ \\
\hline $\begin{array}{l}\text { Tail Event } \times \text { Feedback Arousal } \times \text { Hope- } \\
\text { ful Dummy }\end{array}$ & - & - & $\begin{array}{l}5.556^{* * *} \\
(1.098)\end{array}$ \\
\hline Period & $\begin{array}{l}-0.002 \\
(0.001)\end{array}$ & $\begin{array}{l}-0.000 \\
(0.001)\end{array}$ & $\begin{array}{l}-0.001 \\
(0.001)\end{array}$ \\
\hline Number of Tail Events & $\begin{array}{l}0.090 \\
(0.129)\end{array}$ & $\begin{array}{l}0.005 \\
(0.096)\end{array}$ & $\begin{array}{l}0.036 \\
(0.079)\end{array}$ \\
\hline Male (std) & $\begin{array}{l}0.008 \\
(0.169)\end{array}$ & $\begin{array}{l}0.143^{* *} \\
(0.064)\end{array}$ & $\begin{array}{l}0.004 \\
(0.130)\end{array}$ \\
\hline Availability Index (std) & $\begin{array}{l}0.146 \\
(0.224)\end{array}$ & $\begin{array}{l}-0.211^{*} \\
(0.114)\end{array}$ & $\begin{array}{l}0.053 \\
(0.114)\end{array}$ \\
\hline Loss Aversion (std) & $\begin{array}{l}0.059 \\
(0.292)\end{array}$ & $\begin{array}{l}-0.427^{* * *} \\
(0.127)\end{array}$ & $\begin{array}{l}0.070 \\
(0.136)\end{array}$ \\
\hline Risk Aversion (std) & $\begin{array}{l}-0.005 \\
(0.259)\end{array}$ & $\begin{array}{l}-0.866^{* * *} \\
(0.203)\end{array}$ & $\begin{array}{l}-0.185 \\
(0.133)\end{array}$ \\
\hline Ambiguity Aversion (std) & $\begin{array}{l}0.019 \\
(0.146)\end{array}$ & $\begin{array}{l}-0.420^{* * *} \\
(0.065)\end{array}$ & $\begin{array}{l}-0.083^{*} \\
(0.047)\end{array}$ \\
\hline Bayesian Updating Score (std) & $\begin{array}{l}-0.108 \\
(0.294)\end{array}$ & $\begin{array}{l}0.708^{* * *} \\
(0.136)\end{array}$ & $\begin{array}{l}-0.006 \\
(0.121)\end{array}$ \\
\hline CRT score (std) & $\begin{array}{l}-0.004 \\
(0.214)\end{array}$ & $\begin{array}{l}-0.640^{* * *} \\
(0.061)\end{array}$ & $\begin{array}{l}-0.252^{* *} \\
(0.113)\end{array}$ \\
\hline Emotionality Score (std) & $\begin{array}{l}0.137 \\
(0.199)\end{array}$ & $\begin{array}{l}0.780^{* * *} \\
(0.169)\end{array}$ & $\begin{array}{l}-0.036 \\
(0.142)\end{array}$ \\
\hline Prior Tail Events (std) & $\begin{array}{l}0.061 \\
(0.193)\end{array}$ & $\begin{array}{l}0.317 \\
(0.207)\end{array}$ & $\begin{array}{l}-0.010 \\
(0.080)\end{array}$ \\
\hline Constant & $\begin{array}{l}-0.832^{*} \\
(0.446)\end{array}$ & $\begin{array}{l}-1.422^{* * *} \\
(0.224)\end{array}$ & $\begin{array}{l}-0.819^{* * *} \\
(0.291)\end{array}$ \\
\hline Observations & 2,597 & 2,036 & 4,633 \\
\hline
\end{tabular}

${ }^{* * *} \mathrm{p}<0.01,{ }^{* *} \mathrm{p}<0.05,{ }^{*} \mathrm{p}<0.1$

The equivalent of regression (4) in Table A. 3 could not be estimated because of insufficient data. 
Table IV.4.6: Decrease in Bids, Tail Losses, Autocorrelation, Hope and Fear. Panel linear regressions with AR(1) error terms and random effects and robust standard errors clustered at the individual levels in parentheses, session fixed effects included.

\begin{tabular}{|c|c|c|c|c|}
\hline VARIABLE & \multicolumn{4}{|c|}{ UP DUMMY } \\
\hline $\begin{array}{l}\text { SAMPLE } \\
\text { (Investors bought asset in previous period) }\end{array}$ & $\begin{array}{l}\text { (1) } \\
\text { Hopeful \& Not } \\
\text { fearful }\end{array}$ & $\begin{array}{l}\text { (2) } \\
\text { Fearful \& Not } \\
\text { Hopeful }\end{array}$ & (3) & $\begin{array}{l}(4) \\
\text { High Availabil- } \\
\text { ity Bias }\end{array}$ \\
\hline Tail Event Dummy & $\begin{array}{l}-0.254^{* *} \\
(0.126)\end{array}$ & $\begin{array}{l}-0.002 \\
(0.152)\end{array}$ & $\begin{array}{l}-0.013 \\
(0.143)\end{array}$ & $\begin{array}{l}0.031 \\
(0.235)\end{array}$ \\
\hline Hopeful Dummy & - & - & $\begin{array}{l}-0.086^{*} \\
(0.047)\end{array}$ & $\begin{array}{l}-0.183^{* * *} \\
(0.053)\end{array}$ \\
\hline Feedback Arousal Dummy & $\begin{array}{l}0.001 \\
(0.017)\end{array}$ & $\begin{array}{l}0.024 \\
(0.022)\end{array}$ & $\begin{array}{l}0.026 \\
(0.020)\end{array}$ & $\begin{array}{l}-0.013 \\
(0.032)\end{array}$ \\
\hline Tail Event $\times$ Feedback Arousal Dummy & $\begin{array}{l}0.417^{* * *} \\
(0.160)\end{array}$ & $\begin{array}{l}0.141 \\
(0.206)\end{array}$ & $\begin{array}{l}0.148 \\
(0.193)\end{array}$ & $\begin{array}{l}-0.510 \\
(0.323)\end{array}$ \\
\hline Tail Event $\times$ Hopeful Dummy & - & - & $\begin{array}{l}-0.236 \\
(0.196)\end{array}$ & $\begin{array}{l}-0.283 \\
(0.273)\end{array}$ \\
\hline Feedback Arousal $\times$ Hopeful Dummy & - & - & $\begin{array}{l}-0.026 \\
(0.027)\end{array}$ & $\begin{array}{l}0.009 \\
(0.041)\end{array}$ \\
\hline Tail Event $\times$ Feedback Arousal $\times$ Hopeful Dummy & - & - & $\begin{array}{l}0.266 \\
(0.258)\end{array}$ & $\begin{array}{l}0.738^{*} \\
(0.382)\end{array}$ \\
\hline Number of Tail Events & $\begin{array}{l}-0.011 \\
(0.013)\end{array}$ & $\begin{array}{l}-0.005 \\
(0.016)\end{array}$ & $\begin{array}{l}-0.009 \\
(0.010)\end{array}$ & $\begin{array}{l}-0.005 \\
(0.014)\end{array}$ \\
\hline Constant & $\begin{array}{l}0.141 \\
(0.116)\end{array}$ & $\begin{array}{l}0.256^{* * *} \\
(0.074)\end{array}$ & $\begin{array}{l}0.261^{* * *} \\
(0.073)\end{array}$ & $\begin{array}{l}0.300^{* * *} \\
(0.065)\end{array}$ \\
\hline Observations & 3,174 & 2,557 & 5,731 & 3,026 \\
\hline Number of investors & 29 & 21 & 50 & 28 \\
\hline
\end{tabular}

${ }^{* * *} \mathrm{p}<0.01,{ }^{* *} \mathrm{p}<0.05,{ }^{*} \mathrm{p}<0.1$ 
Table IV.4.7: Decrease in Bids, Tail Losses, No Bankruptcy, Hope and Fear. Panel probit regressions with random effects and robust standard errors clustered at the individual levels in parentheses, session fixed effects included.

\begin{tabular}{|c|c|c|c|c|}
\hline \multirow[b]{2}{*}{$\begin{array}{l}\text { VARIABLE } \\
\text { SAMPLE } \\
\text { (Investors bought asset in previous period \& ob- } \\
\text { served less than two tail events) }\end{array}$} & \multicolumn{4}{|c|}{ UP DUMMY } \\
\hline & $\begin{array}{l}\text { (1) } \\
\text { Hopeful \& Not } \\
\text { fearful }\end{array}$ & $\begin{array}{l}\text { (2) } \\
\text { Fearful \& Not } \\
\text { Hopeful }\end{array}$ & (3) & $\begin{array}{l}(4) \\
\text { High Availabil- } \\
\text { ity Bias }\end{array}$ \\
\hline Tail Event Dummy & $\begin{array}{l}-4.758^{\star * *} \\
(0.148)\end{array}$ & $\begin{array}{l}-0.190 \\
(0.640)\end{array}$ & $\begin{array}{l}-0.231 \\
(0.637)\end{array}$ & $\begin{array}{l}-5.121^{\star * *} \\
(0.194)\end{array}$ \\
\hline Hopeful Dummy & - & - & $\begin{array}{l}-0.330 \\
(0.257)\end{array}$ & $\begin{array}{l}-0.733^{\star * *} \\
(0.268)\end{array}$ \\
\hline Feedback Arousal Dummy & $\begin{array}{l}-0.124 \\
(0.093)\end{array}$ & $\begin{array}{l}0.036 \\
(0.060)\end{array}$ & $\begin{array}{l}0.010 \\
(0.060)\end{array}$ & $\begin{array}{l}-0.105 \\
(0.126)\end{array}$ \\
\hline Tail Event $\times$ Feedback Arousal Dummy & $\begin{array}{l}5.205^{* * *} \\
(0.540)\end{array}$ & $\begin{array}{l}0.106 \\
(0.989)\end{array}$ & $\begin{array}{l}0.153 \\
(0.957)\end{array}$ & $\begin{array}{l}-0.032 \\
(0.321)\end{array}$ \\
\hline Tail Event $\times$ Hopeful Dummy & - & - & $\begin{array}{l}-4.573^{* * *} \\
(0.654)\end{array}$ & $\begin{array}{l}0.208 \\
(0.249)\end{array}$ \\
\hline Feedback Arousal $\times$ Hopeful Dummy & - & - & $\begin{array}{l}-0.120 \\
(0.109)\end{array}$ & $\begin{array}{l}0.018 \\
(0.157)\end{array}$ \\
\hline Tail Event $\times$ Feedback Arousal $\times$ Hopeful Dummy & - & - & $\begin{array}{l}5.128^{* * *} \\
(1.095)\end{array}$ & $\begin{array}{l}5.264^{* * *} \\
(0.813)\end{array}$ \\
\hline Period & $\begin{array}{l}-0.002 \\
(0.001)\end{array}$ & $\begin{array}{l}-0.000 \\
(0.001)\end{array}$ & $\begin{array}{l}-0.001 \\
(0.001)\end{array}$ & $\begin{array}{l}-0.000 \\
(0.001)\end{array}$ \\
\hline Number of Tail Events & $\begin{array}{l}0.092 \\
(0.129)\end{array}$ & $\begin{array}{l}-0.004 \\
(0.094)\end{array}$ & $\begin{array}{l}0.038 \\
(0.079)\end{array}$ & $\begin{array}{l}0.106 \\
(0.121)\end{array}$ \\
\hline Constant & $\begin{array}{l}-0.683^{\text {*}} \\
(0.047)\end{array}$ & $\begin{array}{l}-0.847^{\star * *} \\
(0.322)\end{array}$ & $\begin{array}{l}-0.845^{\text {*} ~} \\
(0.317)\end{array}$ & $\begin{array}{l}-0.770^{*} \\
(0.430)\end{array}$ \\
\hline Observations & 2,597 & 2,036 & 4,633 & 2,312 \\
\hline Number of investors & 29 & 21 & 50 & 27 \\
\hline
\end{tabular}

${ }^{* * *} \mathrm{p}<0.01,{ }^{* *} \mathrm{p}<0.05,{ }^{*} \mathrm{p}<0.1$ 
Table IV.4.8: Increase in Bids, Tail Losses, Hope and Emotionality. Panel probit regressions with random effects and robust standard errors clustered at the individual levels in parentheses, session fixed effects included. Emotional (not emotional) investors are those who score above (below) the median on the HEXACO emotionality factor.

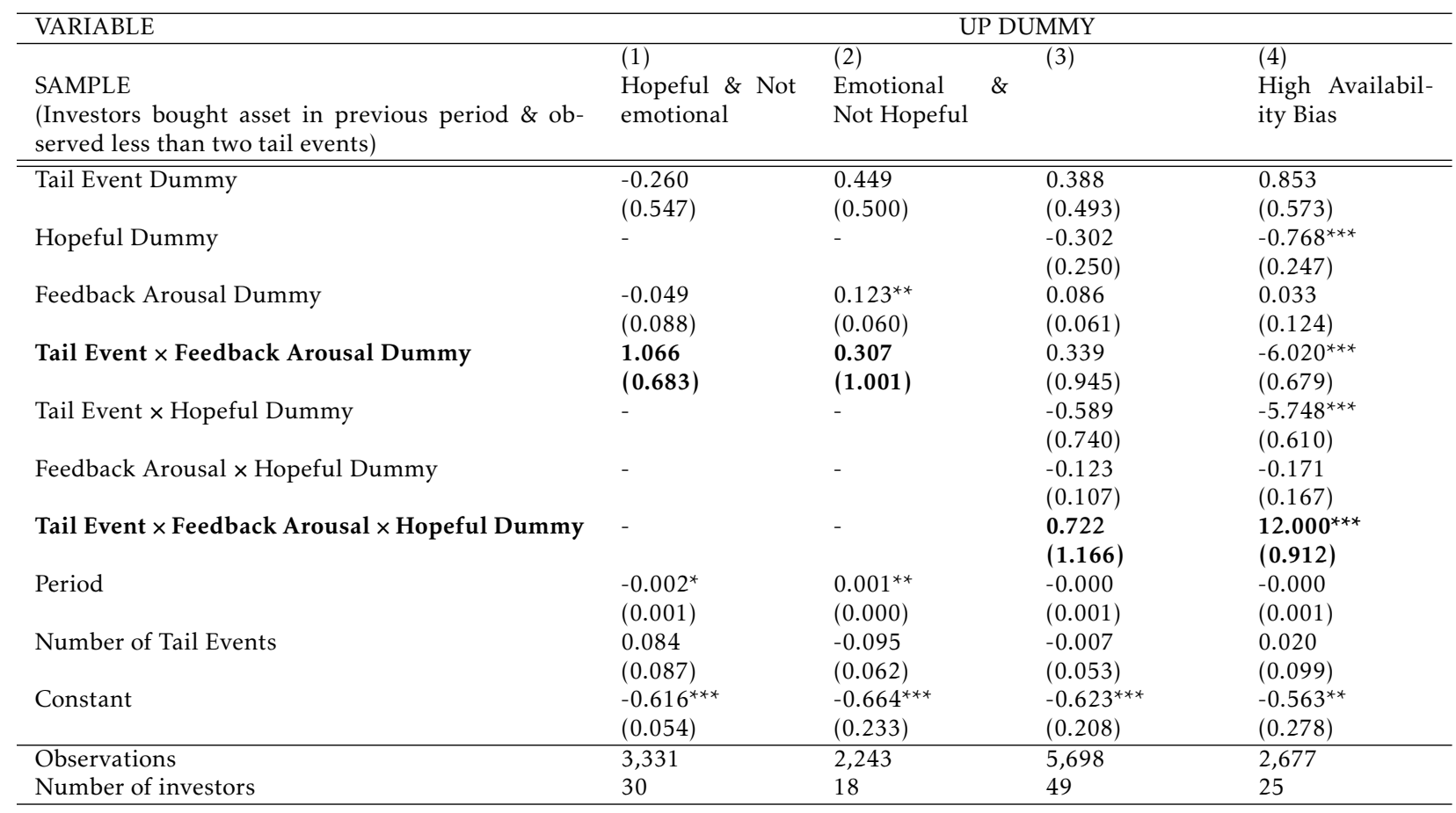

${ }^{* * *} \mathrm{p}<0.01,{ }^{* *} \mathrm{p}<0.05,{ }^{*} \mathrm{p}<0.1$ 


\section{Non-parametric tests}

We tested our main results using non-parametric tests.

\section{V.1 Hypothesis 1}

As a simple check for Hypothesis 1, we computed for each participant the average value by which they changed their bids in a given period after observing, yet not suffering, a tail event and after observing a non-tail event. We then conducted a Wilcoxon signed-rank test with all the participants, except for those who never encountered a tail event in the experiment (i.e., $n=80$ ). In line with Hypothesis 1 , we find that investors were more likely to decrease their bids after observing a tail rather than a non-tail event ( $p$-value =0.029).

\section{V.2 Hypothesis 2}

Using a similar procedure, we also find, in line with Hypothesis 2, that investors were more likely to increase their bids after suffering tail losses than after experiencing a non-tail event ( $p$-value $=0.073$ ) and this was especially so for investors who exhibited high loss aversion ( $\mathrm{p}$-value $=0.030$ ).

\section{V.3 Hypothesis 3}

As a simple check for Hypothesis 3, we computed for each participant the average value by which they changed their bids in a given period after suffering a tail event and after experiencing a non-tail event, in the case in which they were emotionally aroused by the event and in the case in which they were not. In line with Table 3, we find that investors who were emotionally aroused by the event were more likely to increase their bids after suffering tail losses than after experiencing a non-tail event ( $\mathrm{p}$-value $=0.065$, and $\mathrm{p}$-value $=0.038$ when considering participants with high loss aversion). This was not the case for participants who were not emotionally aroused by the events $(\mathrm{p}$-value $=0.446$, and $\mathrm{p}$-value $=0.510$ when considering people with high loss aversion). Using a similar procedure, we also find that loss-averse participants were more likely to increase their bids after suffering tail losses than after experiencing a non-tail event when they were anger-prone $(\mathrm{p}$-value $=0.012)$ whereas this was not the case for participants who were not angerprone $(\mathrm{p}$-value $=0.332)$. 


\section{V.4 Hypothesis 4}

We tested Hypothesis 4 using non-parametric tests, although recognizing that we have only few participants who have observed at least one tail event and who are hopeful (yet not fearful) $(n=28)$ and who are fearful (yet not hopeful) $(n=18)$. As a simple check for Hypothesis 4i, we compared how hopeful (yet not fearful) investors changed their bids after observing, yet not suffering, a tail event compared to a nontail event. We find that they were more likely to increase their bids after observing a tail event, although this effect did not reach statistical significance $(\mathrm{p}$-value $=0.117)$. For the case of fearful (yet not hopeful) investors, the same test reported a p-value of 0.600. Regarding Hypothesis 4ii, we conducted similar nonparametric tests for the case in which tail and non-tail events were actually experienced. We found that fearful (yet not hopeful) investors were less likely to increase their bids after observing a tail event (p-value $=0.040$ ). For the case of hopeful (yet not fearful) investors, the same test reported a p-value of 0.836 .

\section{V.5 Hypothesis 5}

Using Wilcoxon rank-sum tests, we confirm that investors who displayed high baseline anticipatory arousal (i.e., 'High Anticipatory Arousal Dummy' equal ones) earned more (p-value $=0.066$ ) and bid lower, although not significantly so, than those who displayed low baseline anticipatory arousal (p-value $=0.143$ ). Because participants faced different distributions of tail events and because of potential selection effects associated with bankruptcies, we also compare average bids before any tail event had yet been observed, in which case investors who displayed high baseline anticipatory arousal posted significantly lower bids than other investors ( $\mathrm{p}$-value $=0.022$ ). Using proportion tests, we also report that investors with high baseline anticipatory arousal suffered less bankruptcies ( $\mathrm{p}$-value $=0.044)$ and were less affected by tail events $(\mathrm{p}$-value $=0.059)$. 